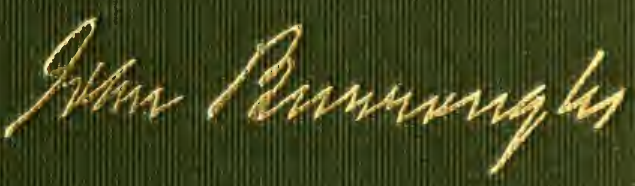




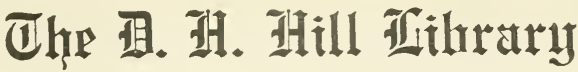

Sirth Caralina State College

$$
\begin{aligned}
& \text { QH81 } \\
& \text { B97 }
\end{aligned}
$$




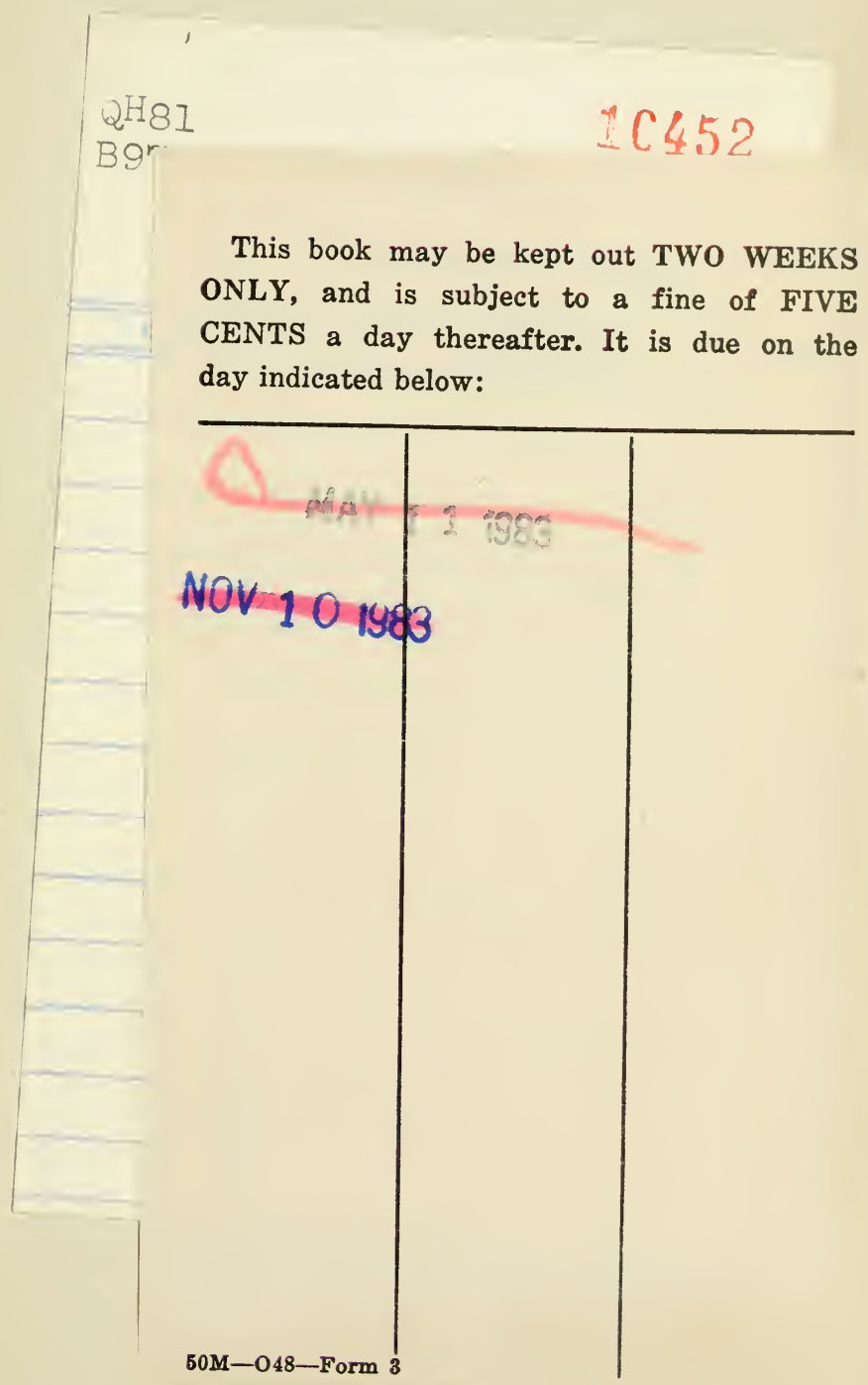





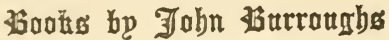

WORKS. 19 vols., uniform, $16 \mathrm{mo}$, with frontispiece, gilt top.

WAKE-ROBIN.

WINTER SUNSHINE.

Locusts and WILD HONEY.

FrRSh FIELDS.

INDOOR STUDIES.

Birds AND POETs, with Other Papers.

Pepacton, and Other Sketches.

Signs and Seasons.

RIVERBY.

WhitMAN : A Study.

The Light OF DAY.

LITBRARY ValUES.

Far aNd NEAR.

WAYS OF NATURE.

LEAF AND TENDRIL.

Time and Change.

Thв SUmmit OF the Years.

'The Breath of Life.

UNDER THE APPLE-TREES.

Fizid and Study.

FIELD AND STUDY. Riverside Edition.

UNDER THE APPLE-TREES. Riverside Edition.

THE BREATH OF LIFE. Riverside Edition.

THE SUMMIT OF THE YEARS, Riverside Edition.

TIME AND CHANGE. Riverside Edition.

LEAF AND TENDRIL. Riverside Edition.

WAYS OF NATURE. Riverside Edition.

FAR AND NEAR. Riverside Edition.

LITERARY VALUES. Riverside Edition.

THE LIGHT OF DAY. Riverside Edition.

WHITMAN: A Study. Riverside Edition.

A YEAR IN THE FIELDS. Selections appropriate to each season of the year, from the writings of John Burroughs. Illustrated from Photographs by CLIFTON JOHNSON.

IN THE CATSKILLS. Illustrated from Photographs by Clifton JoHNSON.

CAMPING AND TRAMPING WITH ROOSEVELT. Illustrated from Photographs.

BIRD AND BOUGH. Poems.

WINTER SUNSHINE. Cambridge Classics Series.

WAKE-ROBIN. Riverside Aldine Series.

SQUIRRELS AND OTHER FUR-BEARERS. Illustrated.

BIRD STORIES FROM BURROUGHS. Illustrated.

HOUGHTON MIFFLIN COMPANY

Boston AND New York 


\section{FIELD AND STUDY}





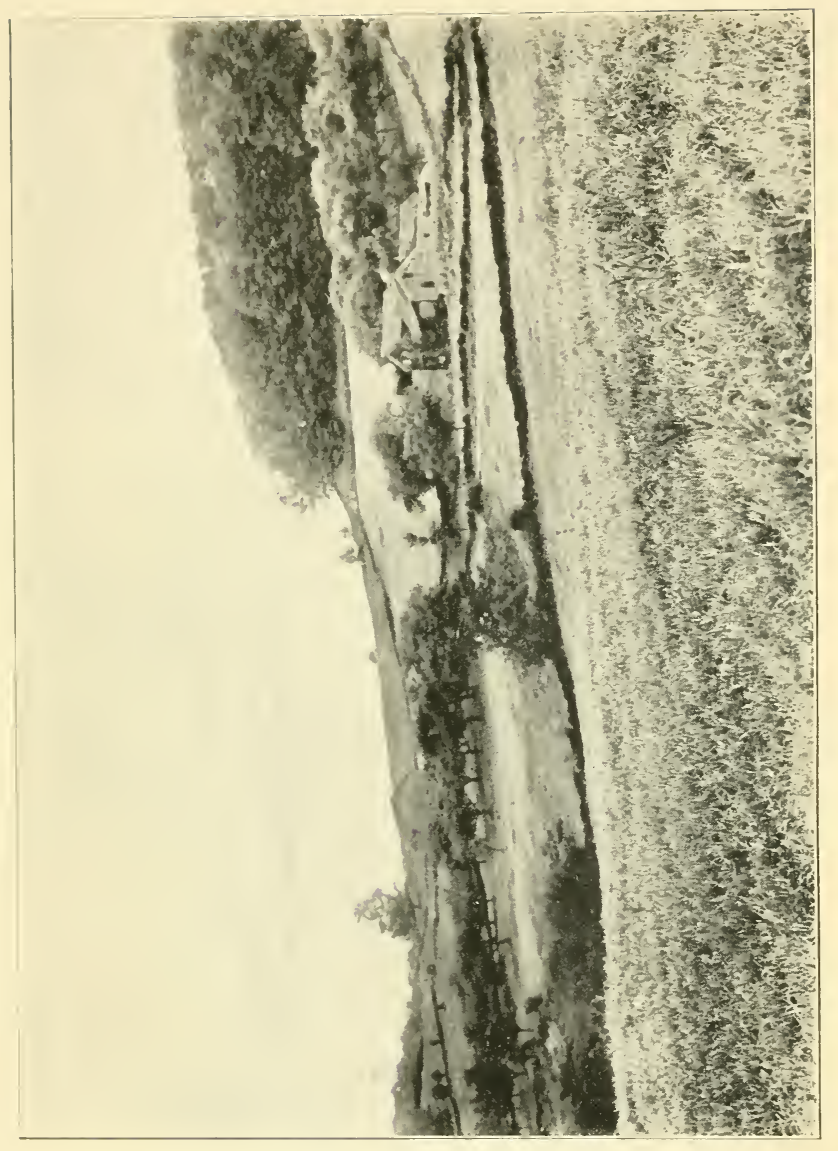




\section{FIELD AND STUDY}

BY

\section{JOHN BURROUGHS}

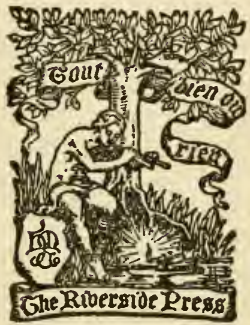

BOSTON AND NEW YORK

HOUGHTON MIFFLIN COMPANY

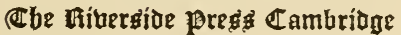


COPYRIGHT, 1919, BY JOHN BURROUGHS

ALL RIGHTS RESERVED 


\title{
CONTENTS
}

\author{
Part I: Afield
}

I. The Spring Bird Procession . . . . 3

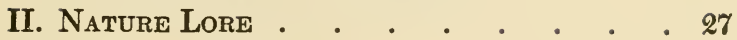

III. The Familiar Birds • . . . . . 53

IV. Fuss and Feathers . . . . . . 77

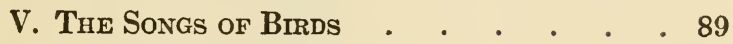

VI. Orchard Secrets . . . . . . . . 102

VII. Nature in Little . • • . . . 112

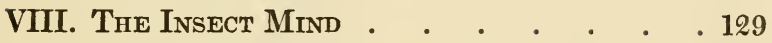

IX. A Clever Beastie . . . . . . . 140

X. Phases of Animal Life . . . 152

XI. EACH After Its Kind . . . . . . 158

XII. The Pleasures of Science • • . 174

XIII. New Gleanings in Old Fields . 193

I. Live Natural History $\quad$ • . 193

II. The Barn Swallow . . . 198

III. INSECTS $\quad \cdot \quad \cdot \quad \cdot \quad \cdot \quad \cdot 201$

IV. The Dog . . • . . . 205

V. Wood WaIfS • • • • • . 206

VI. An Interesting Plant . . . 210

VII. Nature Near Home . . . . 213

\section{Part II: Study Notes}

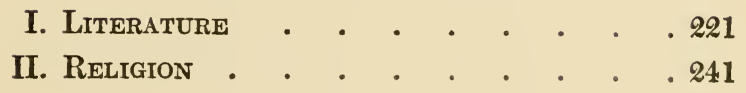




\section{CONTENTS}

III. SCIENCE - • • • . • . . . . 252

IV. Evolution • • • • • • • • • 273

V. Nature and Natural History • • . . 289

VI. Miscellaneous Notes . • • • . . . . 320

INDEX . . . . . . . . . . . 331 


\section{FIELD AND STUDY Part I AFIELD}





\section{FIELD AND STUDY}

Part I: Afield

\section{I \\ THE SPRING BIRD PROCESSION}

NE of the new pleasures of country life when one has made the acquaintance of the birds is to witness the northward bird procession as it passes or tarries with us in the spring - a procession which lasts from April till June and has some new feature daily.

The migrating wild creatures, whether birds or beasts, always arrest the attention. They seem to link up animal life with the great currents of the globe. It is moving day on a continental scale. It is the call of the primal instinct to increase and multiply, suddenly setting in motion whole tribes and races. The first phøebe-bird, the first song sparrow, the first robin or bluebird in March or early April, is like the first ripple of the rising tide on the shore.

In my boyhood the vast armies of the passenger pigeons were one of the most notable spring tokens. Often late in March, or early in April, the naked beechroods would suddenly become blue with 3

\section{H. HILL LIBRARY,} North Carolina State Collega 


\section{FIELD AND STUDY}

them, and vocal with their soft, childlike calls; or all day the sky would be streaked with the long lines or dense masses of the moving armies. The last great flight of them that I ever beheld was on the 10th of April, 1875, when, for the greater part of the day, one could not at any moment look skyward above the Hudson River Valley without seeing several flocks, great and small, of the migrating birds. But that spectacle was never repeated as it had been for generations before. The pigeons never came back. Death and destruction, in the shape of the greed and cupidity of man, were on their trail. The hosts were pursued from State to State by professional pot-hunters and netters, and the numbers so reduced, and their flocking instinct so disorganized, that their vast migrating bands disappeared, and they were seen only in loosely scattered and diminishing flocks in different parts of the West during the remainder of the century. A friend of mine shot a few in Indiana in the early eighties, and scattered bands of them have occasionally been reported, here and there, up to within a few years. The last time that my eyes beheld a passenger pigeon was in the fall of $\mathbf{1 8 7 6}$ when I was out for grouse. I saw a solitary cock sitting in a tree. I killed it, little dreaming that, so far as I was concerned, I was killing the last pigeon.

What man now in his old age who witnessed in youth that spring or fall festival and migration of 


\section{THE SPRING BIRD PROCESSION}

the passenger pigeons would not hail it as one of the gladdest hours of his life if he could be permitted to witness it once more? It was such a spectacle of bounty, of joyous, copious animal life, of fertility in the air and in the wilderness, as to make the heart glad. I have seen the fields and woods fairly inundated for a day or two with these fluttering, piping, blue-and-white hosts. The very air at times seemed suddenly to turn to pigeons.

One May evening recently, near sundown, as I sat in my summer-house here in the Hudson Valley, I saw a long, curved line of migrating fowl high in the air, moving with great speed northward, and for a moment I felt the old thrill that I used to experience on beholding the pigeons. Fifty years ago I should have felt sure that they were pigeons; but they were only ducks. A more intense scrutiny failed to reveal the sharp, arrow-like effect of a swiftly moving flock of pigeons. The rounder, bottle-shaped bodies of the ducks also became apparent. But migrating ducks are a pleasing spectacle, and when, a little later, a line of geese came into my field of vision, and re-formed and trimmed their ranks there against the rosy sky above me, and drove northward with their masterly flight, there was no suggestion of the barnyard or farm pond up there.

"Whither, midst falling dew,

While glow the heavens with the last steps of day, 


\section{FIELD AND STUDY}

Far, through their rosy depths, dost thou pursue Thy solitary way?"

Bryant, by the way, handled natural subjects in a large, free, simple way, which our younger poets never attained.

When one is fortunate enough to see a line of swans etched upon the sky near sunset, a mile or more high, as has been my luck but twice in my life, one has seen something he will not soon forget.

The northward movement of the smaller bodies - the warblers and finches and thrushes - gives one pleasure of a different kind, the pleasure of rare and distinguished visitors who tarry for a few hours or a few days, enlivening the groves and orchards and garden borders, and then pass on. Delicacy of color, grace of form, animation of movement, and often snatches of song, and elusive notes and calls, advise the bird-lover that the fairy procession is arriving. Tiny guests from Central and South America drop out of the sky like flowers borne by the night winds, and give unwonted interest to our tree-tops and roadside hedges. The rubycrowned kinglet heralds the approach of the procession, morning after morning, by sounding his elfin bugle in the evergreens.

The migrating thrushes in passing are much more chary of their songs, although the hermit, the veery, and the olive-backed may occasionally be heard. I have even heard the northern water-thrush sing 


\section{THE SPRING BIRD PROCESSION}

briefly in my currant-patch. The bobolink begins to burst out in sudden snatches of song, high in air, as he nears his northern haunts. I have often in May heard the black-poll warbler deliver his fine strain, like that of some ticking insect, but have never heard the bay-breasted nor the speckled Canada during migration. None of these birds sing or nest in the tropical countries where they pass more than half the year. They are like exiles there; the joy and color fade out of their lives in the land of color and luxuriance. The brilliant tints come to their plumage, and the songs to their hearts, only when the breeding impulse sends them to their brief northern homes. Tennyson makes his swallow say, -

"I do but wanton in the South,

While in the North long since my nest is made."

It is highly probable, if not certain, that the matches made in the North endure but for a season, and that new mates are chosen each spring. The males of most species come a few days in advance of the females, being, I suppose, supercharged with the breeding impulse.

That birds have a sense of home and return in most cases to their old haunts, is quite certain. But whether both sexes do this, or only the males, I have no proof. But I have proof which I consider positive that the male song sparrow returns, and there is pretty good evidence that the same thing 


\section{FIELD AND STUDY}

is true of several, probably of most, other species. A friend of mine has a summer home in one of the more secluded valleys of the Catskills, and every June for three years a pair of catbirds have nested near the house; and every day, many times, one or both birds come to the dining-room window, for sweet butter. Very soon after their arrival they appear at the window, shy at first, but soon becoming so tame that they approach within a few feet of the mistress of the house. They light on the chairbacks and sometimes even hop on the table, taking the butter from the fork held by the mistress. Their behavior now is very convincing that one or both have been at the window for butter in previous years.

Let me quote a page or two from my notebook, under date of May 25:-

Walked down through the fields and woods to the river, and then along the wooded banks toward home.

Redstarts here and there in the woods, going through their pretty gymnastics. None of our insect-feeders known to me so engage the eye. The flashes of color, and the acrobatic feats - how they set each other off! It is all so much like a premeditated display, or a circus, or an operatic performance, that one is surprised to find a solitary bird in the woods so intent upon it. Every movement is accompanied by its own feathered display. The tail, with its bands of black and orange, is as active in opening and shutting as a lady's fan at the opera signaling to her lover; the wings unfold, or droop, and second 


\section{THE SPRING BIRD PROCESSION}

the sensitive tail, and the whole behavior of the bird makes him about the prettiest actor in the little flycatching drama of the season. This behavior would suggest that the bird feeds upon a particular kind of insect; at all times and places it is engaged in the same striking acrobatic feats; just as the black and white creeping warvler is always busy in the hunt for some minute insect on the trunks of trees.

I recall several of our insect-feeders each of which seems to have its own insect province. The Kentucky warbler, where I have known it on the Potomac, fed for the most part on insects which it gathered from the under side of the leaves of certain plants near the ground. Hence it is classed among the ground warblers, like the Maryland yellowthroat. The red-eyed vireo feeds largely on the insects which hide on the under side of leaves in the tree-tops.

When the oriole first comes in May, he is very busy searching into the heart of the apple-tree bloom for some small insect. I have seen Wilson's black-capped warbler doing the same thing. I have seen a score or more of myrtle warblers very active amid the bushes and trees along a stream, snapping up some slow-moving gauzy insect drifting about there. They often festoon the stream with their curving and looping lines of blue and black and yellow.

The feeding-ground of one bird is often an empty 


\section{FIELD AND STUDY}

larder to another kind. I saw a pretty illustration of this fact yesterday. On the wide, smooth space, graded with sharp gravel in front of my neighbor's boathouse, there were three Blackburnian warblers, one male and two females, very much absorbed in hurrying about over the gray surface, picking up some tiny insects which were invisible to my eye. How intent and eager they were! A nuthatch came down the trunk of the elm and eyed them closely; then took to the ground and followed them about for a moment. But evidently he could not make out what the table was spread with, as, after a few seconds, he flew back to the tree and went on with his own quest of food. But the nuthatches will follow the downy woodpeckers through the trees, and the chickadees follow the nuthatches, and the brown creepers follow the chickadees, and each kind appears to find the food it is looking for. Every man to his taste, and every bird to the food that its beak indicates.

I have no idea as to the kind of food that invariably draws the male scarlet tanager to the ground in the ploughed fields at this season; but there they are in pairs or triplets, slowly looking over the brown soil and visible from afar. Yesterday I came upon two on the ground at a wettish place in the woods, demurely looking about them. How they fairly warmed the eye amid their dull and neutral surroundings! 


\section{THE SPRING BIRD PROCESSION}

Season after season, all over the country, the spectacle of scarlet tanagers inspecting the ground in ploughed fields recurs.

This season an unusual number of male rosebreasted grosbeaks have frequented the ground in my vineyards at the same time. Their black-andwhite plumage, with an occasional glimpse of their rose-colored breasts, makes them very noticeable, but not so conspicuous as the tanagers. But their rich, mellow warblings from the tree-tops more than make up to the ear what the eye misses. Strange to say, in my boyhood I never saw or recognized this bird, and few country or farm people, I think, ever discriminate it. Its song is like that of the robin much softened and rounded and more finely modulated, contrasting in this respect with the harder and more midsummery strain of the tanager. The heavy beak of the bird gives him a somewhat Hebraic look.

\section{II}

That birds of a feather flock together, even in migration, is evident enough every spring. When in the morning you see one of a kind, you may confidently look for many more. When, in early May, I see one myrtle warbler, I presently see dozens of them in the trees and bushes all about me; or, if I see one yellow redpoll on the ground, with its sharp chirp and nervous behavior, I look for more. Yes- 


\section{FIELD AND STUDY}

terday, out of the kitchen window, I saw three speckled Canada warblers on the ground in the garden. How choice and rare they looked on the dull surface! In my neighbor's garden or dooryard I should probably have seen more of them, and in his trees and shrubbery as many magnolia and bay-breasted and black-throated blue warblers as in my own; and about his neighbor's place, and his, and his, throughout the township, and on west throughout the county, and throughout the State, and the adjoining State, on west to the Mississippi and beyond, I should have found in every bushy tangle and roadside and orchard and grove and wood and brookside, the same advancing line of migrating birds - warblers, flycatchers, finches, thrushes, sparrows, and so on - that I found here. I should have found high-holes calling and drumming, robins and phœbes nesting, swallows skimming, orioles piping, oven-birds demurely tripping over the leaves in the woods, tanagers and grosbeaks in the ploughed fields, purple finches in the cherry-trees, and white-throats and white-crowned sparrows in the hedges.

One sees the passing bird procession in his own grounds and neighborhood without pausing to think that in every man's grounds and in every neighborhood throughout the State, and throughout a long, broad belt of States, about several millions of homes, and over several millions of farms, the 


\section{THE SPRING BIRD PROCESSION}

same flood-tide of bird-life is creeping and eddying or sweeping over the land. When the mating or nesting high-holes are awakening you in the early morning by their insistent calling and drumming on your metal roof or gutters or ridge-boards, they are doing the same to your neighbors near by, and to your fellow countrymen fifty, a hundred, a thousand miles away. Think of the myriads of dooryards where the "chippies" are just arriving; of the blooming orchards where the passing manycolored warblers are eagerly inspecting the buds and leaves; of the woods and woody streams where the oven-birds and water-thrushes are searching out their old haunts; of the secluded bushy fields and tangles where the chewinks, the brown thrashers, the chats, the catbirds, are once more preparing to begin life anew - think of all this and more, and you may get some idea of the extent and importance of our bird-life.

I fancy that on almost any day in mid-May the flickers are drilling their holes into a million or more decayed trees between the Hudson and the Mississippi; that any day a month earlier the phobes are starting their nests under a million or more woodsheds or bridges or overhanging rocks; that several millions of robins are carrying mud and straws to sheltered projections about buildings, or to the big forked branches in the orchards.

When in my walk one day in April, through an 


\section{FIELD AND STUDY}

old cedar lane, I found a mourning dove's nest on the top of an old stone wall, - the only one I ever found in such a position, - I wondered how many mourning doves throughout the breadth and length of the land had built or were then building their nests on stone walls or on rocks.

Considering the enormous number of birds of all species that flood the continent at this season, as if some dike or barrier south of us had suddenly given way, one wonders where they could all have been pent up during the winter. Mexico and Central and South America have their own bird populations the seasons through; and with the addition of the hosts from this country, it seems as if those lands must have literally swarmed with birds, and that the food question (as with us) must have been pressing. Of course, a great many of our birds such as sparrows, robins, blackbirds, meadowlarks, jays, and chewinks - spend the winter in the Southern States, but many more - warblers, swallows, swifts, hummers, orioles, tanagers, cuckoos, flycatchers, vireos, and others - seek out the equatorial region.

III

The ever-memorable war spring of 1917 was very backward, - about two weeks later than the average, - very cold, and very wet. Few fruit-trees bloomed before the 20th of May; then they all 


\section{THE SPRING BIRD PROCESSION}

bloomed together: cherry, pear, peach, apple, all held back till they could stand it no longer. Pink peach-orchards and white apple-orchards at the same time and place made an unusual spectacle.

The cold, wet weather, of course, held up the bird procession also. The warblers and other migrants lingered and accumulated. The question of food became a very serious one with all the insect-eaters. The insects did not hatch, or, if they did, they kept very close to cover. The warblers, driven from the trees, took to the ground. It was an unusual spectacle to see these delicate and many-colored spirits of the air and of the tree-tops hopping about amid the clods and the rubbish, searching for something they could eat. They were like jewels in the gutter, or flowers on the sidewalk.

For several days in succession I saw several speckled Canada warblers hopping about my newly planted garden, evidently with poor results; then it was two or more Blackburnian warblers looking over the same ground, their new black-and-white and vivid orange plumage fairly illuminating the dull surface. The redstarts flashed along the ground and about the low bushes and around the outbuildings, delighting the eye in the same way. Baybreasted warblers tarried and tarried, now on the ground, now in the lower branches of the trees or in bushes. I sat by a rapid rocky stream one afternoon and watched for half an hour a score or more 


\section{FIELD AND STUDY}

of myrtle warblers snapping up the gauzy-winged insects that hovered above the water in the fitful sunshine. What loops and lines of color they made, now perched on the stones, now on the twigs of the overhanging trees, now hovering, now swooping! What an animated scene they presented! They had struck a rare find and were making the most of it.

On other occasions I saw the magnolia and Cape May and chestnut-sided warblers under the same stress of food-shortage searching in unwonted places. One bedraggled and half-starved female magnolia warbler lingered eight or ten days in a row of Japanese barberry-bushes under my window, where she seemed to find some minute and, to me, invisible insect on the leaves and in the blossoms that seemed worth her while.

This row of barberry-bushes was the haunt for a week or more of two or three male ruby-throated hummingbirds. Not one female did we see, but two males were often there at the same time, and sometimes three. They came at all hours and probed the clusters of small greenish-yellow blossoms, and perched on the twigs of intermingled lilacs, often remaining at rest five or six minutes at a time. They chased away the big queen bumble-bees which also reaped a harvest there, and occasionally darted spitefully at each other. The first day I saw them, they appeared to be greatly fatigued, as if they had just made the long journey from Central 


\section{THE SPRING BIRD PROCESSION}

America. Never before had I seen this bird-jewel of omnipotent wing take so kindly and so habituatedly to the perch.

The unseasonable season, no doubt, caused the death of vast numbers of warblers. We picked up two about the paths on my place, and the neighbors found dead birds about their grounds. Often live birds were so reduced in vitality that they allowed the passer-by to pick them up. Where one dead bird was seen, no doubt hundreds escaped notice in the fields and groves. A bird lives so intensely - rapid breathing and high temperature - that its need for food is always pressing. These adventurous little aviators had come all the way from South and Central America; the fuel-supply of their tiny engines was very low, and they suffered accordingly.

A friend writing me from Maine at this time had the same story of famishing warblers to tell. Certain of our more robust birds suffered. A male oriole came under my window one morning and pecked a long time at a dry crust of bread - a food, I dare say, it had never tasted before. The robins alone were in high feather. The crop of angleworms was one hundred per cent, and one could see the robins "snaking" them out of the ground at all hours.

Emerson is happy in his epithet "the punctual birds." They are nearly always here on time - always, considering the stage of the season; but the inflexible calendar often finds them late or early. 


\section{FIELD AND STUDY}

There is one bird, however, that keeps pretty close to the calendar. I refer to the white-crowned sparrow, the most distinguished-looking of all our sparrows. Year after year, be the season early or late, I am on the lookout for him between the 12th and the 16th of May. This year, on the 13th, I looked out of my kitchen window and saw two males hopping along side by side in the garden. Unhurriedly they moved about, unconscious of their shapely forms and fine bearing. Their black-and-white crowns, their finely penciled backs, their pure ashengray breasts, and their pretty carriage, give them a decided look of distinction. Such a contrast to our nervous and fidgety song sparrow, bless her little heart! And how different from the more chunky and plebeian-looking white-throats - bless their hearts also for their longer tarrying and their sweet, quavering ribbon of song! The fox sparrow, the most brilliant singer of all our sparrows, is an uncertain visitor in the Hudson River Valley, and seasons pass without one glimpse of him.

The spring of 1917 was remarkable for the number of migrating blue jays. For many days in May I beheld the unusual spectacle of processions of jays streaming northward. Considering the numbers I saw during the short time in the morning that I was in the open, if the numbers I did not see were in like proportion, many thousands of them must have passed my outlook northward. The jay is evidently 


\section{THE SPRING BIRD PROCESSION}

more or less a migrant. I saw not one here during the winter, which is unusual. As one goes south in winter the number of jays greatly increases, till in Georgia they are nearly as abundant as robins are here in summer.

In late April a friend wrote me from a town in northern New York that the high-holes disturbed his sleep in the early morning by incessant drumming on the metal roofs and gutters and ridgeboards. They were making the same racket around us at the same hour. Early in the month a pair of them seem to have been attracted to a cavity in the mid-top of a maple-tree near the house, and the male began to warm up under the fever of the nesting-impulse, till he made himself quite a nuisance to sleepers who did not like to be drummed out before five o'clock in the morning. How loudly he did publish and proclaim his joy in the old command which spring always reaffirms in all creatures! With call and drum, repeated to the weariness of his less responsive neighbors, he made known the glad tidings from his perch on the verge of the tin roof; he would send forth the loud, rapid call, which, as Thoreau aptly says, has the effect as of some one suddenly opening a window and calling in breathless haste, "Quick, quick, quick, quick!" Then he would bow his head and pour a volley of raps upon the wood or metal, which became a continuous stream of ringing blows. One would have thought 


\section{FIELD AND STUDY}

that he had a steel punch for a bill, and that it never got dull.

But the high-hole's bill is a wonderful instrument and serves him in many ways. In the spring birdorchestra he plays an important part, more so than that of any other of the woodpeckers. He is never a disturber of the country quiet except on such occasions as above referred to. His insistent call coming up from the April and May meadows or pastures or groves is pleasing to the nature-lover to a high degree. It does seem to quicken the season's coming, though my pair were slow in getting down to business, doubtless on account of the backward spring and the consequent scarcity of ants, which are their favorite food.

When on the 1st of June I looked into the cavity in one of my maples, and saw only one egg, I thought it a meagre result for all that month and a half of beating of drum and clashing of cymbals; but on the 20th of June the results were more ample, and four open mouths greeted me as I again looked into the little dark chamber in the maple. The drumming and trumpeting had ceased, and the festive and holiday air of the birds had given place to an air of silent solicitude. As the cavity is a natural one, the result of a decayed limb, it does not have the carpeting of soft pulverized "dozy" wood that it would have had it been excavated by the birds. Hence, for days before the full complement of eggs 


\section{THE SPRING BIRD PROCESSION}

was laid, and after the young had hatched, I used to see and hear, as I passed by, one of the parent birds pecking on the sides of the cavity, evidently to loosen material to supply this deficiency.

The high-hole is our most abundant species of woodpecker, and as he gets most of his living from the ground instead of from the trees, he is a migrant in the Northern States. Our other members of the family are mostly black, white, and red, but the high-hole is colored very much like the meadowlark, in mottled browns and whites and yellows, with a dash of red on the nape of his neck. To his enemies in the air he is not a conspicuous object on the ground, as the other species would be.

\section{IV}

The waves of bird migrants roll on through the States into Canada and beyond, breaking like waves on the shore, and spreading their contents over large areas. The warbler wave spends itself largely in the forests and mountains of the northern tier of States and of Canada; its utmost range, in the shape of the pileolated warbler (the Western form of Wilson's black-cap) and a few others, reaching beyond the Arctic Circle, while its content of ground warblers, in the shape of the Maryland yellow-throat and the Kentucky and the hooded warblers, begins to drop out south of the Potomac and in Ohio. 


\section{FIELD AND STUDY}

The robins cover a very wide area, as do the song sparrows, the kingbirds, the vireos, the flickers, the orioles, the catbirds, and others. The area covered by the bobolinks is fast becoming less and less, or at least it is moving farther and farther north. Bobolinks in New York State meadows are becoming rare birds, but in Canadian meadows they appear to be on the increase. The mowing-mactine and the carlier gathering of the hay-crop by ten or fourteen days than fifty years ago probably account for it.

As the birds begin to arrive from the South in the spring, the birds that have come down from the North to spend the winter with us - the crossbills, the pine grosbeaks, the pine linnets, the red-breasted nuthatches, the juncos, and the snow buntings begin to withdraw. The ebb of one species follows the flow of another. One winter, in December, a solitary red-breasted nuthatch took up his abode with me, attracted by the suet and nuts I had placed on a maple-tree-trunk in front of my study window for the downy woodpecker, the chickadees, and the native nuthatches. Red-breast evidently said to himself, "Needless to look farther." He took lodgings in a wren-box on a post near by, and at night and during windy, stormy days was securely housed there. He tarried till April, and his constancy, his pretty form, and his engaging ways greatly endeared him to us. The pair of white-breasted nut- 


\section{THE SPRING BIRD PROCESSION}

hatches that fed at the same table looked coarse and common beside this little delicate waif from the far North. He could not stand to see lying about a superabundance of cracked hickory-nuts, any more than his larger relatives could, and would work industriously, carrying them away and hiding them in the woodpile and summer-house near by. The other nuthatches bossed him, as they in turn were bossed by Downy, and as he in turn bossed the brown creeper and the chickadees. In early April my little red-breast disappeared, and I fancied him turning his face northward, urged by a stronger impulse than that for food and shelter merely. He was my tiny guest from unknown lands, my baby bird, and he left a vacancy that none of the others could fill.

The nuthatches are much more pleasing than the woodpeckers. Soft-voiced, soft-colored, gentle-mannered, they glide over the rough branches and the tree-trunks with their boat-shaped bodies, going up and down and around, with apparently an extra joint in their necks that enables them, head-downward, to look straight out from the tree-trunk; their motions seem far less mechanical and angular than those of the woodpeckers and the creepers. Downy can back down a tree by short hitches, but he never ventures to do it headfirst, nor does the creeper; but the universal joint in the nuthatch's body and its rounded keel enable it to move head on indif- 


\section{FIELD AND STUDY}

ferently in all directions. Its soft nasal call in the spring woods is one of the most welcome of sounds. It is like the voice of children, plaintive but contented, a soft interrogation in the ear of the sylvan gods. What a contrast to the sharp, steely note of the woodpeckers - the hairy's like the metallic sounds of the tinsmith and Downy's a minor key of the same!

But the woodpeckers have their drums which make the dry limbs vocal, and hint the universal spring awakening in a very agreeable manner. The two sounds together, the childish "Yank, yank," of the nuthatch, and the resonant "Rat-tat-tat" of Downy, are coincident with the stirring sap in the maple trees. The robin, the bluebird, the song sparrow, and the phœbe have already loosened the fetters of winter in the open. It is interesting to note how differently the woodpeckers and the nuthatches use their beaks in procuring their food. Downy's head is a trip-hammer, and he drives his beak into the wood by short, sharp blows, making the chips fly, while the nuthatch strikes more softly, using his whole body in the movement. He delivers a kind of feathered blow on the fragment of nut which he has placed in the vise of the tree's bark. My little redbreast, previously referred to, came down on a nut in the same way, with a pretty extra touch of the flash of his wings at each stroke, as the woodchopper says "Hah!" when sending his axe home. 


\section{THE SPRING BIRD PROCESSION}

If this does not add force to his blows, it certainly emphasizes them in a very pretty manner.

Each species of wild creature has its own individual ways and idiosyncrasies which one likes to note. As I write these lines a male kingbird flies by the apple-tree in which his mate is building a nest, with that peculiar mincing and affected flight which none other of the flycatchers, so far as I know, ever assumes. The olive-sided flycatcher has his own little trick, too, which the others do not have: I have seen his whole appearance suddenly change while sitting on a limb, by the exhibition of a band of white feathers like a broad chalk-mark outlining his body. Apparently the white feathers under the wings could be projected at will, completely transforming the appearance of the bird. He would change in a twinkling from a dark, motionless object to one surrounded by a broad band of white.

It occasionally happens that a familiar bird develops an unfamiliar trait. The purple finch is one of our sweetest songsters and best-behaved birds, but one that escapes the attention of most country people. But the past season he made himself conspicuous with us by covering the ground beneath the cherry-trees with cherry-blossoms. Being hard put to it for food, a flock of the birds must have discovered that every cherry-blossom held a tidbit in the shape of its ovary. At once the birds began to cut out these ovaries, soon making the ground white 


\section{FIELD AND STUDY}

beneath the trees. I grew alarmed for the safety of my crop of Windsors, and tried to "shoo" the birds away. They looked down upon me as if they considered it a good joke. Even when we shot one, to make sure of the identity of the bird, the flock only flew to the next tree and went on with the snipping. Beneath two cherry-trees that stood beside the highway the blossoms drifted into the wagon tracks like snowflakes. I concluded that the birds had taken very heavy toll of my cherries, but it turned out that they had only done a little of the much-needed thinning. Out of a cluster of six or eight blossoms. they seldom took more than two or three, as if they knew precisely what they were about, and were intent on rendering me a service. When the robins and the cedar-birds come for the cherries they are not so considerate, but make a clean sweep. The finches could teach them manners - and morals. 
II

\section{NATURE LORE}

$W_{\text {MERSON in his Journal says, "All facts in }}$ nature interest us because they are deep and not accidental." Facts of nature are undoubtedly of interest to most persons, though whether or not Emerson gives the true reason may be questioned. I would sooner venture the explanation that it is because nature is a sort of outlying province of ourselves. We feel a kinship with her works, and in bird and beast, in tree and flower, we behold the workings of the same life principle that has brought us where we are and relates us to all living things.

Explain the matter as we may, the facts and doings of nature interest us, and our interest is bound to grow as we enlarge our acquaintance with them, - which is about like saying that our interest keeps pace with our interest. But so it is. Water does not taste good to us until we are thirsty. Before we ask questions we must have questions to ask, and before we have questions to ask we must feel an awakened interest or curiosity. Action and reaction go hand in hand; interest begets interest; knowledge breeds knowledge. Once started in pursuit of nature lore, we are pretty sure to keep on. When people ask me, "How shall we teach our children to love 


\section{FIELD AND STUDY}

nature?" I reply: "Do not try to teach them at all. Just turn them loose in the country and trust to luck." It is time enough to answer children's questions when they are interested enough to ask them. Knowledge without love does not stick; but if love comes first, knowledge is pretty sure to follow. I do not know how I first got my own love for nature, but I suppose it was because I was born and passed my youth on the farm, and reacted spontaneously to the natural objects about me. I felt a certain privacy and kinship with the woods and fields and streams long before the naturalist awoke to selfconsciousness within me. A feeling of companionship with Nature came long prior to any conscious desire for accurate and specific knowledge about her works. I loved the flowers and the wild creatures, as most healthy children do, long before I knew there was such a study as botany or natural history. And when I take a walk now, thoughts of natural history play only a secondary part; I suspect it is more to bathe the spirit in natural influences than to store the mind with natural facts. I think I know what Emerson means when he says elsewhere in his Journal that a walk in the woods is one of the secrets for dodging old age. I understand what the poet meant when he sang:-

"Sweet is the lore which Nature brings."

Nature lore - that is it. Not so much a notebook 


\section{NATURE LORE}

full of notes of birds and trees and flowers as a heart warmed and refreshed by sympathetic intercourse and contact with these primal forces. When "the press of one's foot to the earth springs a hundred affections," as Whitman says, then one gets something more precious than exact science. Nature lore is a mixture of love and knowledge, and it comes more by way of the heart than of the head. We absorb it with the air we breathe; it awaits us at the side of the spring when we stoop to drink; it drops upon us from the trees beneath which we fondly linger; it is written large on the rocks and ledges where as boys we prowled about on Sundays, putting our hands in the niches or on the rocky shelves older than Thebes or Karnak, touching carefully the phœbe's mossy nest, with its pearl-white eggs, or noting the spoor of coon or fox, or coming face to face with the oldest inhabitant of the region, who saw the foundations of the hills laid and the valleys scooped out - Geologic Time, whose tent is the gray, overhanging rocks.

Many a walk I take in the fields and woods when I gather no new facts and make no new observations; and yet I feel enriched. I have been for an hour or more on intimate terms with trees and rocks and grass and birds and with "Nature's primal sanities"; the fragrance of the wild things lingers about my mind for days.

Yet the close observation of nature, the training 


\section{FIELD AND STUDY}

of the eye and mind to read her signals, to penetrate her screens, to disentangle her skeins, to catch her significant facts, add greatly to the pleasure of a walk and to life in the country. Natural history is on the wing, and all about us on the foot. It hides in holes, it perches on trees, it runs to cover under the stones and into the stone walls; it soars, it sings, it drums, it calls by day, it barks and prowls and hoots by night. It eats your fruit, it plunders your garden, it raids your henroost, and maybe disturbs your midnight slumbers.

At Woodchuck Lodge the woodchucks eat up my peas and melons and dig under the foundations of my house; the coons come down off the mountain for sweet apples in my orchard. I surprise the foxes among the cows on my early morning walks, or am awakened in the dawn by the hue and cry of the crows over a fox passing near, a little late in getting back to the cover of the woods.

All such things add interest to country life. No wild creature comes amiss, even though it rob your henroost. I sometimes grow tender toward the woodchuck, even though he raids my garden; he is such a characteristic bit of wild nature, creeping about the fields, or sitting upon his haunches to see if danger is near. He is of the earth, earthy, its true offspring, steeped in its savors, hugging it close, harmonizing with its soil and rocks, almost as liquid as its fountains and as perennial as its grass. 


\section{NATURE LORE}

I even get reconciled to the unsavory but gentlemannered skunk. He does not disturb me if I do not disturb him, and if he chances to get into a trap which I have set for some other animal, his composure is great, and he looks the injured innocent that he is. Only I must keep my eye upon that tail when it starts to rise over his back. There is a masked battery there the noiseless shot of which is usually well aimed, and is pretty sure to rout the foe whether it hit the mark or not. Last summer the morning light revealed one held by the leg in a steel trap which I had set for rats that were helping themselves too freely to my roasting-ears. How sorry and deprecatory he looked as I approached, slowly straining to pull away from the cruel trap, and turning upon me a half-appealing, half-reproachful look! By imitating his slow, gentle manners, I lifted him and the trap to the mouth of a woodchuck hole, into which he quickly crept, leaving his trap-held foot outside. To release him then was an easy matter.

The skunk is a night prowler, and subsists mainly upon insects and small rodents; but I would not insure the birds' eggs or the young birds that happen to be in his path, though Mr. Seton says his tame skunks do not know how to deal with hen's eggs.

There is no prettier bit of natural history upon four legs than the red fox, especially when you sur- 


\section{FIELD AND STUDY}

prise him in your morning walk, or he surprises you in his. He, too, is a night prowler, but often he does not get home till after sun-up. Early one October morning, as I stood in the road looking out over the landscape, a belated fox jumped over the wall a few yards from me and loped unconcernedly along parallel with the road, then turned and scaled the fence, and crossed the road, and went bounding up the hill toward the woods with a grace and ease impossible to describe. I suppose it was his massive tail held level with his body that helped give the idea of buoyancy. There was no apparent effort, as when the farm dog climbs the hill, but the ease and lightness that goes with floating and winged things. It was indeed a pleasing spectacle, such as I had not seen for many years. This winter the fox-hunter with his hound will be trailing him from mountain to mountain or from valley to valley, and he will drift along over the snow, pausing now and then to harken back along his trail, and reluctantly expose himself to the eye of day in the broad open spaces. Unless the day is wet and his tail and fur get draggled, he will run from sun to sun without much apparent fatigue. But if his burden gets too great, he knows of holes in the rocks where he can take refuge.

Any device that a plant or an animal has for getting on in the world interests us; it brings the lower orders nearer to us. We have our own devices and 


\section{NATURE LORE}

makeshifts, and we like to know how it is with our near or distant kin among the humbler orders. They are ourselves not yet come to consciousness and to the elective franchise. When the burr of the burdock, reaching forth its arms for such a chance, seizes on to your coat-tail, take your pocket-glass and examine the minute hooks that tip the ends of the seed-scales. They fish for you and your dog and sheep and cow, and they catch you, not with one hook, but with twenty or fifty, all at the same time. But in this case it is not the fish that is caught, but the fisherman. The plan of this fisherman is to go right along with his captor, the farther the better, and plant his progeny in a new territory. He lets go his hold upon the parent plant at a mere touch, but the touch gives him all the hold he wants. The hooks are fine and hard, like minute, sharp horns, not too much bent, - that would defeat the end, and perfectly smooth and finished. Instead of hooks, the weed called "bidens" has the teeth or prongs armed with barbs like a fish-hook, many of them on each prong. They are quite as sure a trap as the hooks of the burdock. Nature never fails to perfect her device. Natural selection attends to that. Her traps, her wings, her springs, her balloons, always work. The wings of the maple keys, the ash, and the linden are all different, but they all work.

Nature seems partial to the burdock. What extra pains she seems to have taken to perpetuate this 


\section{FIELD AND STUDY}

worse than useless plant! So far as I know, nothing wants it or profits by it, though I have heard that the petioles when cooked suggest salsify. It is an Ishmaelite among plants. Every man's hand is against it, and nearly every animal has reason to detest it. Against their wills they are engaged in sowing its seeds. The other day I found some burrs matted on the tail of a woodchuck. Birds have been found trapped by its hooks. Apparently the only domestic animal that it does not seize hold of is the pig; the stiff, smooth bristles of the pig afford it a scant hold. It possesses more original sin than any other plant I know. How it drives its roots into the ground, defying your spading-fork! How it seems to drive its burrs into your garments, or into the hair of animals, refusing to let go till it is fairly torn in pieces! See the dog biting them out of his hair with a kind of contemptuous fury. If you try to help him, you must proceed very carefully and deliberately or he will confound you with the burdock and threaten the hand that seeks to aid him. The burdock is vicious to the last, the old burr clings with the same dogged determination as the new. As a noxious weed it is a great success. Discourage it by cutting it down you cannot. By hook or by crook it is bound to persist. Its juice is bitter and its fibre coarse. What a pity that so much native grit and enterprise cannot be turned to some good account! The burrs are detached from the 


\section{NATURE LORE}

parent stem almost as easily as are the quills from the porcupine. Even while it is yet in bloom the hooks will seize your coat-tails and the burr let go its hold upon the stalk. The hooks are not attached to the separate seeds, but are for the burrs as a whole.

I know of no plant so difficult to prevent seeding. Cut it down in July, and in August it has new shoots loaded with burrs; cut these off, and in late September, or early October, it will evolve burrs directly from the stub of the old stalk, often in clusters and bunches, without a leaf to mother them.

The plant if unhindered grows three or four feet high and bears about five hundred burrs, which usually have twelve seeds each, or six thousand seeds to the plant. Before the seeds are ripe they are nearly the size and color of rye or peeled oats. Later they shrink and turn dark. So far as I know, nothing feeds upon them, save the larvæ of some insect. I have examined many burrs in October and found a small white grub in a single seed in each of them. Those good people who fancy that everything was made for some special service to man, would have trouble, I think, to find the uses of the burdock.

The advantage of that array of eager hooks to the burdock (there are more than two hundred of them on each burr) seems obvious, and yet here is the yellow dock alongside of it, a relative of our buckwheat, that has no hooks or other devices that 


\section{FIELD AND STUDY}

I can discover for scattering its seed, and yet it appears to compete successfully with its more lusty neighbor. One is about as abundant and troublesome to the gardener as the other. The seeds of the yellow dock are like small, brown, polished buckwheat. I have never seen birds or squirrels eat them, and what secret way they have of keeping up with the burdocks I do not know. The burdock plants itself deeper in the ground, and defies your spadingfork the more successfully.

I have always been curious to know why the birch is the only one among our many forest-trees that seems to have an ambition to plant itself upon a rock. Other trees do so occasionally, but in the woods I am familiar with I see ten birches upon rocks to one of any other tree. They sit down upon the rock as if it were a chair, and run their big roots off into the ground, apparently entirely at home. How in the first place they get enough foothold in the thin coat of leaf mould that covers the rocks to develop their roots and send them across the barren places and down into the soil is a puzzle. I have seen a small birch sapling that had obtained a foothold in a niche on the side of a cliff send one large root diagonally down across the face of the bare rock two or more yards to the ground, where it took hold and saved the situation. It was like a party going out from a starving camp for relief. To equip and pro- 


\section{NATURE LORE}

vision the party required some resources. "Yes," you may say, "and to know where to send it required some wit." But the roots of a tree always tend downward, as the branches go upward. We are at the end of our tether when we say that such is the rule of nature.

The winged seeds always find their proper habitat, as if they had eyes to see the way. The seeds of the cat-tail flag find the ditches and marshes as unerringly as if they were convoyed. But this intelligence, or self-direction, is only apparent. The wind carries the seeds in all directions, and they fall everywhere, just as it happens, on the hills as well as in the ditches, but only in the latter do they take root and flourish. Nature often resorts to this wholesale method. In scattering pollen and germs by the aid of the wind, this is her method: cover all the ground, and you will be sure to hit your mark night or day.

After one or more windy days in November I am sure to find huddled in the recess of my kitchen door the branching heads of a certain species of wild grass that grows somewhere on the hills west of me. These heads find their ways across fields and highways, over fences, past tree and bushy barriers, down my steps, into the storm-house, and lie there, waiting on the doorsill like things of life, waiting to get into the house. Not one season alone, but every season, they come as punctually as the assessor. 


\section{FIELD AND STUDY}

The watchful broom routs them; but the next day or the next week there they are again, and now and then one actually gets into the kitchen, slipping in between your feet as you open the door. They bring word from over the hills, and the word is: "Sooner or later Nature hits her mark, hits all marks, because her aim is broadcast and her efforts ceaseless. The wind finds every crack and corner. We started on our journey not for your door, but for any door, all doors, any shelter where we could be at rest; and here we are!"

The purple loosestrife travels from marsh to marsh in the Hudson River Valley, and as its seeds are not winged, one may wonder how it gets about so easily. It travels by the aid of wings, but not of its own. Darwin discovered that the seeds of marsh plants are often carried in the mud on the feet of marsh birds. Years ago the loosestrife was in a large marsh six miles south of me. A few years later a few plants appeared in a pond near me, and now this and near-by ponds and marshes are lakes of royal purple in August. The loosestrife in late summer makes such a grand showing with its vast armies of tall, stately plants that one welcomes it to our unsightly marshes.

Only the present season did I observe a peculiar feature of our wild clematis that a little close attention might have shown me at any time: its conspicuous appearance in September, after its flowers 
have faded, which has earned for it the name of "old-man's-beard," is owing to the fact that its seeds have long, feathered tails to aid in their dissemination. It is the only seed I know of that the wind carries by the tail. For some obscure reason it does not carry it very far, or at least does not plant it very successfully, as the clematis is rare with me. Instead of being sown broadcast over the hills and along the fences, it appears sparsely, at wide intervals. It is such a beautiful vine both in flowering-time and seeding-time that one wishes it were more common.

The plants that travel by runners above or below ground are many; the plants that travel by walking are few. I recall only the "walking fern," which now seems to have walked away from my neighborhood, and the black raspberry. Both are slow travelers, but they do reach out and take steps.

Some trees can fight a much more successful battle against browsing animals than can others. The apple and the red thorn are notable examples. Trees like the linden, which the cattle freely crop, are easy victims; they put up no kind of fight. They sprout freely, but they make no headway; their new shoots are swept off every summer, and there the low stool of the tree remains. The beech does better amid grazing cattle, but I doubt if it ever wins the fight. But the apple and the thorn, though the 


\section{FIEI.D AND STUDY}

struggle is a long and hard one, are sure to win in the end; after many years one central shoot gets a start from the top of the thorny mound of cropped twigs, makes rapid strides upward, and in due season stands there the perfected tree. It will now bear fruit for the short-sighted grazers that sought to destroy it.

Our belief in the uniformity of nature, or in the unchangeableness of natural law, is fundamental. We act upon it every hour of our lives; our bodies and minds are built upon that plan. Yet in detail, and within narrow limits, nature is unequal, capricious, incalculable. Can the farmer always foretell his crops or forecast a wet season or a dry? The problem is too complex, or our wits are too shallow.

Last season the hay-crop over a large part of the country broke the record. The meadows everywhere, and without any very obvious reason, doubled their yield; the farmers' barns from Pennsylvania to Maine were bursting with plenty, and at the end of haying a row of stacks encompassed or flanked most of them. The trees all seem to have had a superabundance of leaves. On my own grounds we raked up and put under cover for stable use nearly double the usual quantity from the same number of trees. One important factor in this meadow and pasture and tree fertility was probably the continued deep snows of last winter. About one hundred inches fell in the Hudson Valley, and two feet at one fall in 


\section{NATURE LORE}

December. Snow warms and fertilizes. How it warmed up and quickened the mice beneath it! The meadows yielded double their usual number of meadow mice. Never have I seen in the spring evidence of such a crop. Over a wide area, wherever I looked in meadow bottoms or grassy hillsides or shaven lawns, there were the runways, the grassy nests, the camping-grounds of this vast army of meadow mice. They had evidently had a long picnic. They had had the world under there all to themselves. There had been nothing there to molest or to make them afraid, - no fox, no cat, no owl, no weasel, no mink, - and they had reveled in their freedom and security. One could read it all in the record upon the ground: their straw villages, their round tunnels and sunken runways through the grass, and the marks and refuse everywhere, as of temporary social and holiday gatherings. Vast numbers of bushes and small trees, especially of the apple order, were stripped of their bark to a height of two or more feet from the ground. I even saw a thicket of small young locusts with stems as white as bleached cornstalks. Spring quickly put an end to these winter festivities of the mice and compelled them to take to their old retreats and darkened lives under the ground. Evidently the old mother, in this part of the country at least, took good care of her children last winter, from grass and tree-roots to mice and insects. 


\section{FIELD AND STUDY}

In her subtler physical forces, Nature often seems capricious and lawless, probably on account of our limited vision. We see the lightning cleave the air in one blinding flash from the clouds to the earth, often shattering a tree or a house on its way down. Hence it is always a surprise to see the evidence that the thunderbolt strikes upward as well as downward. During an electric storm one summer night an enormous charge of electricity came up out of the earth under a maple-tree at the foot of the hill below my study, scattering the sod, the roots, and some small bushes like an explosion of powder or dynamite; then it rooted around on the ground like a pig, devouring or annihilating the turf, making a wide, ragged, zigzag trench seven or eight feet long down the hill in the ground, when it dived beneath the wagon track, five or six feet wide, bursting out here and there on the surface, then escaped out of the bank made by the plough on the edge of the vineyard. Here it seems to have leaped to the wire trellis of the grapevines, running along it northward, scorching the leaves here and there, and finally vented its fury on a bird-box that was fastened to a post at the end of the row. It completely demolished the box, going a foot or more out of its way to do so. The box was not occupied, so there was not the anticlimax of a bolt of Jove slaughtering house wrens or bluebirds. Maybe it was the nails that drew the charge to the box. But 


\section{NATURE LORE}

why it was rooting around down the hill when it came out of the ground, instead of leaping upward, is a puzzle. It acted like some blind, crazy material hody that did not know where to go. A cannon-shot would have made a much smoother trench. Its course on the ground was about twelve or fourteen feet, half above and half below ground, and its leap in the air about six feet. Strange that a thing of such incredible speed and power should yet have time to loiter about and do such "fool stunts"! This space-annihilator left a trail like a slow, plodding thing. It burrowed like a mole, it delved like a plough, it leaped and ran like a squirrel, and it struck like a hammer. A spectator would have been aware only of a blinding blaze of fire there on the edge of the vineyard, and heard a crash that would have stunned him; but probably could not have told whether the bolt came upward or downward. Lightning is much quicker than our special senses.

On another occasion, beside my path through the woods to Slabsides, I saw where a bolt had come up out of a chipmunk's hole at the root of a tree, scattered the leaves and leaf mould about, and apparently disappeared in the air.

The lightning seems to have its favorite victims among the trees. I have never known it to strike a beech-tree. Hemlocks and pines are its favorites in my woods. In other regions the oak and the ash re- 


\section{FIELD AND STUDY}

ceive its attention. An oak on my father's farm was struck twice in the course of many years, the last bolt proving fatal. The hard, or sugar, maple, is frequently struck, but only in one instance have I known the tree to be injured. In this case a huge tree was simply demolished. Usually the bolt comes down on the outside of the tree, making a mark as if a knife had clipped off the outer surfaces of the bark, revealing the reddish-yellow interior. In several cases I have seen this effect. But a few summers ago an unusually large and solid sugar maple in my neighbor's woods received a charge that simply reduced it to stovewood. Such a scene of utter destruction I have never before witnessed in the woods. The tree was blown to pieces as if it had been filled with dynamite. Over a radius of fifty or more feet the fragments of the huge trunk lay scattered. It was as if the bolt, baffled so long by the rough coat of mail of the maple, had at last penetrated it and had taken full satisfaction. The explosive force probably came from the instantaneous vaporization of the sap of the tree by the bolt.

Some friends of mine were inoculated with curiosity about insects by watching the transformation of the larvæ of one of the swallow-tailed butterflies, probably the Papilio asterias. As I was walking on their porch one morning in early October I chanced to see a black-and-green caterpillar about two inches long posed in a meditative attitude upon the side 


\section{NATURE LORE}

of the house a foot or more above the floor. The latter half of its body was attached to the board wall, and the fore part curved up from it with bowed head. The creature was motionless, and apparently absorbed in deep meditation. I stooped down and examined it more closely. I saw that it was on the eve of a great change. The surface of the board immediately under the forward part of the body had been silvered over with a very fine silken web that was almost like a wash, rather than something woven. Anchored to this on both sides, as if grown out of the web, ran a very fine thread or cord up over the caterpillar's back, which served to hold it in place; it could lean against the thread as a sailor leans against a rope thrown around him and tied to the mast. With bowed head the future butterfly hung there, and with bowed head I waited and watched. Presently convulsive movements began to traverse its body; through segment after segment a wave of effort seemed to pass. It was a beginning of the travail pains of transformation. Then in a twinkling a slight rent appeared in the skin on the curve of the back, revealing the new light-green surface underneath, the first glimpse of the chrysalis. The butterfly was being born. Slowly, as labor continued, the split in the skin extended down the back and over toward the head till the outlines of the chrysalis became plainly visible. I was witnessing that marvelous transformation in nature of 


\section{FIELD AND STUDY}

a worm into a creature of a much higher and more attractive order; the worm mask was being stripped off, and an embryo butterfly revealed to view. In a few minutes the head and forward part of the body were free, and the latter half was fast becoming so.

The fine silken cord over the back served its purpose well, holding the creature in place while it literally wriggled out of its skin, and when this feat was accomplished, holding it in position for its long winter sleep. The skin behaved as if it were an interested party in the enterprise; much better, I am sure, than one's garments would if one were to try to wriggle out of them without using one's limbs. It folded back, it drew together, it finally became a little pellet or pack of cast-off linen that clung to the tail end of the chrysalis. To effect the final detachment, and not lose the grip which this end seemed to have on the board beneath it, required a good deal of struggling, probably a full minute of convulsive effort before the little bundle of cast-off habiliments let go and dropped, a dark pellet the size of a small pea. Then our insect was at rest, and seemed slowly to contract and stiffen. It had woven itself the silken loop to hold it to its support, and it had struggled out of its old skin on its own initiative or without being mothered or helped, as so many newborn creatures are.

I did not have the pleasure of seeing it spin the cord over the back which plays an important part 


\section{NATURE LORE}

in the process of transformation, mechanical part though it be; but a few days later, through the patient and clear-seeing eyes of my friend Miss Grace Humphrey, I witnessed this operation also. She wrote:-

The day after you left we found another caterpillar, a few feet away from yours. It had already made its saddle-cord and shed its silken robe when we found it, but we watched it change from gray-green to, not greenish-brown at all, but a grayness matching the concrete of the house; for it was higher up than yours, on the ledge below the window, hanging from the ledge against the plaster wall. Its cord, too, apparently grew thicker just at the ends, showing up more plainly for a bit; then like yours it dried up and more perfectly matched its background. In neither of them did the cord continue to look thicker.

The same day I found a third caterpillar under the pear-tree, the very same kind, black with a wide green stripe marking off each segment, and the rows of yellow buttons. I carried it on a leaf up to the porch, where we put it under a glass bowl. But of course it thought that an unfavorable place for housing itself for the winter, and it would n't start, though we kept it there two days. At noon, when freed, it climbed up the wall of the house rather near yours (so they were photographed together), and we held our breaths to see if it would start building operations there. But no. Up the window-ledge it wormed its way, and thence up and up, by the side of the window, leaving all the way along a silky thread, and constantly going back and forth with its head.

Mr. R - knocked it down once to keep it in the sunlight in order to photograph it, and it immediately climbed 


\section{FIELD AND STUDY}

up to the same spot, all the time leaving the white silk thread. It kept climbing up and up till I had to get on a chair to see it, and once I lost my balance and jumped down, jarring it so that I knocked it to the floor. But up it got, and climbed up, and spent the rest of the afternoon alternately wriggling about to find just the right place and making a silken background in one spot. The next day it was still on the window-ledge. About eleven o'clock it disappeared, and I hunted and hunted before I found it on the under side of the porch railing! It was busily making its network, but it made far less than either of the others, and most of the time it was staying quite still. The following day, about noon, it made its cord, anchoring that at one end, then at the other, and going back and forth to strengthen it. When the cord was ready, it put its head through (the cord was made ahead of it) and wriggled itself into the cord; it wriggled fully as hard as when yours got itself out of its striped cover. So slowly and carefully it made its way into place, being most careful not to strain the cord. We watched breathlessly. It pushed itself so far through that it was about half and half, and then it had to wriggle backward till its head and a third of its body was through, and two thirds not through; and wriggling back took far greater care than forward. It stayed just that way, all huddled up for nearly four days, when about eight o'clock in the morning it split and divested itself of its robe. It is matching the brown woodwork like yours, and there all three are!

The incomparable French natural-historian and felicitous writer Henri Fabre has witnessed what I never have: he has seen the caterpillar build its case or cocoon. In the instance which he describes it was 


\section{NATURE LORE}

the small grub of one of the Psyches. The first thing the creature did was to collect bits of felt or pith from the cast-off garment of its mother. These it tied together with a thread of its own silk, forming a band, or girdle, which it put around its own body, uniting the ends. This ring was the start and foundation of the sack in which it was to incase itself. The band was placed well forward, so that the insect could reach its edge by bending its head up and down and around in all directions. Then it proceeded to widen the girdle by attaching particles of down to its edges. As the garment grew toward its head, the weaver crept forward in it, thus causing it to cover more and more of its body till in a few hours it covered all of it, and the sack was complete, a very simple process, and, it would seem, the only possible one. The head, with the flexible neck, which allowed it to swing through the circle, was the loom that did the weaving, the thread issuing from the spinneret on the lip. Did the silk issue from the other end of the body, as we are likely to think it does, the feat would be impossible. I suppose a woman might knit herself into her sweater in the same way by holding the ball of yarn in her bosom and turning the web around and pulling it down instead of turning her body - all but her arms; here she would be balked. To understand how a grub weaves itself a close-fitting garment, closed at both ends, from its own hair, or by what sleight 


\section{FIELD AND STUDY}

of hand it attaches its cocoon to the end of a branch, I suppose one would need to witness the process.

In October these preparations and transformations in the insect world are taking place all about us, and we regard them not. The caterpillars are getting ready for a sleep out of which they awaken in the spring totally different creatures. They tuck themselves away under stones or into crevices, they hang themselves on bushes, they roll themselves up in dry leaves, and brave the cold of winter in tough garments, woolly or silky, of their own weaving. Some of them, as certain of the large moths, do what seems like an impossible stunt: they shut themselves up inside a tough case, or receptacle, and attach it by a long, strong bit of home-made tape to the end of a twig, so that it swings freely in the wind. I have seen the downy woodpecker trying to break into one of these sealed-up, living tombs without avail. Its free, pendent position allows it to yield to the strokes of the bird, and all efforts to penetrate the case are in vain.

How the big, clumsy worm, without help or hands, wove itself into this bird-proof case, and hung itself up at the end of a limb, would be a problem worth solving. Of course it had its material all within its own body, so is not encumbered with outside tools or refractory matter. It was the result of a mechanical and a vital process combined. The creature knew how to use the means which Nature had given 


\section{NATURE LORE}

it for the purpose. Some of the caterpillars weave the chrysalis-case out of the hairs and wool of their summer coats, others out of silk developed from within.

On October mornings I have had great pleasure in turning over the stones by the roadside and lifting up those on the tops of the stone walls and noting the insect-life preparing its winter quarters under them. The caterpillars and spiders are busy. One could gather enough of the white fine silk from spider tents and cocoons to make a rope big enough to hang himself with. The jumping spider may be found in his closely woven tent. Look at his head through a pocket-glass, and he looks like a miniature woodchuck. His smooth, dark-gray, hairy pate and two beadlike eyes are very like; but his broad, blunt nose is unlike. It seems studded with a row of five or six jewels; but these jewels are eyes. What extra bounty Nature seems to have bestowed upon some of these humble creatures! We find our one pair of eyes precious; think what three or four pairs would be if they added to our powers of vision proportionately! But probably the many-eyed spiders and the flies with their compound eyes see less than we do. This multitude of eyes seems only an awkward device of Nature's to make up for the movable eye like our own.

In some of the spiders' cocoons under the stones on the tops of the walls you will find masses of small pink eggs, expected to survive the winter, I suppose, 


\section{FIELD AND STUDY}

and hatch out in the spring. The under side of a stone on the top of a stone wall seems like a very cold cradle and nursery, but the caterpillars in their shrouds survive here, and may not the spiders' eggs?

In October you will find the caterpillars in all stages of making ready for winter. They first cover a small space on the stone upon which they rest with a very fine silken web; it looks like a delicate silver wash. This is the foundation of the coming cocoon, but I could never catch any of them in the act of weaving their cocoons. I brought one to the house and kept it under observation for several days, but it was always passive whenever I glimpsed it through the crack between the stones. The nights were frosty and the days chilly, but some time during the twenty-four hours the creature's loom was at work. One morning a thin veil of delicate silver threads, through which I could dimly see the worm, united the two stones. It seemed to be in the midst of a little thicket of vertical, shining silken threads. It was like some enchantment. A little later the thicket, or veil, had developed into a thin cradle in which lay the chrysalis and the cast-off skin of the worm. This caterpillar had been disturbed a good deal and made to waste some of its precious silk, so that its cocoon was finally a thin, poor one. "Life under a stone" forms a chapter in Nature's infinite book of secrecy which most persons skip, but which is well worth perusal. 


\section{III}

\section{THE FAMILIAR BIRDS}

T CALL the birds familiar in the sense that they 1 make themselves very much at home with us, and not in the sense that their lives become an old story and fail to arouse our interest. It is a story perpetually retold, with endless variations. After you have named them all and have made yourself acquainted with their various characters and habits, your next walk to the fields and woods or along the highway or about your own dooryard may reveal some new trait in finch or thrush, or some significant incident in their lives that kindles your interest afresh.

The birds are pioneers that begin the world anew about us each season, and their lives touch and cross ours at new points at all times. They are always the same familiar birds, the birds of our youth, but they are new as the flowers are new, as the spring and summer are new, as each morning is new. Like Nature herself they are endowed with immortal youth, and always present to us an endless field for fresh observation.

The first robin, the first bluebird, the first song sparrow, the first phobe, the first swallow, is an event which we mention to our neighbor, or write 


\section{FIELD AND STUDY}

in our letters to our friends. It is an old story with a new interest. The birds have lived, and we have lived to meet again the old scenes. They bring us once more the assurance of the unfailing return of spring, and the never-ending joy and fecundity of life. Many of them are very likely the identical robins or song sparrows that charmed us last season, but they come back to us with a new story to tell, and new service to render. They have passed the winter in strange lands, and we may have done so, too; but now, on the home acres, our lives meet and mingle once more.

Does that brief visitation in May of the rarer warblers ever become an old story? We do not see them when they come, nor when they depart; they are here eagerly feeding in the trees in the morning as if they dropped down out of heaven with the rising sun, as doubtless they did; and they are gone in a day or two, as if they had vanished again in the heavens at the going-down of the sun, as is very surely the case. All night they travel through the trackless upper air above the sleeping earth, their pole-star the breeding-impulse. Unfavorable weather conditions will cause them to tarry longer with us some seasons than others. This season (1916) the bay-breasted, the Blackburnian, and the Canada warblers lingered nearly a week with us, and the veery, or Wilson's thrush, lingered and sang in unwonted places. 


\section{THE FAMILIAR BIRDS}

Yesterday I walked in my neighbor's woods and orchards and saw many of these passing warblers the bay-breasted, the black-capped, the magnolia, the black-throated blue, and others. How fresh they looked! They seemed just to have stepped out of Audubon. They conferred a new dignity upon the trees - those old, commonplace scenes, and then this touch of art and science and literature, how novel it was! The male scarlet tanager down in the ploughed field - a vivid bit of color upon the brown earth, how it delighted the eye! A cuckoo called and called in a maple, and then launched out in the air and flew down the hill, its long tail, its slender body, its thin wings, and its characteristic movements how strange when contrasted with the other birds, so different from them all! A robin made a drive at it in the tree, which is a hint that the cuckoo is a criminal among the birds, probably at times destroying their eggs, as has been alleged of it.

Do we ever outgrow the charm and the wonder of the first song sparrow's nest on the ground, tucked away under the grass, or hidden under a mossy bank - a bit of the waste and litter of the great crude out-of-doors taking such neat and pretty shape, and holding such delicate, pearl-like bodies? Can we behold it without a fresh thrill of pleasure? The rough, unkempt field or roadside, and in its midst this delicate, living treasure which a passing foot may crush, or some prowling enemy 


\section{FIELD AND STUDY}

destroy. What trust, what peril, what artless art it all suggests! The April or May day when I find a song sparrow's nest has a touch that the other days do not have; and if a spring goes by without my finding one or more, I miss something from my life. It is not usually by searching that we find a sparrow's nest; it is by accident, or by watchful waiting.

The past season I found my first treasure by watchful waiting. I have found scores of the nests of this familiar dooryard songster, but none that ever gave me more pleasure than this one. The cautious little ground-builder betrayed the secret of her nest to me when, humanly speaking, she thought she was securely keeping it. I knew there was a nest near my study by the song of the male on the trees and bushes around me, and had made some search for it, but without avail. One must first have some sort of a clue to a nest. As I sat here in the summer-house one afternoon with only the most vague thoughts about birds, I chanced to see a song sparrow flit out of the grass near the border of the just-ploughed vineyard, alight upon the freshly turned earth, and in a fussy, nervous way go hunting about for food. Have you ever seen a setting hen come off the nest to feed, and noted how she fluffs out her feathers, flirts her tail, and hurries about as if in ill-humor? My little hen sparrow acted in the same way, and I instantly inferred that she 


\section{THE FAMILIAR BIRDS}

had just left her nest in the grass a few yards below me. She fussed about on the ground for a few minutes, and then flew away, and disappeared in the vineyard. In ten minutes or so she returned to the bit of ploughed ground where I first saw her, and went through the same fussy, nervous manœuvres as at first. Then she came up to a rosebush quite near me and occupied herself there for a few seconds, hopping about amid the branches, and going down to the ground as if in quest of food, mindful all the time, I could see, of my presence. Then she flew back to the ploughed land again, and hopped about, very watchful and suspicious, it seemed to me. She then came a few feet up into the grass and alighted on a small, dry maple-branch that had fallen from the trees above. Here she flirted and attitudinized a moment or two, and then came to the rosebush again and repeated her former movements; then back to the ploughed ground, then to the dry branch, where she sat still and considered a moment, and then hopped down in the grass and disappeared from my view. As she did not again appear, I knew she had gone to her nest. Presently I moved down there very carefully, and, scanning the ground closely, lest I step on the nest, I began the search. When I was within a yard of the nest, which proved to be completely hidden, I heard a rustle in some dry leaves, and saw a rapidly moving line of shaking grass-stems as the bird ran from her nest. Then I 


\section{FIELD AND STUDY}

concentrated my gaze upon the ground and searched it inch by inch, but no nest could I see. Orchard grass grew there in tussocks or stools, and on the lower side of these stools the dry grass of last year sloped down, forming a little thatched roof about their bases; beneath one of these there seemed to be a slight opening; I thrust in my finger and felt the nest, and touched the warm eggs. Never have I seen a more cozy, or cunningly constructed sparrow's nest. No rain could touch it, and no eye penetrate its secret.

Last season my sparrow neighbors built in the heart of currant-bushes and rosebushes, but this spring one of them at least has trusted her secret to the keeping of the grass, and, as it has turned out, has had no occasion to regret it. In due time she brought off her brood, and later in the season succeeded again farther down the hill.

A week or two later, in walking along a secluded, bushy lane leading to the woods, which has been a favorite walk of mine for more than forty years, I chanced upon another secret treasure open to the eye of heaven, which gave me a degree of pleasure greater than any other single incident which my forty years' acquaintance with the old lane had brought me. Encircled by the stalks of a tall-growing weed, I chanced to see upon the ground a deep, bulky, beautifully formed nest. It was a mass of 


\section{THE FAMILIAR BIRDS}

dry leaves and grasses, with an unusually deep and smooth cavity lined with very fine vegetable fibre that looked like gold thread. Evidently a finished nest, I thought, but it was empty, and there were no birds about. It did not have the appearance of a nest that had been "harried," as the Scotch boys say, but of one just that moment finished and waiting for its first egg. A week later I returned to the place and was delighted to find that it was really a live nest. The setting bird had slipped off on my approach so slyly that I had not seen her. The nest contained four small, delicate white eggs marked with fine black specks on their larger ends; these were completely dominated by a large, vulgarlooking cowbird's egg. Presently two anxious birds, one of them strikingly marked with yellow, black, white, and blue-gray, appeared in the branches above my head, and began peering nervously down upon me and uttering a faint "sip," "sip." "Warblers," I said; and, as they flitted excitedly about me, I soon recognized the golden-winged warbler - a rare bird in my locality, and one whose nest I had never before seen. "What a pretty coincidence," I said - "the nest of the goldenwinged warbler at the foot of a clump of goldenrod, and lined with gold thread!" The old, neglected farm lane had never before yielded me such a treasure. Presently a male chestnut-sided warbler, whose song I had been hearing near by - "This, 


\section{FIELD AND STUDY}

this, this, is me, sir" - came and joined the goldenwings, and appeared to share their solicitude, but, after he had inspected me from all sides, moved off in the higher trees and resumed his singing.

"Your nest is not far off," I said, "and maybe in some lucky moment I shall find that also."

What a touch these delicate and striking warblers gave to the old lane! It was like a page from Audubon or Wilson.

The golden-wings, much agitated, kept up their flitting about me till I withdrew. A week later I returned and found the eggs all hatched, probably a day or two before my return; and the big, potbellied cowbird fairly ingulfed the frail little warblers. Up came its head with its wide-open mouth quivering with eagerness. I saw at a glance what would soon be the fate of those delicate baby warblers; they would be overridden and starved or smothered in less than three days. So I took the naked, ungainly interloper in my hand and resumed my walk through the bushy fields, hoping to find the nest of some larger bird with young in it, in which I might place it, and watch the result. I considered myself lucky when I found what I took to be a Savannah sparrow's nest with the young nearly half grown. How closely they pressed themselves down in the nest and made no sign! When I put the little beggar of a cowbird down in their midst, they remained as silent and motionless 


\section{THE FAMILIAR BIRDS}

as ever. It proceeded to creep about over them, every moment or two thrusting up its mouth for food. Will the mother sparrow adopt this bantling, I wonder, and feed it? I had my doubts. The next day I returned and found it still crawling and sprawling about on the backs of its bedfellows, and evidently very hungry. It thrust up its appealing mouth regularly twice each minute during the six minutes I watched it. Evidently it had had no share in the bounty of the nest. Its body had a throbbing movement, like a child with hiccough. I regret now that I did not feed it myself, and continue each day to do so, in order to study further the outcome. I returned the next morning and found the poor thing beneath the heap this time, and quite dead.

As I proceeded to remove its limp and shrunken body, the young sparrows suddenly took alarm and, with their wing-quills only mere stubs, scrambled out of the nest and struggled off in the grass and weeds. I gathered them together and put them back in the nest, but they would not stay. Out they floundered again as soon as my hand was withdrawn. It is always so; when young birds once leave the nest, the movement is final. It is the word of Fate; they will not be put back. They defile the nest as they leave, and that act is a contemptuous farewell.

Haste to leave the nest is characteristic of all 


\section{FIELD AND STUDY}

birds. Their enemies are so many, and the young are so defenseless, that the sooner they get out and scatter and hide, the better it is for them. My sparrows would doubtless have remained several days yet had not my blundering experiment hastened matters. I had set in action the force of a natural instinct before the conditions were quite ripe for it.

Less than one hundred yards from the sparrow's nest I had the good fortune to find the nest of a yellow-breasted chat, one of the shyest and most elusive of our birds. The catbird, the chewink, and the brown thrasher, all skulkers and hiders, do not approach the chat in this respect. It haunts low, bushy fields and tangled, swampy retreats, whence, in May and June, issue the strange, interrupted, polyglot cat-calls of the male. But to see him or his mate, you have got to out-skulk him, and that is no easy task. $\mathrm{He}$ is a fine, strong-looking bird, with his deep olive-green coat and yellow breast and black, curved bill, and black feet and legs. He is one of the hide-and-seek birds. His weird calls have a tantalizing air of secrecy and elusiveness, as if to challenge your curiosity, changing from the quack of a duck to the mew of a cat or the caw of a crow or the bark of a fox or the rattle of the kingfisher.

When you penetrate his retreat he suddenly ceases and begins manœuvring to see you without being seen. In the present case I knew a pair had 


\section{THE FAMILIAR BIRDS}

a nest in the corner of the bushy lot that held the sparrow's nest, because I had heard the male sending forth his polyglot challenge from that vicinity on several occasions, and twice had I ransacked that part of the field and the bushy border of the adjoining field pretty thoroughly. On this day, which was a wet one, I renewed the search, beating through the low growths of sumac and witch-hazel and scrub oak very carefully. As I reached the corner of the field, where my course was barred by an old stone fence, I paused and was about turning back, saying to myself regretfully and half audibly, "I should like to find that nest," when, turning around, I spied the nest in a hazel-bush not five feet from me. The setting bird slipped off as my eye caught her nest, and silently disappeared in the bushes. In a moment more, and while I was inspecting the nest, she appeared fifteen feet away and uttered a sharp, harsh, feline mew. But her mate did not show himself, nor did he during any of my subsequent visits. I often heard him sending forth his unbirdlike calls from the bushes, but never once did I lay eyes upon him, though I tried hard to do so.

The nest was quite a massive structure in the forks of a hazel-bush, about four feet from the ground; it held four handsome, speckled eggs. I should like to have put my young cowbird in such a nest, could I have found it at the right moment, and watched the result. 


\section{FIELD AND STUDY}

This nest prospered; the young were out in due time, but not once did I see or hear young or old after the nest was empty.

The shyness of the chat is instinctive. There is no more reason, in the conditions of its life, why it should be so secretive than there is in those of scores of other birds. Its enemies are those common to its neighbors; but its reluctance to reveal itself to the human eye is phenomenal, though I dare say that men have never yet done it or its forbears any harm. There is reason for the shyness of game-birds, and for the care with which most birds try to conceal their nests, but I can see none for this curious obsession of the chat's. A friend of mine, a psychiatrist, to whom I mentioned this suspicious conduct of the chat's, suggested that he is the paranoiac among the birds, with systematized delusions of harm and persecution, his warped egotism making him believe that every man's hand is raised against him, when there is no ground for such a fear.

The chat has the wisdom common to many other birds of not building its nest in the densest and most secluded part of its haunts, but of selecting a place along their more open edges, where it can the better command the approaches. It seems to be a hardy, prolific bird, yet its numbers are very limited. One pair in a neighborhood is probably above the average. To most country people the bird is an entire stranger. 


\section{THE FAMILIAR BIRDS}

In the woods beyond the chat's nest one of my boy friends conducted me to a nest on the ground beside the path, which he had recently found. He did not know the bird's name, but from his description, and especially from his statement that the bird walked, I was sure he had found the nest of an oven-bird, or the wood accentor. And when I saw it tucked under the dry grass and leaves so that they made a canopy over it, the half-fledged young barely visible in the dim recess, I was as pleased as if I were seeing the oven-bird's nest for the first time. In a moment the mother bird appeared, not blustering about with distressed cries, but silently dragging herself over the ground with spread wings and tail and an utterly decrepit and despairing look. I have rarely seen a mother bird present so pitiful a sight. It was a silent pantomime that was more eloquent than cries. Round and round she went, appearing and disappearing, only a few feet from us, now on this side, now on that, and beseeching and abjuring us to content ourselves with coming and picking her up and leaving her precious young alone. Never did a mother offer to sacrifice herself for her offspring more freely than did this little brown-backed, speckle-breasted bird. Her silent agony soon had its effect on us and we withdrew. A few days more and her young will find their wings. 


\section{FIELD AND STUDY}

Bird-life is the fullest and most intense during the mating and nesting season. Love or war, courting or "scrapping," rule their activities. What jealousies and rivalries, what warring and winning, go on all about us! The birds are all glad and mad at the same moment.

One morning in April I heard the excited voices of bluebirds and robins in the vineyard below me; going down there, I saw a pair of bluebirds and a pair of robins flitting about and perching on the wires and posts in an angry and excited frame of mind. Some of their movements and gestures suggested that they were "scrapping." "But why should bluebirds and robins 'scrap'?" I asked myself. I had never seen them do such a thing, so I began looking about for a common enemy, and expected to find a cat skulking in a ditch there, or maybe a snake. But I could find neither; still the excited and accusing voices kept it up. Then I chanced to see some dry grass and weed-stalks hanging down from a grape-post which was splintered and broken at the top. I found that the robins were building a nest there in a ragged depression on the top of the post, and that a foot and a half lower down the bluebirds had preëmpted a downy woodpecker's old hole, and were making a nest there. The fracas was explained; neither pair of birds wanted the other such near neighbors. Each looked upon the post as its own. I saw that the robins had made a bad choice; no cover 


\section{THE FAMILIAR BIRDS}

or screen of any kind. The first fish crow that flew over in egging time would see the nest and rifle it promptly. I would I could have told the mother robin of the dangerous site of her nest. A week or ten days later I saw her brooding her eggs in apparent security, but not long afterward I found her gone and her nest empty and torn; but as I put my hand in the post, out went the mother bluebird. The crows and jays could not reach her, and she was right in claiming the post as alone suited to her needs. Birds have their troubles as well as we featherless bipeds.

In May the jays are out on their egging expeditions in the groves and orchards. I see two or three together sneaking about - not graceful flyers, or very pleasing birds in summer, but in winter it is a pleasure to see them. Most other birds seem to know them as thieves and robbers. Yesterday one alighted on a post in the vineyard below me and sat quietly taking his bearings. Suddenly a robin came from ambush somewhere and made a vicious pass at him. The jay squatted to avoid the blow, and uttered his ugly "Scat!" The robin took his stand near by and watched him. The jay flew to a near-by apple-tree, and the robin shot in after him very savagely. The jay soon flew down toward the river. I think that the robin does not quite hit the jay on such occasions, but her angry tone and threatening manner make the thief know that she is aware 


\section{'FIELD AND STUDY}

of his purpose. Cry "Thief!" loud enough, and the thief is very apt to take to his heels.

Most of the birds are in a more or less explosive mood in the nesting-season. They alternate between love and anger many times a day. Each bird in nesting-time has its little domain, and is jealous of all trespassers. A male wood thrush quite early in May seemed to lay claim to an old apple-tree near the house where a brood of thrushes were reared last year. He made his headquarters in that tree, waiting, I fancied, for his mate to arrive, and behaving in a decidedly unfriendly way to every robin that invaded his precinct. For days I saw him "scrapping" with robins in and around that tree. The robins, innocent intruders, were taken by surprise.

"What is that speckle-breasted dandy so redhot about?" their manners seemed to say. The thrush would charge the robins spitefully, and follow them into the garden with his threatening gestures and sharp "Quit, quit, quit!" He would always give way when the robin turned upon him, feeling apparently that in a trial of rude strength a poet like himself was no match for a plebeian muddauber like the robin. But he would return to the charge, and keep up his pretty, graceful protests whenever his tree was invaded. Finally his mate, or another female, came, and the two now have a nest there, and all seems well with them. But the male 


\section{THE FAMILIAR BIRDS}

has a rent in his brown coat, and a feather is missing from his waistcoat, revealing the dark-gray lining, and giving him just a suspicion of shabbiness. I am wondering if some indignant robin could not tell how he came by these blemishes.

This particular male thrush, by the way, has the most robin-like note I have ever heard come from a wood thrush. Often his "Fip, fip, fip," is so like the robin's that I have to look to see which bird it is.

When the female had been here a few days I frequently saw the pair inspecting a fork near the end of a low branch of the apple-tree; they were evidently considering it as a likely place for a nest. Then one morning I saw the female bring a piece of white paper and place it in the fork and sit down upon it. She went through this performance several times without making any progress. Once I saw a sheet of note-paper dancing around on the gravel path in a most extraordinary manner, and presently caught a glimpse of the thrush beneath it, holding one edge of it in her beak, and trying hard to get such control of it as to enable her to carry it to her nest. But the problem was too much for her. After I had torn the sheet in strips she took them one by one to the branch in the apple-tree, determined that her domicile should have a paper foundation. But she could not make the paper "stay put"; it quickly fell to the ground. She would peer down upon the fallen fragments in a curious, helpless way, but 


\section{FIELD AND STUDY}

made no attempt to recover them from the wet grass. When white paper is not available, the thrush usually starts her nest with dry maple leaves; she rejects newspapers and colored papers of all kinds. It is probably the printer's ink, and not the politics of the newspaper, that causes her to reject its fragments.

The next day my thrushes abandoned the site where the paper acted so contrarily, and began a nest higher up in the tree, saddling it on a large, horizontal branch, but still weaving a piece of white paper in its foundation. Here the pair prospered, and by the middle of June brought forth their brood of three young. In a warmer season they would doubtless have had four.

On the same wet morning, while on my way to the post-office, in the rain, I saw a wood thrush flying through the dripping trees and bushes with a large piece of white paper in her beak. "Another home being started on a paper foundation,” I said, "and on a wet morning, at that." I followed the bird with my eye and saw her fly to the top of a tall white elder-bush and place the paper in the forking branches. I tarried while she flew over toward the grocery-store for more material. Presently she came back with a long, ragged piece of paper that trailed behind her like a banner. As she flew through the tops of the bushes with her burden, it caught on a limb and fell to the ground. She dived 


\section{THE FAMILIAR BIRDS}

down to recover it, but failed in her attempt. The following day I saw quite a mass of white paper in the tall elder-bush, but the nest made no further progress, and the pair chose another site. I say the pair, but in reality I think the female alone selects the site. Her actions on such occasions seem much the more purposeful and decided. The male attends her, but never, to my knowledge, lends a hand in nest-building. When the young are out, he does his share in feeding them.

I am at a loss to know why certain birds have such a penchant for something white woven into, or placed on the outside of, their nests. A robin will reject bits of colored paper, but will often use strips of white paper or white rags. One in the vines of a near-by shed has made very free use of the cast-off hair of our old gray horse, nearly white. A robin's nest here in the summer-house has a long strip of white silk paper. On a friend's house in a Michigan city I saw more than a yard of candle-wick dangling from an unfinished nest. Even the sly catbird likes a bit of white paper in her nest. Nearly all the vireos have a habit of sticking bits of white material on the outside of their nests, usually the weavings of cocoons of spiders.

One day, high in the branches of an elm that shaded a village street, I saw a yellow-throated vireo at work on her nest. She was evidently in want of the white, felty bits of spiders' co- 


\section{FIELD AND STUDY}

coons to bedeck the outside, and was duped by a white rosebush that was dropping its petals in a near-by dooryard. I saw white rose-petals on the ground under the nest, and wondered where they came from. Keeping my eye on the bird, I saw her fly down to the rosebush, seize a petal and fly up to her nest, and try to make it stick to the outside. But it was not fuzzy or woolly like the spider's material, and would not stick; it quickly came sailing down to the ground. Time after time I saw the bird carry up rose-petals to her nest, only to see them fall back to the ground. She seemed to have no judgment in the matter; the size and the color of the petals were all right, but their texture was not of the right kind. I think she finally gave up the attempt to make use of them.

Do these patches on the side of the dark-gray nest of the vireo help to conceal it - a kind of instinctive camouflage? They help give it a mottled appearance, and in the flickering light and shade of the tree-tops they may help to render it less noticeable, though only to eyes underneath it. A crow or a jay, the bird's arch enemies, would not be misled by them.

It is always interesting to me to see the young birds leave their nest. It is, as I have just said, generally an irrevocable step; they very rarely go backyoung swallows, however, perhaps more frequently 


\section{THE FAMILIAR BIRDS}

than other birds do go back. The nest is in no sense a home, but a nursery for a brief period. Most of our birds who bring off a second brood build a second nest, though a robin will occasionally re-line and otherwise patch up an old nest. Nesting birds leave the nest one by one, sometimes at intervals of an hour or two; at others, of a day or more. A brood of three young bluebirds recently left the nest in a box on the corner of my porch between seven and ten o'clock. The day before, they began to appear in the opening, and to look out upon the bright summer landscape and chirp; now and then a wing was thrust out and exercised for a moment - probably no bird leaves its nest till it has flapped its wings a little. On the morning of the exodus, the young were more than usually restless and loud and persistent in their calls to their parents. The parents in turn called to them in a new way; it was the plaintive, far-away call that the birds utter on their arrival in spring, and that they send forth when apparently starting on a long flight. The young answered back in the same tone - " pure, pure," as if on the eve of a great adventure. Presently the bird that sat in the opening fluttered out and clung to the outside of the box, where it remained clinging and calling for a minute or more. Then, with a sudden impulse, it let go its hold and flew straight to the branches of an apple-tree fifty or sixty feet away. It was a successful flight, and a successful alighting. 


\section{FIELD AND STUDY}

One of the parent birds was on hand instantly, uttering an approving or an encouraging note, or maybe only a note of solicitude. In the course of two or three hours the two other birds left the nest in a similar manner, except that there was no preliminary clinging to the outside - they flew straight from the opening to the old apple-tree, and the next day were drifting about the orchard with their parents. By fall or before, they will probably join the earlier brood, which I think still lingers in this vicinity, and the united families in a loose flock will drift about this part of the country.

In June I saw a brood of young wood thrushes leave the nest. In all cases there seems to be one bird a little more forward than the others. In this case one of the young thrushes perched on the edge of the nest for a few minutes and chirruped. Then, in a blundering way, apparently more by accident than design, it reached the big branch upon which the nest was saddled. After a while it flew a few feet to another branch. The two others, after similar manœuvring, joined it in the course of the day, but neither of them left the apple-tree on that day. At night there was a heavy thunder-shower with violent wind, and in the morning two of the young thrushes were back in the nest. So, under exceptional circumstances, young birds do return to the nest. If they had left the tree, it is quite certain they would not have taken refuge in the nest. But the 


\section{THE FAMILIAR BIRDS}

fury of the elements made them turn to the old cradle; and very human-like they were in so doing. During the day they left its protecting arms, never to return.

One season a brood of house wrens on the corner of the veranda all left the nest, amid much cackling and chattering from both old and young, in a short time early one June morning. One by one they scrambled outside the box, then off into the honeysuckle-vines, where they lingered an hour or more before they tried their wings in short flights to near-by bushes.

I have seen young barn swallows cling to the outside of their nest and beat their wings vigorously a day or two before taking flight. The young of the grouse and quail and of the small water and shore birds run away from the nest the day they are hatched; they trust to their legs long before their wing-quills have sprouted. The young hummingbirds that $I$ have seen leave the nest shot up into the air as if a spring beneath them had been released.

The current notion that the parent birds teach the young to fly - that of set purpose they give them lessons in flying - is entirely erroneous. The young fly automatically when the time comes, as truly so as the witch-hazel nut explodes, and the pod of the jewel-weed goes off when the seeds are ripe. The parent birds call to their young, and I have 


\section{FIELD AND STUDY}

thought that in some cases they withhold the food longer than usual, to stimulate the young to make the great adventure; but in the case of the bluebirds referred to, the young were fed up to the moment of flight. 


\section{IV}

\section{FUSS AND FEATHERS}

DROBABLY we have no other familiar bird keyed up to the same degree of intensity as the house wren. He seems to be the one bird whose cup of life is always overflowing. The wren is habitually in an ecstasy either of delight or of rage. $\mathrm{He}$ probably gets on the nerves of more persons than any other of our birds. He is so shrilly and overflowingly joyous, or else so sharply and harshly angry and pugnacious - a lyrical burst one minute, and a volley of chiding, staccato notes the next. More restless than the wind, he is a tiny dynamo of bird energy. From his appearance in May till his last brood is out in midsummer, he repeats his shrill, hurried little strain about ten times a minute for about ten hours a day, and cackles and chatters between-times. He expends enough energy in giving expression to his happiness, or vent to his anger, in the course of each day to carry him halfway to the Gulf. He sputters, he chatters, he carols; he excites the wrath of bluebirds, phœbes, orioles, robins; he darts into holes; he bobs up in unexpected places; he nests in old hats, in dinner-pails, in pumps, in old shoes. Give him a twig and a feather and a hole in almost anything, and his cup is full. How ab- 


\section{FIELD AND STUDY}

surdly happy he is over a few dry twigs there in that box, and his little freckled mate sitting upon her eggs! His throat swells and throbs as if he had all the winds of Eolus imprisoned in it, and the little tempest of joy in there rages all the time. His song goes off as suddenly as if some one had touched a spring or switched on a current. If feathers can have a feathered edge, the wren has it.

"What bird is that?" asked an invalid wife, seated on the porch near a wren-box. "Is it never still, and never silent? It gets on my nerves."

"Neither still nor silent long at a time," replied her husband, "except when asleep."

It repeats its song at least six thousand times a day for two or three months, at the same time that it brings many scores of insects to feed its young. But this activity does not use up all the energy of the wren. He gets rid of some of the surplus in building cock, or sham, nests in every unoccupied bird-box near him. He fills the cavities up with twigs, and I have even seen him carry food into these sham nests, playing that he had young there. (I saw him do it yesterday, July 7 th; he held in his beak what seemed to be a small green worm.) Not even these activities use up all his energy; it overflows in his shaking and vibrating wings while in song.

The song of the house wren is rather harsh and shrill, far inferior as a musical performance to that of the winter wren. The songs of the two differ as 


\section{FUSS AND FEATHERS}

their nests differ, or as soft green moss and feathers differ from dry twigs and a little dry grass. A truly sylvan strain is that of the winter wren, suggesting deep wildwood solitudes, while that of the house wren is more in keeping with the noise and clatter of the farm and dooryard. He begins singing by or before four o'clock in the morning, and for the first hour hardly stops to take breath, and all the forenoon the pauses between his volleys of notes are of but a few seconds.

I find that there are good bird-observers who accuse the wren of destroying the eggs of other birds. I have no first-hand evidence that such is a fact, but the hostility of several other species of birds toward the wren gives color to the charge. Why, for instance, should the phœbe-bird make a savage drive at him, if she has not some old score of that kind to wipe out? or the song sparrow chase him into a vine or a bush and keep him a prisoner there for a few moments, as I have seen him do?

As I was sitting on the platform of the fruit-house one morning, watching the wood thrushes at nestbuilding, there was a rustle of wings almost at my elbow, and the snapping of a phobe's beak. I turned in time to see a brown speck darting under the floor, and a phobe-bird close on to its heels. The speck was a wren, and the phœbe was driving for it viciously. How spitefully her beak did snap! As the wren eluded her, phœbe turned quickly and 


\section{FIELD AND STUDY}

disappeared down the hill, where she had a nest on a rafter in the lower fruit-house.

This season there are four wrens' nests about my place, in hollow limbs and boxes which we have put up, and three bluebirds' nests. The wrens and the bluebirds often come into collision; mainly, I think, because they are rivals for the same nesting-sites. The bluebird, with all his soft, plaintive notes, has a marked vein of pugnacity in him, and is at times a lively "scrapper"; and the wren is no "peace-atany-price bird, and will stand up for his rights very bravely against his big blue-coated rival.

Late one afternoon, when I was busy in the garden near the end of the vineyard, where there was a bird-box, I suddenly heard the loud, emphatic note of a bluebird mingled with the chiding cackle and chatter of a house wren. I saw the bluebird dive savagely at the wren and drive him into a currantbush, where he would scold and "sass back," and then break out into a shrill, brief song. Presently a female oriole came and joined the bluebird in persecuting the wren, which answered back from its safe retreat in the bushes with harsh chatter and snatches of tantalizing song. The bluebird took up his stand on the grape-post that supported the birdbox in which the wren had a nest, and from this outlook he grew eloquent in his denunciation of wrens. His loud, rapid voice and the answering cackle of the wren attracted the attention of their 


\section{FUSS AND FEATHERS}

bird neighbors. Four robins came, one after another, and perched on the tops of surrounding posts, silent but interested spectators. A male oriole came, a catbird came, two song sparrows came, and then a male goldfinch perched near by. The birds were evidently curious to know what all this loud altercation was about - very human in this respect.

After the bluebird had eased his mind a little about wrens, he dropped down to the box, and, clinging to the entrance of the nest, looked in. Instantly the wren was on his back, scolding excitedly. The bluebird turned to seize him, but was not quick enough, and there was a brown streak, with a blue streak close behind it, to the nearest currant-bush, in which the wren again chattered and sang in derision. The bluebird again resumed his perch above the nest and was louder and more emphatic than ever in his protests. It was really very amusing to see the bluebird stand up so straight there on the post, like a stump orator, delivering his philippic against the wren. His whole bearing and tone expressed indignation and an outraged sense of justice. I fancied him saying: "My friends and neighbors, I want to bear witness before you of the despicable character of this chattering, skulking, impudent house wren. $\mathrm{He}$ is an intolerable nuisance. He crosses my path daily. Every honest bird hates him. He fills up the boxes he cannot occupy with his rubbish, and assaults me if I look 


\section{FIELD AND STUDY}

into them and criticize his conduct. $\mathrm{He}$ is sly and meddlesome, and a disturber of the peace. He has the manners of a blackguard and the habits of a thief and a despoiler. His throat and tongue are brass, and his song is as harsh as the dry twigs he makes his nest of. I ask you to join me in putting him down." His audience listened and looked on with interest, I will not say with amusement. The humor of the situation probably appealed to me alone. The birds were only anxious to find out if a possible common danger threatened them all. But to me the situation had an element of comedy in it, and made me laugh in spite of myself.

Again the bluebird essayed to look into that hole, and as quick as a flash the wren was on his back. Whether or not he used his sharp beak, I could not tell, as the assailed turned upon his assailant so quickly - but not quick enough to get in a counter-stroke. The vines and bushes were again a house of safety for the wren. Three or four times the bluebird asserted his natural right to look into any hole or cavity he had a mind to, and each time the wren denied that right in the way I have described. But such jangles among the birds are usually brief. One by one the spectators flew away; and finally the chief actor in the little drama flew away, and the wren warbled in a strain of triumph.

The next day I discovered that the wren had only begun building a nest in the box, probably a cock 


\section{FUSS AND FEATHERS}

nest. One thing arrested my attention; the box had a big crack in it from the entrance nearly to the bottom. This crack the wren had evidently essayed to stop with twigs. At first sight my impression was that the twigs had accidentally got caught in the crack in the bird's effort to get them into the nest. But, after carefully considering the matter, I see I must credit him with a purpose to mend his house. He had first put two small twigs into the crack and then finished the job with a much larger twig, eight inches long, which closed the opening very effectually. This last twig was larger and longer than wrens ever use in their nests. It was a very clever stroke.

I think the male wrens have sham battles as well as sham nests; they must work off their superfluous animation in some way. For hours one early July afternoon two males, one of whom had a cock nest a few yards below me in a box on a grape-post, and the other a few yards above me in a box on the corner of the veranda, amused and delayed me in my eager reading of the war news (the British had just begun their great offensive in France) by engaging in what appeared to be a most determined song contest from their respective perches a few yards apart. How their throats were convulsed! Under what pressure of jealousy or rivalry they did hurl shrill defiance at each other in that, to me, languid summer afternoon! Back and forth, back and forth, went the voluble challenges, the birds 


\section{FIELD AND STUDY}

facing each other with drooping wings and throbbing breasts. The grape-post wren seemed to be in the more aggressive mood. When he could stand it no longer, he would dart up the hill at his opponent on the low branch of a maple, who never stood to his guns, and the two would make a brown streak in a wide circle around the maples and the Study, and down the hill round the summer-house, keeping just so far apart, and never actually coming to blows. Then they would take up their old positions and renew the vocal contest with the same spirit as before, till one of them was again carried off his feet and hurled himself at his rival on the maple-branch. Round and round they would go, squeaking and chattering, but never ruffling a feather. Hour after hour, with brief intervals, and at times day after day, these two little hot but happy spirits played the comedy of this mimic war. It was not even a tempest in a teapot; it was tempest in a nutshell, but there was a vast deal of nature in it for all that. Both birds simply overflowed with the emotions proper to the season and the conditions.

The mate of the grape-post bird had a nest in a box farther down the hill, where the care of her young occupied her most of her time. She scolded as only wrens can scold when I went poking about her box, but my poking about the box of the male did not agitate the owner at all. I tried to explore the inside with my finger, but found it apparently 


\section{FUSS AND FEATHERS}

packed full of twigs. I had often seen the bird enter it and disappear for some moments, but my finger found no vacant space. Then one day I saw the female enter it, much to the joy and loud acclaim of her mate. I finally saw her carry in fine spears of dry grass. To clear up the mystery I took off the top of the box, and found that there was barely room enough between its top and the twigs for a body the size of my finger to squeeze in, and enter a small, deep pocket in one corner which the cock had cunningly arranged. He had made sure that no bird larger than a wren - no usurping bluebird nor meddling English sparrow could gain entrance, and as for inquisitive wrens, he could meet them at an advantage. Then I examined the lower box, where the young were, which had an opening large enough for a high-hole, or a great crested flycatcher, and found that the foresighted little creatures had used the same tactics here; they had built a barricade of twigs in front of the nest, which was in one corner, and which could be entered by the wrens only by a close squeeze. Artful little people, I said, living joyous and intensive lives, and as full of character and spirit as an egg is full of meat.

This little bird loves to be near your house, but give it a chance and it will come inside of it and nest in the room you occupy. I knew of a pair that came through a screen door left ajar, into a room on the 


\section{FIELD AND STUDY}

second floor of a famous inn in the valley of the Rondout, and built a nest on the sash behind a heavy green window-curtain - a real nest on one side of the door where the brood was raised, and a cock, or dummy, nest on the other side. It was not an inviting place for a nest, except that the room was occupied by a well-known woman artist and writer who seems to have extended a hearty welcome to the little feathered intruders. She cultivated them, and they seem to have cultivated her, sitting on the corner of her table when she was at work, and chattering and singing to her in the most pointed manner. The people in the house who knew of the situation were not slow in coming to the conclusion that the birds recognized in the artist a kindred spirit, and were drawn to her as they are not to other people. The case is at least a suggestive one.

I can relate but one somewhat analogous experience from my own life - remotely analogous, I may say, as I was not alone concerned in the case and the bird involved was not a wren. Some years ago, while on a visit to friends in one of the large cities of the western part of New York State, some members of a bird club and one or two officials of the city government drove me about through the various parks. We came to a park where there was a small aviary, a space thirty or forty feet square, enclosed by wire netting. In this cage were a number of our common birds, but the one that made a 


\section{FUSS AND FEATHERS}

lasting impression upon me, and upon all who accompanied me, was a fox sparrow. No sooner had we paused before the big cage than a strange excitement seemed to seize this bird, and it began flying from one end of the enclosure to the other, clinging for a moment to the wires at each end, and singing in the most ecstatic manner, and by its enthusiasm kindling one or two other birds into song. I had heard the fox sparrow many times, but never before one that approached this one in power and brilliancy. It sang in a strain varied and copious beyond compare - a kind of musical frenzy. It was fairly startling. The man in charge said he had never heard it sing before, nor had any of my companions. I saw at once that the thought in all minds, which soon came out in words, was that the bird was singing to me; that it had recognized me as a bird-lover, and was intoxicated by the discovery. There were other bird-lovers in the company. There is, of course, some other explanation of the extraordinary performance; but what it is no one could suggest. There was nothing striking or unusual in the appearance of any of us, yet our presence seemed to act like fire to a fuse, and that one bird was the rocket that astonished and delighted us all. It darted about the enclosure as if its joy were uncontrollable, and sang in a spirit to match. I venture to say that none of those present will ever forget the incident. The more I thought 


\section{FIELD AND S'TUDY}

about it afterward, the more it impressed me. I am not the least bit credulous about such things; I have never observed that the birds, or other wild creatures, behave in any way exceptionally toward me, or toward any one else. The legends in the old literature of the power of certain saintly persons, like St. Francis of Assisi, over the birds and animals, I look upon as legends merely. They are probably greatly exaggerated accounts of the power of gentleness and kindliness over the lower orders. The movements, the tones of the voice, the expression of the face, all play a part in the impression we make upon man or beast. I have always been successful in handling bees, because I am not afraid of bees, and go among them as if I had a right there. I am successful in making friends with dogs, because I show no suspicion or hesitancy toward them, and, as it were, extend to them the hand of fellowship. But the case of the fox sparrow is the single incident I can recall that might be interpreted, in the spirit of the old legends, as showing special sympathy and understanding between man and birds. The incident of the woman artist with the wrens nesting in her room, and their perching on her table and talking wren-talk to her, is of the same character. Such things may afford hints of some psychic condition, some community of mind between the human and the animal, as yet but little understood, but they are far from convincing. 


\section{V \\ THE SONGS OF BIRDS}

NE of the most remarkable things in animal life to me is the singing of the birds. Perhaps the fiddling of the insects is equally remarkable, but it falls into the same category of remarkable biological facts, and doubtless its genesis is the same.

How shall we interpret the singing of birds? Does it bear any analogy to human singing? Is it directed to any particular end? Is it expressive of joy, as it would seem to be? Is it to please and win the female? It is most assuredly what the biologists call a secondary sexual characteristic, as it belongs to the breeding-season, and is associated with the bright plumage of the males that comes at this time. But I am persuaded that the females give little or no heed to it. Only so far as it helps make up the sum of other plus qualities which are characteristic of the males, such as ornate appendages, bright colors, and general pugnacity, does it count with the females. The female among the birds is not so much won, in the human sense, as she is conquered or dominated. She resents courtship, and often meets would-be caresses with blows. What finally determines her choice of any particular male would be hard to decide, though it seems to be the vigor of his 


\section{FIELD AND STUDY}

address, which, of course, would again be expressive of his all-round conquering character. The positive body will always dominate the negative, and that, in short, is why the male dominates the female. What country boy has not seen a female sparrow, or robin, or bluebird, apparently a disinterested spectator of the battles of her male suitors? If she secretly wishes for the success of either of the combatants, she has the art of completely concealing it. The victor takes the prize.

That the singing of birds bears no analogy to the singing of human beings, and is neither to please themselves nor to please others, is obvious from at least two facts: one is that birds with defective or only half-articulate voices will sing just as joyously and persistently as do birds whose instruments are perfect. I have witnessed this in the case of the hermit thrush, the bobolink, and the cockerel of the barnyard. The birds of the wood, and of the meadow, quite ignored their split whistles, and the cockerel arched his neck and inflated his lungs and went through with the motions of crowing just as proudly and repeatedly as did the cock he was challenging. Then the seasonal and automatic character of bird-songs, and their tireless persistence, mark them off from all human performances. If a man or a woman were to use his or her voice one thousandth part as much as the singing bird uses its voice, he or she would soon be so hoarse that speaking would be 


\section{THE SONGS OF BIRDS}

impossible. Man's vocal organs, at least those of the mouth, are made of quite different material - the palate and soft and flexible lips and tongue while the bird has hard and horny tongue and bill. The singing-organs of the live bird do not differ very much from those of the artificial bird which you wind up, and which sings and throbs much like the real thing. The music-box of the bird is called the syrinx, and is composed of hard cartilaginous rings which do not seem to be much more susceptible of fatigue and wear than a tin whistle. The bird's song repeated a thousand or more times a day for months does not seem to affect it in the least. All singing birds, and all birds with loud calls, have this anatomical contrivance in the trachea called the syrinx.

Our turkey buzzard has no voice because it has no syrinx. Maybe Nature did not dare trust the uncleanly glutton to speak. The hawks and the eagles she seems more liberal with because theirs is a nobler type of savagery. And yet, not to be too sure about Nature's motives, there is the European stork, a rather noble bird, which has no voice. It is not easy to fathom Nature's inconsistencies. See what a voice she has given to the frogs, while she has given none to the turtles! Behold the noisy crickets and grasshoppers and the silent moths and butterflies, the whistling marmot and the silent skunks and porcupines!

As I sat on my porch this chilly July morning 


\section{FIELD AND STUDY}

about eight o'clock, while a slow rain was falling, a song sparrow was singing from the top of a dead plum-tree across the road in front of me. He was repeating his song at the rate of five times a minute, and had been doing so with but very short breaks since about four o'clock. It is the middle of July, and this bird has been in song since some time in April. The season is a very late one (1917), and I think his mate is yet incubating. As is usual with the song sparrow, he has five different songs, and he shifts from one to the other at irregular intervals. The change is as marked as that of the organgrinder when he goes through his repertoire in front of your window. He repeats each one from eight to ten times. We call him "Mrs. Durkee," because in the last phrase of one of his songs he says, "Mrs. Durkee," very distinctly.

The main business of his life seems to be singing. Four fifths of his time from sunrise to sunset he is perched on the top of the old plum-tree going through his musical repertoire. Getting his living appears to occupy very little of his time, and if he visits his mate or in any way contributes to her well-being, he does it on the sly. Each song consists of not more than six or seven notes, and its delivery takes two or three seconds. At intervals he shakes off the raindrops. In the distance I faintly hear another song sparrow going through a similar performance, but with songs of his own. Indeed, I am convinced that 


\section{THE SONGS OF BIRDS}

each sparrow has his own set of songs. In the beech and maple woods on a knoll above me I hear, day after day, rain or shine, a scarlet tanager repeating his song at almost all hours of the day, but without the variations that the sparrow has. Sometimes he comes down from his sylvan retreat and sings for a few moments from the dry branch of an apple-tree near us, delighting the eye with his scarlet coat more than he does the ear with the burr in his voice. His visits are brief. He is soon back to his maple retreat, where his song is mellowed by distance. But from the little sparrow on the old plum-tree there is no escape. His persistent singing, early and late, in this great country solitude becomes the dominant fact. You cannot ignore it. It is as insistent as the clock. He rings the changes of his five songs into your ears over and over, ten times, a hundred times over, in the morning before you are up. He reiterates them tirelessly all the forenoon. They stand out sharply upon the great silence. They challenge your attention almost to the verge of irritation. There is a slight let-up in the afternoon, but "Mrs. Durkee" is the last sound we hear as the twilight settles down. There are no insect voices or other sounds, and the little singer has the listening world all to himself.

The question recurs to me, Does the feeling or impulse which prompts the birds to sing correspond at all to the feeling that prompts human beings to sing? Does it give them or their mates pleasure? Is 
it expressive of joy or happiness? Or is it a natural automatic expression of the male sexual principle the overflow or surplusage of the breeding-instinct, such as the brilliant colors and strange antics of male birds generally? After the young are hatched this singing of the male will begin to slacken, until shortly before September it stops entirely. The tide of bird-song is usually at its height in June, and it begins to ebb in early July. The rollicking spirit of the bobolink is at this time clouded by care and anxiety about his young, and his song is only heard fitfully and in snatches. As I pass along a road by a meadow where a pair has young, the agitation of both birds is very marked; they publish to the passer-by in every way possible that they have hidden in that timothy grass young that they are very solicitous about. They hover in the air and utter their alarm notes, and if I pause near, the male becomes so excited that a snatch of his song comes out now and then amid his rapidly uttered chiding notes. His joyous level flight on quivering wing changes to the hurried, abrupt, jerky flight of the female. The female bobolink always seems in bad humor, nervous and hurried and out of sorts with the male that so dotes upon her. All his ecstatic singing seems to make no impression upon her; the singer alone seems to joy in it, and to be proud of his performance. ("The song is to the singer and comes back most to him," says Whitman.) Indeed, 


\section{THE SONGS OF BIRDS}

this is the case among all classes of birds; the females have unmusical ears and appear to be annoyed rather than charmed by the songs of the males. Behold, even the hens in the yard shake their heads protestingly as if it hurt their ears, as it probably does, when the cockerel arches his neck and utters his strident and self-satisfied challenge to all the world. The females of all species are more averse to noise than the males, and are less self-assertive unless the well-being of their young is at stake, when they can outdo the males. Female nature is timid and retiring, even in the vegetable kingdom, while the male is more showy and aggressive, at least during the breeding-season. The singing of birds belongs to this phase, and, I think, is no more addressed to the female than it is addressed to all the world.

It is the prean and celebration of the fecundity of Nature. These colors, these ornaments, are the spangles upon her garments; they are an extra touch, an artistic flourish, an evidence of the festive spirit that goes with the primal command to "increase and multiply" - the one end which all nature has most at heart. The bird sings, the cock crows, the tom turkey gobbles, the prairie chicken booms, the woodpecker drums, the frog croaks, the crane trumpets, the stag bugles, the bull roars, the insects fiddle - all instruments in the great orchestral celebration of this aboriginal impulse.

On the same old plum-tree where the song spar- 


\section{FIELD AND STUDY}

row sings, perch every hour in the day two bluebirds who are busy feeding their young in a cavity excavated by a woodpecker in a maple-stub on the corner of my porch. They do no singing, but seem to converse in soft warbles, and they signal to each other in gentle wing gestures. They do not heed the singing sparrow, nor he them, but they often dive spitefully at the "chippie" when she comes about her own private business in the grass under their brood.

The bluebird is not a singer like the robin or the sparrow, but he is one of our soft, sweet-voiced birds, with many pretty ways that greatly endear him to all country people. He is clearly an offshoot, back in biologic time, from the line of thrushes, and he inherits their soft voices and pleasing manners, but not their musical talents. Nature has made amends to him in his extra color.

Here we strike the exceptional fact in bird-life, the non-singing birds, such as our bluebird, our cedar waxwing, our nuthatches, our kingbird, and others, all of which have their calls more or less musical, but none of which are deliberate songsters. The cedar-bird has the least voice of any of our small birds that I now recall, his sole note being a fine, beadlike sound which he usually utters on taking flight. Approach his nest or young and, so far as I have observed, he shows no other sign of agitation than depressing his plumage and assuming 


\section{THE SONGS OF BIRDS}

a very stiff, straight attitude, which does, indeed, give him a wild, startled look.

Our woodpeckers do not sing, but instead they beat a drum in the shape of a dry, resonant limb. which seems to be expressive of the same breedinginstinct. The flicker has a long, oft-repeated call which he alternates with his drumming, and that is one of the most welcome of vernal sounds. The drumming of the yellow-bellied woodpecker is the most unusual of them all; the bird delivers five strokes on his drum, three of them rapidly, and then two with longer intervals between. This variation gives it a little touch of art. The drums of the pileated and the ivory-billed woodpeckers I have never heard.

All our song-birds sing with mechanical regularity and persistence. It is as if they were instruments wound up to go off at a certain time, and to continue for a certain time. I know of no species that during the breeding-season does not repeat its song many thousands of times a day or night.

Every morning in my walk I hear a vesper sparrow on the edge of a pasture repeating his song from the top of a thorn-tree at the rate of seven times a minute, without any variations that I can detect. One morning when I was timing him he suddenly stopped without changing his position. On looking up I saw a big hen-hawk just issuing from the roods two or three hundred yards above. After the hawk 


\section{FIELD AND STUDY}

had sailed away and disappeared behind the woods, the bird went on with his singing. The red-eyed vireo in a wood near by was repeating his song much more rapidly; there was barely a perceptible interval between its phrases. This bird sings as he feeds, like the warblers, and he keeps up a continuous strain of cheery notes nearly all summer. He comes pretty near being a perennial songster.

I conclude, then, that the singing of birds bears little or no analogy to human singing. It is confined to one sex and to a particular season, and is simply the overflowing of a universal impulse in living nature.

In the care of their young, birds show something much nearer to human emotion than in their song. Their untimely signs of alarm often betray them, but in the agony of their grief they are very human.

Yesterday, on hearing a great commotion among the birds in the fruit and shade trees in front of my house, I looked up and saw a crow making off with a young, unfledged robin in his beak, pursued by a mob of birds vociferating loudly. A pair of robins, one of whose young the black devil had seized, screamed in agony. It was the ordinary alarm note uttered under such a pressure of excitement that it became a shrill scream like that which a human mother might utter if she saw an eagle or a wolf carrying away her child. There can be little doubt, I thought, that the cases are closely parallel: those 


\section{THE SONGS OF BIRDS}

robins clearly experienced what we must call pain, as would human beings under like circumstances. The great difference is that with the birds the incident is soon forgotten. A natural instinct is outraged, and for the moment the birds react violently. But the divided waters soon close, and the loss is forgotten. In the case of the human mother we know it is different. Birds quickly forget, and the loss of the young or of a mate is usually only the incident of a day. A new mate is quickly found, and a new brood is soon on the road.

The wild creatures are all under the absolute law of Nature, and no time is wasted in pity or regret. The parental affection continues so long as the wellbeing of the young demands it, and little longer. The bluebirds rearing their brood on the corner of my porch reared an earlier brood which they dismissed weeks ago, and which now gives them no more concern. To keep up your end in the great adventure of peopling the world, and waste no time in lamenting over your failures, is the unwritten law of Nature.

Birds with the flocking-instinct sometimes sing in concert. The prettiest instance known to me of this habit among our birds is that of the goldfinches, which in spring have their musical reunions - a sort of sängerfest which often continues for days, and during which the matches appear to be made. But with most of our birds the song is a sort of 


\section{FIELD AND STUDY}

battle-flag of the males, and when they unfurl it, if it is not a challenge, it certainly indicates that they have the "fighting edge." It is a notice to other males that "this grove, or this corner of the field is $m y$ territory, and I will tolerate no trespassers."

The scarlet tanager, to which I have already referred, sings almost continuously. His battle-flag is unfurled nearly all of the time. This morning I heard a rival in the woods below, three or four hundred yards away. The two birds seemed to be engaged in a song contest. Presently the one in the woods came down to a maple-tree in the pasture as if he had said, "I will meet the braggart halfway." The other bird took up the challenge and came over to the edge of the woods near the pasture. The rival singers soon found the strain too great, and when I looked again I saw one pursuing the other in a hurried, looping, swooping flight through the air. It appeared to have been a "peace without victory," and the two birds were soon back, each on his own domain, celebrating his triumph. Such song contests and collisions are very common among the males of all species at this season.

A duet, or a quartet, or a sextet, among the birds is not to be thought of. Each singer wants at least a bit of the listening world all to himself. He is jealous of all other songsters of his kind if they encroach upon his domain. Birds that sing in concert, like the goldfinches and the grackles, are the exception. 


\section{THE SONGS OF BIRDS}

I have not observed that the robins have these song contests, but the robins scrap so much that they surely find enough other provocations to arouse their ire.

That caged and unmated birds sing in the season of song shows that the song impulse is a part of the great breeding-passion that surges through all animal life in the vernal season. It is one with the painted flowers, the drifting perfumes, and the extra ornaments and appendages that so many forms of life put on in fulfilling the primal command to "increase and multiply." 


\section{VI \\ ORCHARD SECRETS}

A FTER I gave up hunting for the bird's nest A I found it. Day after day I had searched through my orchard for a kingbird's nest which I knew from the action of the birds and their constant presence there was in one of the apple or pear trees. I looked them all over in vain, time after time. Then I lay down in the grass under one of the tall trees and kept my eyes on the birds. It was a warm, ripe midsummer afternoon and the fragrance of the world of grass about me and the repose of nature on all sides fairly drowsed my senses. I took a languid interest in watching the two birds and seeing them climb high in the air, now and then, and overtake some bug or beetle that was venturing forth for a pleasure flight in the upper regions of the air, and then pitch down with their prey in their beaks.

I became so interested in these aerial excursions of the two birds and the lumbering, slow-moving insects that they were picking out of the air, that I quite forgot the nest. After a while, casually turning my head to one side to rest my eyes, I saw the nest on a branch not twenty feet away from me. Nests least concealed are often concealed the most. The 


\section{ORCHARD SECRETS}

thicker foliage and the closer branches of the near-by pear-trees offered much more concealment, and upon these I had fixed my scrutiny, and had only run my eye hurriedly over the more open branches of the apple-trees. But there was the nest near the end of a long, low, horizontal branch, with no screen of foliage, and likely to escape the attention on this very account.

The picture of those kingbirds going slowly up almost straight in the air and seizing those insects lingered in my eye. I think at times that they rose nearly one hundred feet, indicating their remarkably sharp vision. In no instance could I see the bug. Probably the eyes of all birds are much sharper than our own. Day after day I see the bluebird fly from her perch on the telephone-wire in front of me to the road or the turf forty or fifty feet away, and pick up some small worm or insect which I myself could not see. Probably the optical instrument of birds is no more perfect or powerful than our own, but the big brain behind it - big relatively - is constantly thinking bug or worm, so to speak. I presume most men could see a gold dollar farther than a bird could. The hawk poised on wing high in the air will see a field mouse in the grass beneath him that under the same conditions would escape our vision. Field mice are in its mind, yes, in its blood. The buzzard, "housing herself in the sky," sees with her craving maw her proper food miles and 


\section{FIELD AND STUDY}

miles away. Our vision, under the circumstances, would not distinguish the carcass of pig or dog from any other small object on the ground. There is speculation in the eye of the buzzard. It is a great help to the eye to know what it is looking for.

But to return. Birds' nests may be found by searching. Yesterday four of us - three young women and myself - went out into the small orchard that holds the kingbird's nest, and by careful scrutiny of each tree we found five other nests a red-eyed vireo's, a cedar-bird's, a goldfinch's, a chippie's, and a song sparrow's. Song sparrows are habitually ground birds, but they occasionally take advantage of a tree. I had never before seen one build a nest fifteen feet from the ground. Evidently the little bird felt that its tree enemies were less to be feared than its ground enemies. I had had a glimpse a day or two before of one of its ground enemies in the grass under the nest, in the shape of a skunk. His approach was betrayed by the trembling of the grass. I called "Halt!" to him, when he stopped and worked his nose in my direction for a moment, then turned and with tail erect ready for action, retraced his steps to the woodchuck-hole under the wall. Both by night and by day these prowlers destroy many birds' nests. The cedar-bird was the rarest find, and I had great pleasure in observing the manners of the parent birds. They made no outcry, but were the personification 


\section{ORCHARD SECRETS}

of silent fear. The male as he sat on a branch near the nest stood up straight and stiff, still as if frozen, with crest flattened and plumage closely furled. The head of the female, visible above the rim of the nest, showed the same alarm. The silent expression of both birds was as eloquent as the most demonstrative outcry. The vireos gave themselves away by their plaintive and agitated cries, the female showing much the more concern. A close scrutiny of the outer end of the lower branches of the trees soon revealed the little gray, closely woven basket suspended between two twigs, seven or eight feet from the ground. A daintier and prettier nest than the vireo's cannot be found. We feel sure that there is the nest of the wood pewee in the old orchard yet to be discovered. This is a nest of a different order - a cup and not a basket, but it is so compactly and smoothly modeled, and so harmonizes with the branch upon which it is placed, by bits of lichen with which it is covered, that it delights the eye equally with that of the vireo, and is still harder to find. The tribe of vireos have doubtless learned from long experience that the safest places to build their nests are where we invariably find them, near the end of long, low branches of trees and bushes. The crows and jays are almost sure to overlook them here, and the cowbird in looking for a nest in which to drop stealthily her egg is equally baflled. The goldfinch is also a superior bird archi- 


\section{FIELD AND STUDY}

tect. Its nest is massive for so small a body - thick, compact, smooth, soft, deep, and securely held in the small forks of an upper branch. Much thistledown is ordinarily used in its construction.

The chipping sparrow is a poor nest-builder compared with either of the foregoing birds. Her nest is loosely woven of small sticks and straws, and is rarely well-secured to the branches. The sudden summer gusts of rain and wind wreck more chippies' nests than those of any other tree-builders.

The kingbird is a harsh-voiced and harsh-mannered bird, and its nest of crabbed rootlets and sticks and straws is in keeping.

A few weeks later in the season I had a curious, but at first rather painful, experience with the goldfinch's nest. The nest was remarkably well hidden, and the parent birds were so cunning that with all my watching from my hammock a few yards away I never once saw either of them near the nest. Finally in August I concluded that the nest was not occupied, and I did what I rarely do with a bird's nest, I proceeded to "collect" it. With a long pole I lifted it from out the forked branch that held it, and after considerable engineering, caused it to fall to the ground. As it did so, to my dismay, a young bird fell from the nest and struck the stubbled ground heavily. The nest landed bottom side up. Turning it over, I was shocked to find three young birds nearly half grown, wedged into the 


\section{ORCHARD SECRETS}

bottom of it and lying so closely and so still that they seemed a part of the nest. They made no sign, their eyes were closed, they flattened themselves down, and clung to the nest with silent tenacity. I was in a "pickle." What could I do toward undoing what I had so rashly done? The mother bird now appeared, and in the near-by branches called out in shy, plaintive tones, "Pi-ty, pi-ty," but did not come into the tree where her nest had been.

After some delay, with the aid of a ladder, I placed the nest in a forked branch four or five feet below the original position. I had serious doubts about the success of the experiment as not once during the two or more hours that I was on the lookout did either of the parent birds enter the tree. But next morning I found all four of the young birds warm and hugging the nest as closely as ever. Not once during the days that followed did I see the parent birds approach the nest or show themselves in near-by trees. Still the young grew and presently their backs and heads began to show above the rim of the nest, till finally I found one of them perched on its rim. It was not many hours after that before the nest was empty, and later the young were following their parents about the fields from thistle to thistle, uttering that childlike note which sounds like "Ba-by, ba-by," a sound I knew so well in late summer when I was a boy on the old farm. 


\section{FIELD AND STUDY}

The discovery of a bird's nest is usually so much a matter of chance that I always consider myself in luck when I find one. One morning in a little opening which the woodchoppers had made in the beech roods, I stumbled upon a junco's nest. It was in a mossy bank near a pile of cordwood. The mother bird flew out from the little cavity in which the nest was placed, when I was about a rard from her. After that, in my walk, I found my steps very often taking that course. In some way I felt mrself responsible for that nest. I ranted to see it through. Then a bit of still wild life in the great unkempt, haphazand out-of-doors, exposed to so many dangers both by night and by day, so frail and so engaging, one of the most pleasing open secrets in all the woods and fields, drew me by a magic all its omn. A large herd of dairy cors browsed and trailed through these moods and I wondered if the little nest could long escape their hoofs. The night promlers, too, - the skunks, foxes, coons, cats, - would they all pass it by? I used to linger about it. I could see the bird's white beak and her black, shining eyes there in the small carity, partly screened by vines and rild. roodsy gromths. The spot seemed a little different from all others. I laid some poles and brush carelessly about to ward off the corrs. One hot morning I sat a long time on a rock near by, partly to enjoy the cool breeze and partly to be near the junco. I occasionally saw the male hanging 


\section{ORCHARD SECRETS}

about. It was interesting to speculate as to whether or not he understood what kept his mate there. This was doubtless their second broor. A month earlier I had discovered a junco's nest under the roots by the wooded roadside, on the summit of one of the Catskill ranges. As I paused to wipe my brow, the mother bird slid out from the bank only a step from me and went trailing her plumage across the road. The nest was placed nearly a foot under the interlacing roots of the trees.

The gentle divinities safeguarded my bird of the beech woods, and her brood was successfully launched.

I am interested in birds' nests which I do not find, but of which I have only a hint. One July day a fully fledged rose-breasted grosbeak, evidently a good deal bewildered by his first trip in the world, came into our veranda and clung to the rafters above our heads. The male grosbeak was following him in an anxious state of mind and alighted in a near-by tree. I took my cane and, gently insinuating it under the young bird, induced him to let go the rafters and cling to it. Then I carried him to the open and gave him a chance again to try his wings. The parent bird followed him till both were lost from sight. I hunted the orchard over in vain for the nest. It was probably in the woods above or along some bushy fence-rom. The rose-breast is such a rare and striking bird that the incident makes 


\section{FIELD AND STUDY}

a bright spot in my memory of that summer afternoon.

A chickadee had a nest somewhere in the old orchard, but we failed to find it. Several mornings in succession she came upon the veranda and filled her beak with the long woolen nap from my steamer rug. She was very bold, as chickadees usually are, and did not mind a bit my standing a few feet away and upbraiding her.

"You are not a good neighbor," I said - "robbing my bed to furnish your own."

She only kept her beadlike eyes upon me and went on with the pilfering. She made a very pretty appearance with her beak filled with the yellow, green, and black wool - a nest-lining, I venture to say, that she had never had before. Each time she disappeared around the corner of the house into the orchard so quickly that my eye failed to follow her. I only hope that her brood throve and that she will come back next summer to help herself to my supply of wool.

The hermit thrush that came two mornings in September and fed upon the berries of the tall spikenard plant that grows in the rear of the house under the pantry window, had probably had a nest in the near-by woods or on the mountain above, as the hermit was in song there earlier in the season, but I never chanced upon it in my walks. It was a pleasure to have this rare songster come to my door 


\section{ORCHARD SECRETS}

for his breakfast. How much he brought with him of the wild grace and harmony of nature!

I also became interested in a pair of bobolinks which had a nest in a meadow by the roadside where I passed daily. A singular thing about it was that there were two males and only one female. When I approached, one of the males and the female showed great agitation. Hovering in the air above me, they gave away the secret of the cause of their agitation in vociferous tones, while the second male remained entirely indifferent. Clearly it was not a case of plurality of husbands, and it looked as if the second male was there only to keep them company.

Bobolinks in our Northern meadows are becoming more and more rare, and this was unmistakably a case where there were more males than females.

Although bobolinks always show unusual agitation as you approach the vicinity of their nest, they are very careful not to give away its precise locality. Their solicitude embraces the whole meadow. They will follow you from one end to the other with the same outcry and protest, but you may linger about for hours and not get any clue to the particular tuft of grass where the secret is hidden. 


\section{VII}

\section{NATURE IN LITTLE}

TATURA in minimis existat." This saying of 1 Aristotle's is usually translated as if it meant that Nature is seen only, or more fully, in "leasts," whereas it is more probable that Aristotle meant to say that Nature is as complete in the small as the great, that she is whole in all her parts - as much in evidence in the minute as in the gigantic, in the herb as in the oak, in the gnat as in the elephant, in the pond as in the sea. In the clay-bank washed by rains you may perceive the same sculpturing and modeling that you see in vast mountain-chains. In California I have seen, in a small mound of clay by the roadside that had been exposed to the weather for a few years, a reproduction in miniature of the range of mountains that towered above it, the Sierra Madre.

A rivulet winding through a plain loops the same loops and ox-bows that the Mississippi makes traversing the prairie States. The physical laws at work are the same in both cases. Has not some poet said that the same law that shapes a teardrop shapes a planet? The little whirlwind that dances before you along the road in summer, and maybe snatches your hat from your head, is a miniature cyclone, 


\section{NATURE IN LITTLE}

and in our hemisphere it rotates in the same direction - in opposition to the hands of a clock.

Mere size does not count for much with Nature; she is all there, in the least as in the greatest. A drop of dew reveals the rainbow tints as well as the myriad drops of the summer shower, and the bow hovers in the spray of a small waterfall as surely as in that of Niagara. The thunderbolt leaps with no more speed across the black chasm of the clouded heavens, than does the electric spark in your laboratory leap across the tiny spaces from one pole to the other.

But the big-lettered and startling headlines in Nature's book occupy the real nature-lover less than does the smaller print. The big and exceptional things all can see, but only the loving observers take note of the minor facts and incidents.

Emerson in his journal thinks it worth while to notice the jokes of Nature. He cites the Punch faces in the English violets, the parrots, the monkeys, the lapwing's limping, and the like petty stratagems of other birds. He might have cited the little green tody of Jamaica, which is a clownish-looking little bird with its green suit and big golden beak, as if it might be playing a part in some bird carnival. The puffins of the Northern seas, with their jewlike profiles and short legs, also suggest the comic side of Nature, as do the big gray pelicans in the Southern seas. On the wing, or riding on the wave, the pelican has a bulky, awkward look. But there are 


\section{FIELD AND STUDY}

moments in its life every hour when a sudden and complete transformation in its appearance takes place; and those are when it dives for a fish. Its heavy flight is suddenly arrested in the air fifty or more feet above the water, and a striking change in its looks and manner takes place; it turns downward, its pouchlike bill becomes a long, straight dagger, its wings are furled, and its whole form becomes like a gigantic arrowhead which shoots downward and smites the water like a thunderbolt. The spray flies, you hear the concussion, and the huge form disappears beneath the wave. But only for a second; in a twinkling it is again riding on the water, looking as awkward and as commonplace as ever. But of course Nature does not joke; it is man that jokes and experiences a sense of humor in certain of her forms, but all these forms have serious purposes. Inanimate things often behave in a way to excite one's risibles, but that end can be no part of the plan of Nature. When inanimate things act like human beings we laugh, and when human beings act like inanimate things we laugh; why we laugh it would not be easy to say.

Most animals certainly have a keen sense of play, but it is very doubtful if even so humanized an animal as the dog has any sense of humor. The grotesque is pretty sure to frighten him instead of amusing him. The sense of humor implies powers of ideation, which the lower animals do not possess. 


\section{NATURE IN LITTLE}

The waltzing and saluting and other courtship antics of certain birds are very amusing to the human spectator, but it is all a very serious business with the birds. I always have to smile when I see a chipmunk come up out of his hole into which he has been hurrying his winter food-supply, stand up straight on his hind legs, and quickly wash his face. How rapidly he passes his paws over that delicate nose and face, looking around the while to see if any danger is near! He does this at every trip. When we say on witnessing any act of an animal, "How cunning!" we feel, I suppose, a sense of its humanness; it suggests our own behavior under like conditions.

Last spring the vanishing of the deep snows from my lawn gave me a glimpse of the life and works of the meadow mice in their winter freedom under the snow. At one place standing out very clearly was a long mouse highway, sunken into the turf and leading to a large dome-shaped nest of dry grass which it entered by a round hole on one side, and came out by a hole on the other, then forking and becoming two highways leading off over the turf. It suggested a tiny railroad station with its converging lines. "How cunning!" exclaimed some schoolchildren and their teacher to whom I pointed it out. The mice had enjoyed the privacy, freedom, and safety there under the two feet of snow, as the record they left clearly showed. 


\section{FIELD AND STUDY}

I smiled one day last April when, walking near the edge of a small pond, I saw a muskrat on shore very busy stuffing his mouth with dry leaves, then taking to the water, holding his bedding well up till he came opposite to his hole in the bank, when he dived and swam to its underwater entrance. My smile was provoked, I suppose, by the discrepancy between the care the animal took to secure dry leaves, and the necessity that compelled it to plunge under the wave in order to reach its chamber. I do not suppose the muskrat could have interpreted my smile had he seen it and tried.

I was interested and amused by the behavior of the big garter snake I met in my field walk one October day. The day was chilly and I could not stir the snake into any considerable degree of activity. He was sluggish and made no effort to escape, though I teased him with my cane for a quarter of an hour. He presently woke up enough to scent danger in my cane. Probably he had a dim sense that it was another snake. He flattened himself out and became a half-round, opened his mouth threateningly, but would not seize or strike my stick. He coiled beautifully and when I turned him on his back he righted himself quickly by a movement the whole length of his body. After a while I noticed that his body began to contract at a point about one third the distance from the end of the tail; then, as I continued my teasing, he folded the rear part 


\section{NATURE IN LITTLE}

of his body back upon himself and twined it around the forward, like a vine doubling upon itself. If he was taking precautions against my stick as another snake trying to swallow him, it was good tactics; it would have made the problem of swallowing him much more difficult. I do not think it at all probable that the snake had ever experienced such uncivil treatment before, and the emergency was met by the best resources the poor half-benumbed creature had. "Swallow me, if you will, but I will stick in your throat if I can." I left him unharmed, doubled and twisted in self-defense.

Jokes in nature, no! but there are curious and amusing forms and incidents, grotesque shapes, preposterous color schemes and appendages, from our point of view, but all a serious part of the complex web of animal life.

The transparent trick of the ground-building birds to decoy you from their nests or young is very amusing, but the heart of the poor mother bird is in her mouth.

The cock, or mock, nests of the house wren and marsh wren look like jokes; in fact the wrens themselves seem like jokes, they are so pert and fussy and attitudinizing, but whether these extra nests are sham nests, or whether they are the result of the overflowing measure of the breeding-instinct, or are decoy nests, serving a real purpose in concealing or protecting the real nest, is a question. 


\section{FIELD AND STUDY}

There are more tragedies in wild life than comedies, and fear is a much more active agent in development than joy or peace. The only two of our more common wild animals that I recall, in which the instinct or impulse of fear is low, are the porcupine and the skunk. Both are pretty effectively armed against their natural enemies and both are very slow, stupid animals.

When I stop to contemplate the ways of the wild creatures around me and the part they play in the all-the-year-round drama, my thoughts are pretty sure to rest for a while on the crow. From the wide distribution of the crow over the earth in some form, it would appear that Nature has him very much at heart. She has equipped him to make his way in widely diversified lands and climates. He thrives upon the shore and he thrives upon the mountains. He is not strictly a bird of prey, neither is he preyed upon. What is it in nature that he expresses? True, he expresses cunning, hardiness, sociability; but he is not alone in these things. Yet the crow is unique; he is a character, and at times one is almost persuaded that he has a vein of humor in him. Probably no country boy who has had a tame crow has any doubt about it. His mischief-making propensities are certainly evident. His soliloquies, his deliberate catcalls and guttural sounds, his petty stealings, his teasing of other animals, his impudent curiosity, all stamp him as a bird full of the original Adam. 


\section{NATURE IN LITTLE}

Country people are now much more friendly to the crow than they were in my boyhood. He is not so black as he was painted. The farmers have learned that he is their friend, for all his occasional corn-pulling and chicken-stealing. His is the one voice you are pretty sure to hear wherever your walk leads you. He is at home and about his own business. It is not his grace as a flyer that pleases us; he is heavy and commonplace on the wing - no airiness, no easy mastery as with the hawks; only when he walks is he graceful. How much at home he looks upon the ground - an ebony clod-hopper, but in his bearing the lord of the soil. He always looks prosperous; he always looks contented; his voice is always reassuring. The farmer may be disgruntled and discouraged, his crows are not. The country is good enough for them; they can meet their engagements; they do not borrow trouble; they have not lived on the credit of the future; their acres are not mortgaged. The crow is a type of the cheerful, successful countryman. He is not a bird of leisure; he is always busy, going somewhere, or policing the woods, or saluting his friends, or calling together the clans, or mobbing a hawk, or spying out new feeding-grounds, or taking stock of the old, or just cawing to keep in touch with his fellows. He is very sociable; he has many engagements, now to the woods, now to the fields, now to this valley, now to the next - a round of pleasure or duty all the day 


\section{FIELD AND STUDY}

long. Not given to solitude and contemplation like the proud hawks, not pugnacious, never or rarely quarreling with his fellows, cheerfully sharing his last morsel with them, playing sentinel while they feed, suspicious, inquisitive, cunning, but never hiding; as open as the day in his manners, proclaiming his whereabouts at all hours of the day, looking upon you as the intruder and himself as the rightful occupant. The stiller the day the more noise he makes. He is never a sneaker, never has the air of a prowler. He is always in the public eye or ear. His color gives him away, his voice gives him away; on the earth or in the sky he is seen and heard afar. No creature wants his flesh, no lady wants his plume, though a more perfect and brilliant ebony cannot be found in nature. He is a bit of the night with the sheen of the stars in it, yet the open day is his province, publicity his passion. He is a spy, a policeman, a thief, a good fellow, a loyal friend, an alarmist, a socialist, all in one. Winter makes him gregarious, as it does many men; at night he seeks the populous rookery in the woods, by day he wanders in bands seeking food. In spring he establishes a crow network all over the country and is rarely out of earshot of some of his fellows. How we should miss him from the day! Among our community of birds he is the conspicuous, all-the-yearround feature. We do not love him, there is no poetry in his soul; but he challenges our attention, 


\section{NATURE IN LITTLE}

he is at home in the landscape, he is never disgruntled. Come rain, come shine, come heat, come snow, he is on his job and is always reassuring.

The book of nature is always open winter and summer and is always within reach, and the print is legible if we have eyes to read it. But most persons are too preoccupied to have their attention arrested by it. Think of the amazing number of natural things and incidents that must come under the observations of the farmer, the miner, the hunter, that do not interest him, because they are aside from his main purpose. I see a farmer getting his cows every morning in the early dawn while the dew is on the grass and all nature is just waking up, and think, during the twenty or more years that he has been doing this, what interesting and significant incidents he might have witnessed in the lives of the wild creatures, if his mind had been alert to such happenings! But it was not. He noticed only his cows, or where his fences needed mending, or where a spring needed clearing out. What a harvest Thoreau would have gathered during that score or more of years! From ant to bumble-bee, and from bumble-bee to hawks and eagles, he would have caught the significant things. Rarely can the farmer tell the poet or the naturalist anything he wants to know, because he has not the seeing eye or the hearing ear. The fox-hunter can tell you of the 


\section{FIELD AND STUDY}

foxes he has killed or pursued, and just what it was that turned those that escaped him from their runway, but he can tell you little about the lesser game - what the mice and squirrels are doing, or the chickadees or woodpeckers are saying; his interests lie elsewhere. Downy might be excavating his winter retreat in a dry stub or branch over his head, and he not know it. A chipmunk might be digging his hole in the field the farmer is ploughing in September, and he none the wiser. The poet can say to the farmer: -

\section{"One harvest from the field}

Homeward brought the oxen strong;

A second crop thine acres yield

Which I gather in a song."

And an Audubon or a Fabre would bring home an equal and a different harvest.

Our interest in nature is a reflection of our interest in ourselves; nature is ourselves extended and seen externally. We experience a thrill of interest when we learn that the plants breathe and sleep as we do; that they have ingenious devices for disseminating their seed and for securing cross-fertilization; that there is competition among them and among the trees for the light and air and moisture and the fertility of the soil; that they protect themselves against the sun and the cold, and against the wet. They have all their struggles and their 


\section{NATURE IN LITTLE}

enemies as we do, their youth, their maturity, their ripe old age.

How curious it is that the air-plants should be able to get their mineral elements from the air as if this all but impalpable fluid were a soil full of lime and magnesia and silica, and the plant pushed invisible roots into it! In Florida how often I used to pause and regard them when I saw them growing upon gate-posts or dead tree-trunks and flourishing so luxuriantly! I burned some of them up to see if they left any ashes and was surprised at the amount. Is this semi-tropical air, then, so loaded with all these mineral elements? How much I wished to see the mechanical or chemical devices by which the plants seized it or strained it out of the air! A Russian chemist says that "if a linen surface moistened with an acid be placed in perfectly pure air, then the washings are found to contain sodium, calcium, iron, potassium. Linen moistened with an alkali absorbs carbonic, sulphuric, phosphoric, and hydrochloric acids." The presence of organic substances in the air can be proved by similar experiments. The cosmic dust in the air from the wear and tear of the vast sidereal machinery, not detectable by any of our human senses, may also be a source of some of the mineral elements in the air-plants. It is evidently by the aid of the acids in the leaf that these plants trap and appropriate the iron and the potassium. The atmosphere, then, seems like 


\section{FIELD AND STUDY}

another and finer earth possessing nearly all the mineral and gaseous and living organisms, a finer world superimposed upon the world in which we live. It is the watery vapor in the air, as it is the liquid water in the earth that holds in infinite division the various earth salts upon which the plants feed. An air-plant and an earth-plant, then, do not differ so fundamentally as would at first seem; the former has its roots in the air and draws about the same elements thence that the latter does through its roots in the earth.

Is not distilled and evaporated water supposed to be absolutely free from mineral elements? How, then, do all these minerals get into the air, if not through the vapors that rise from the sea and the land? It is curious, if true, as is alleged, that stagnant water anywhere near air-plants seems to be injurious to them. They need the purest air.

Wait long enough and Nature will always have a fresh surprise for you. I have seen in my life only one big maple-tree utterly destroyed and reduced to kindling-wood by a thunderbolt. I have never yet known lightning to strike a beech-tree, but probably if I wait long enough I shall see it or hear of it. I have only once in my life found a plant called the whorled pogonia, and only once found a plant called the devil's-bit, but in time I hope to find another of each. I have only once seen a wild bird turning over her eggs in her nest as does a hen. I have never but 


\section{NATURE IN LITTLE}

once seen the golden eagle soaring above my native hills and that was seventy years ago. No wild animal of the cat tribe other than the ordinary wildcat had been seen or heard in my native town in the Catskills in my time, till a few years ago, when a new cry was heard. Let me tell about it.

One still, moonlight October night, as I was sleeping on the porch, a bit of natural history on four legs which I had never heard before, let out such a cry and wail, under the hill within a stone's throw below me, that I was startled and puzzled beyond measure. I thought I knew the natural history of the Catskills pretty well, but here was a cry absolutely new to me. There was first a loud, strident, murderous scream, such as a boy might utter when beside himself with fear or pain, followed by a long, tapering moan and wail, like the plaint of a lost soul. It was almost blood-curdling. Five times, with less than half a minute interval, the creature or lost spirit rent the midnight silence with this cry, followed by the wail of utterly hopeless despair. I raised myself up on my elbow and listened. Each scream echoed off in the woods a few hundred yards away, but the moan faded away in the moonlight and became a mere wraith of sound. I could not help visualizing it, and seeing it mount up toward the moon and become fairly blue and transparent in its beams. I was partially disabled from the kick of a horse about whom I had become too coltish in 


\section{FIELD AND STUDY}

the field the day before, and could not get up and run to the brink of the hill, below which the creature seemed to be. What could it be?

The next night it came again at about the same hour, but I was sleeping too soundly to be awakened. A young couple from Kansas were sleeping in the chamber above me; they heard it and were so frightened that they could sleep no more till morning. The next night we all lay awake listening till after midnight, but the performance was not repeated.

Not long afterward I visited the Zoölogical Park at the Bronx and described the sound I had heard to the director. "A puma," he said, "probably one escaped from captivity and calling for her mate." The director had heard them cry hundreds of times and he repeated the cry. "Was it like that?" "Not a bit," I said. "No human voice could give the scream I heard, or imitate the hopelessness of that wail." The only sound that I had ever heard that was at all like the cry was uttered by a young man whom I caught one night stealing my grapes. I suddenly rose up amid the vines, draped in black, and seized him by the leg as he was trying, half paralyzed with fear, to get over the wall. He gave forth a wild, desperate animal scream, as if he had found himself in the clutches of a veritable black fiend. Only the wild animal which slumbers in each of us, and which fear can at times so suddenly 


\section{NATURE IN LITTLE}

awaken, was vocal in that cry. As for the utterly forlorn and heart-breaking crescendo of the midnight wail I heard from my sleeping-porch, I have never heard anything approaching it from man or beast.

There were traditions in the neighborhood of some such mysterious cry having been heard here and there for the past seven or eight years, frightening horses at night, causing them to tremble and snort and stop in the road, and almost paralyzing with fear a young fellow and his girl crossing from one valley to another on their way home from a country dance.

Six years ago, on a warm July night, a woman friend of mine and her son, of sixteen or eighteen, were passing the night in hammocks in my orchard, when near midnight they came hurrying to the house in a great state of agitation; they had heard a terrible, blood-curdling cry. I laughed at them as city tenderfeet, told them they had probably heard the squall of a fox, or the cry of an owl, or a coon. They did not care what it was, but they would not return to their hammocks, or even try to pass another night there. They have since told me that the fearful cry they heard was like the one I described.

An old woodsman and hunter has told me that I heard the cry of the Canada lynx. And he is probably correct, though I can find no record in the books that the lynx has such a cry. In the winter of 


\section{FIELD AND STUDY}

1915 a similar cry was heard late at night on the hills above the village. It set all the dogs in town barking and people thrust their heads out of their doors and windows to see or hear what had caused the sudden rumpus. The following September, while a young man whom I know was ploughing in a hill field near the woods, a large, yellow, catlike animal came down and lingered near him. His description of it, including the fact that it had a short tail, convinced me, that he had seen a lynx and that this was our mysterious night screamer. The young farmer ran to the house to get his gun, but when he returned he saw the big cat disappearing in the woods. Yet no one has seen its track upon the snow, and no poultry or lambs or pigs or calves in the neighborhood have been killed by it.

One need never expect to exhaust the natural history of even his own farm. Every year sees a new and enlarged edition of the book of nature, and we may never hope to turn the final leaf. 


\section{VIII \\ THE INSECT MIND}

$7 \mathrm{HE}$ insect mind is just as obvious as the mind 1 of the four-footed creatures. Darwin thought the most marvelous bit of matter in the universe was the brain of an ant. Fabre's studies have thrown more light upon the workings of the insect brain than those of all other investigators, though George and Elizabeth Peckham, of Wisconsin, have thrown the same flood of light upon the lives of our social and solitary wasps. Their volume upon this subject can go on the same shelf with the works of "the insect's Homer," as Maeterlinck called Fabre.

Fabre is rather the insect's Sherlock Holmes. Not a secret of their lives, seemingly, escapes him; he unravels the most intricate problems of their lifehistories; his patience is tireless, his powers of observation unequaled, and his scientific method without a flaw. So many of the secrets of insect lives, especially of the wasps and beetles, are underground, yet Fabre knows them all. He is an eavesdropper, a "Paul Pry," a skilled detective; he knows even the hidden crimes and scandals of the insects. If he does not get the secret he is after this year, or the next, he follows up the clue five, six, or seven years, at times sitting so long by the roadside, or amid the vines and bushes, - often all day, - without chang- 


\section{FIELD AND STUDY}

ing his place, that the peasants, as they go to and fro, from their work, tap their heads significantly to one another, and exclaim, "Pécaïre!"

Fabre reveals a world at our feet which we rarely or never see, but which is in many ways a copy in miniature of the human world in which we live its arts, its economies, its thefts, its murders, its struggles, its competitions, its failures, its providences, its love of home and of offspring, and its relations to time and chance. Of the insects he says:

They become past-masters in a host of industries for the sake of a family which their faceted eyes never behold and which, nevertheless, the maternal foresight knows quite well. One becomes a manufacturer of cotton goods and mills cotton-wool bottles; another sets up as a basket-maker and weaves hampers out of scraps of flowers; a third turns mason and builds rooms of cement and domes of road-metal; a fourth starts a pottery works, in which the clay is kneaded into shapely vases and jars and bulging pots; yet another adopts the calling of a pitman and digs mysterious warm, moist passages underground. A thousand trades similar to ours and often even unknown to our industrial system are employed in the preparation of the abode. Next come the victuals of the expected nurslings: piles of honey, loaves of pollen, stores of preserved game, cunningly paralyzed. In such works as these, having the future of the family for their exclusive object, the highest manifestations of the instinct are displayed under the impulse of maternity.

Fabre convinces himself and his reader that the insects do not reason, yet he reveals in them some- 


\section{THE INSECT MIND}

thing like superhuman knowledge. We have no name for it but instinct, - untaught wisdom, - but in some cases it is so far beyond anything that man attains to, except after long research and experimentation, that we marvel at it as we would at the supernatural. The knowledge that the hunting wasps possess that the spiders and crickets and beetles which they bring and store up for their young, as yet unhatched, must be paralyzed but not killed, - their animal life, as Fabre calls it, destroyed, but their vegetative life left intact, how far it transcends anything we know until we call to our aid all the resources of experimental science!

Fabre shows us one species of wasp striking unerringly at the one minute vulnerable point in the breastplate of its prey, a species of beetle. It seems to possess an anatomist's knowledge of the structure of its game, and of the physiological function of its nerve ganglia. With one species of beetle it knows that one thrust of the sting is sufficient; with a species of cricket whose main nerve-centres are three and are more widely distributed, it knows that three stabs are required, and it knows precisely where to administer them. How marvelous it all is! The divinity that so carefully fitted a coat of mail to the beetle left one vulnerable point, and then betrayed the secret to its deadly enemy, the wasp.

Fabre has seen the wasp seize the beetle, press 


\section{FIELD AND STUDY}

"her forefeet violently upon the beetle's back, as if to force open some ventral joint," then curve her body around under the insect's belly and thrust her sting into a minute opening between its first and second pair of legs!

O strange and baffling Nature! Truly thy ways are not as our ways. But Nature keeps the game of life going, which seems her main purpose, making it as various and picturesque as possible. She divides her favors pretty equally, but not quite; she leaves enough difference up or down to keep the currents going. She is just as much interested in the weevil as in the wasp, and though she has armed the wasp to slay the weevil, she has made the weevil more prolific, and given it life on easier terms. The hunted usually has life on easier terms than the hunter - a wider choice of food and of territory, and other compensations. It is rarely that a rat or a chipmunk or a rabbit can escape the weasel when the latter gets on its trail, and yet there are hundreds of rats and chipmunks and rabbits to one weasel. Some unknown factor operates to keep the latter in check.

Our prudence, our economy, our selection, our short cuts, find no parallel in Nature's works; and for the reason that her special ends are all inside of general or universal ends: so careless of the individual, as Tennyson says, and so careful of the type. Behold how Nature equips one animal to prey upon 


\section{THE INSECT MIND}

another, and then equips that other to escape its enemy. The rabbit has no defense but its speed and its sleepless eyes, yet these suffice. The animals that are the prey of the stealthy cat tribe are almost preternaturally alert and keen of eye and scent. Nature has told them who is shadowing them.

The intelligence of Nature outside of man consists largely in adapting a means to an end, and the end is foreshadowed in the organization. Propose to an animal a new end, not in line with its instinctive activities, and it is helpless. This is markedly true in the insect world; their activities are like the activity of your watch, which ticks off the hours in orderly sequence, but which cannot tick off one second in the opposite direction.

"To know everything and to know nothing," says Fabre, "according as it acts under normal or exceptional conditions: that is the strange antithesis presented by the insect race," and he might have added, "by nearly all the lower orders of animal life." Inside the field of their instinctive activities their wisdom is truly astonishing; outside that field their ignorance and stupidity are equally astonishing. An animal must know certain things in order to survive and perpetuate itself, or rather we should say, it must perform certain acts in order to survive - whether or not it knows what it is doing, as we know, is a question.

The wasp that is such a skilled surgeon hauls its 


\section{FIELD AND STUDY}

prey to its den by laying hold of some appendage of the head, as the antennæ or the palpi. Remove these after the wasp has brought its game to its door, and the little automaton is powerless to complete its job. It could just as easily haul its beetle in the hole by the leg or the ovipositor, - that is, backwards, instead of head first, - but this it has never done; it is not so written in the tablet of its mind; the game must go in head foremost. In such a predicament the wasp hesitates, washes its face and eyes, seems to reflect a moment, then tries to seize the game by the head, but her mandibles slip off the polished skull, and she finally abandons the task as hopeless and goes away in quest of a new victim.

Fabre interrupted this same species of wasp when it had stored its game in its hole and was stopping up the entrance and preparing to leave it forever. He opened the hole with his penknife and removed the beetle while the wasp stood looking on. When he had finished, the wasp reëntered her den, inspected it carefully, as in the first instance, and then proceeded to close it up as before, with great care and deliberation. That her game, and the egg she had laid upon it were gone, made no difference; she must follow out the programme, one act must follow another in its proper order.

The wasp always explores her hole the last thing before hauling in her game, and if you interrupt the 


\section{THE INSECT MIND}

order of her activities she will do this over and over; she cannot omit one of the links in the fatal chain that binds her deeds together, nor change their order.

A wasp, so clever in all her natural ways, is foolish when these ways are in'erfered with. She makes a burrow in the soil several inches long, the entrance to which is always hidden by the sliding down of the sand in which the tunnel is made. She finds this entrance unerringly when Fabre himself cannot detect the slightest clue as to its exact whereabouts. But unless she can enter this tunnel at the regular door, she does not know it from any other hole in the ground, and, stranger still, she does not know her own grub asleep at the end of it; she runs over it or pushes it about, looking for the entrance that should guide her to it. The wasp knows her young only as the end of a series of acts that must follow one another in a regular order. And then she does not know it in our human sense: she is a stranger in her own house if you admit her through an opening you have made instead of through the door which she made.

The intelligence of the insect is the intelligence of Nature - it is action and not reflection. Nature lives and grows, and does not pause to cogitate and ask the reason why, as we do. Her works are a perpetual revelation. Fabre can give good and suffcient reasons for every procedure of his insects, but 


\section{FIELD AND STUDY}

he knows full well that the insect does the deed without thought or previous experience.

The Sphex wasp seems to know that the cricket upon which it preys has three nerve-centres that control its main movements, and hence requires three stings in three different parts of its body to produce complete paralysis, while another species of wasp, the Cerceris, knows her beetle has only one nerve-centre, and hence she stings it but once.

The wasp called the Ammophila sometimes pinches and bruises the brain of the grub she has stung and is carrying to her nest, in order to increase its torpor, but Fabre says she knows just where to stop; she "knows quite well that to inflict a mortal wound on the cervical ganglia would mean killing the caterpillar then and there, the very thing to be avoided." Of course, the wasp knows nothing about nerve-ganglia and their functions. This is the untaught wisdom of her race, of which she is the unwitting instrument. It is an ancestral knowledge which Nature infused into her organism before she was born.

The Sphex wasp needs at times to paralyze the mouth-parts of the game she is carrying to her den, so that it cannot impede her progress by seizing upon blades of grass by the way, and also that she may lessen the danger of the beetle's seizing and wounding her with its mandibles; and, like a trained surgeon, she knows the precise spot in the beetle's 


\section{THE INSECT MIND}

head in which to insert her sting to produce the desired effect. Truly such science as this cannot be found outside the insect world.

Fabre says that bees have a topographical memory that grasps the map of the country, but not the beloved nest, the home itself. The bee will find the locality of its nest from the verge of the horizon, yet when the nest itself is laid open, she does not recognize it; she can find the entrance door unerringly, and that is enough for her. Exchange the nest of the mason bee for that of another of the same species, and she does not know the difference. If the cell she was working on is half-finished, and you place a completed one, flled with honey, in its place, the bee goes on with her masonry on the filled cell just the same; or, if you reverse this process, and put a half-finished cell in the place of the finished one, she goes forward with her honey-storing in the incomplete cell. She cannot stop her masonry, or her honey-gathering, till her machinery, wound up for that special purpose, has run down. In one instance Fabre punched a hole in the bottom of a cell the bee was filling, so that the honey ran out as fast as she put it in. The bee seemed a little surprised at the behavior of the thing, hesitated a little, and then went on with her work, and in due course sealed up the cell, empty though it was, as the programme demanded.

Fabre thinks, and apparently proves, that the 


\section{FIELD AND STUDY}

female wasp can at will determine the sex of her egg at the instant of laying. Here again we see her superhuman knowledge. She can begin with eggs that will produce males or females, just as she chooses, and since she cannot change the order of their succession in her ovaries, she must determine their sex by the power of her will at the time of laying. Since the females require more space and more food than the males, the mother must know the sex of the egg which she is going to lay while in the act of laying it.

The hive bee can change the sex of the egg turn a worker bee into a queen bee - by changing the size and position of the cell, and changing the food in quantity and in kind. Something like this may take place in the case of the wasp referred to.

Insects of all kinds possess the knowledge and skill that it is necessary for them to have. Thus "the leaf-roller requires for her young a leaf rendered flexible ad hoc, half-alive, paralyzed in a fashion, a leaf that can be easily shaped into a scroll," and she knows just what to do to attain this end, as well as the wasp knows how to paralyze her cricket or spider - she inserts her drill into the petiole of the leaf, there and nowhere else, and thus without much trouble she affects the resin of the aqueduct.

Different species of insects at times display the most amazing ignorance in regard to their natural 


\section{THE INSECT MIND}

enemies. None of them, save our hive bee, seems to know the parasites that destroy their brood; apparently they make them welcome in their homes, thus acting the part of Nature, who is just as much interested in the success of the parasite as in that of the host. The Halictus moth seals up the cell in which her brood has been destroyed as carefully as she does the others, when she is only sealing up emptiness. The spider is wise when all insects are wise, and stupid when all insects are stupid. She has eight gleaming eyes, but they do not serve her to tell her own ball of eggs from that of another of different shape and structure. She will accept a ball of cork in lieu of her own, embrace it lovingly, fondle it with her palpi, fasten it to her spinnerets, and drag it away. Between her own ball and one of cork placed side by side on the floor she apparently has no choice, and will take the one she reaches first. From amid four or five cork balls she rarely selects her own, but snaps up a ball at random. A ball she must have; it is so written in the bond; but as to which one, what matters it?

"The insects," Fabre says, "have a calendar of their own. At a given hour suddenly they awaken, as suddenly afterwards they fall asleep. The ingenious becomes incompetent when the prescribed hour is ended." 


\section{IX}

\section{A CLEVER BEASTIE}

T NEVER seem to tire of writing and talking 1 about the chipmunk. He is a friend of my boyhood. When I saw one last winter down in Georgia, I felt as if we were exiles together, but he was probably much more at home in that fenceless country than I was.

The chipmunk is undoubtedly the best-beloved of all our lesser rodents, and more persons probably have friendly intimacies with him than with any other of our four-footed wild creatures. He is such a pretty little animal, so bright, so alert, so clean and well-groomed, not a hair missing or out of place; and the penciled lines on his back are so distinct and pleasing - seven lines, two pairs of three each, one light and two dark, on either side, with a dark line between them running down the middle of the back. None other of our little rodents has such a pretty coat or such pretty ways, and no other is so harmless about our homes and farms.

During my youth in the Catskills, when there were at least ten chipmunks where there is only one now, he was usually pretty hard put to it for food in May and early June, and was at times guilty of digging up the newly planted corn. When the sprouts 


\section{A CLEVER BEASTIE}

were an inch or so high, he would occasionally raid the rows of corn near the stone walls. With the depredations of the crows in the middle of the field and of the chipmunks along the borders, some seasons the corn suffered badly.

Many a time when I was a boy of ten or twelve my father armed me with an old flintlock musket and sent me forth to "shoot the chipmunks round the corn." Sometimes the old gun would be loaded with hard peas or small gravel-stones, and at only six or seven yards' range the head of the poor chipmunk peering from the wall was pretty sure to receive a fatal wound. I do not remember that I then had any pity for him. In fact, I think I rather enjoyed the sport of hunting him. That is the boy of it. Needless to say, I could not do such a thing now.

Last summer the rats raided my garden and destroyed scores of the ears of my Golden Bantam corn. They would climb up the stalks at night and strip off the husks like raccoons, and leave only the cobs. I set traps in their runways baited with corn, and caught a dozen or more of them; but one afternoon, to my dismay, I found two chipmunks in the traps. The mishap pained me so that I took the traps away and let the rats have full swing. The chipmunks had been lured by the corn that I had scattered over the ground and placed on and under the pans of the traps. 


\section{FIELD AND STUDY}

The chipmunk is a ground-dweller and a worker in soils, but no tree-dweller is more bright and tidy. His tail is as clean and perfect as if it had never been whisked in and out of a hole in the ground times without number. He carries it so deftly and gracefully when he makes a dive for his hole that apparently not a hair of it ever comes in contact with the soil. You are not surprised to see his face so clean, because he is washing it on all occasions. His sanitary regulations in his den also seem to be wisely looked after. He stores up nothing that would ferment or mildew - only dry-cured food. He will eat the green corn that you give him and add the dry kernels to his winter stores.

At my summer home in the Catskills, called Woodchuck Lodge, I cultivate friendship with the chipmunks, but rather frown upon the red squirrels, which are much more aggressive and destructive about the orchards and farm buildings. Besides, they are so impish and defiant that they do not win your heart as do the chipmunks.

The red squirrels and the gray come and go, but the gentle chipmunk we always have with us. He loves the open country, where the stone fences give him lines of communication. He has a curious habit, when he sees or hears a wagon or car coming, of suddenly running across the road in front of it. I can offer no explanation of this behavior unless it be that the apparent hazard of such a dash affords him 


\section{A CLEVER BEASTIE}

a little excitement that he relishes. I find more of their dens along highways than anywhere else.

The chipmunk is one of the most provident of our wild creatures. Neither the red nor the gray squirrel regularly stores up a winter supply of food, although at times the red seems to do so in a tentative, uncertain kind of way, but not with the unmistakable provident purpose of the chipmunk when it stores up food. You will see both of them in the fall carrying nuts from the trees and hiding them here and there under the leaves and grass, but it is doubtful whether they ever seek them again for food. What they are really doing is unwittingly planting oak and chestnut and hickory trees. Nature seems to utilize their love of nuts for her own purpose, as she does that of the crows and jays.

But the chipmunk is rarely a tree-planter. $\mathrm{He}$ is absorbed in his own economies. He has two capacious cheek pockets that are invaluable to him, and those pockets have a power that ordinary pockets do not possess - the power of deglutition, and also the power to reverse the process. The pockets literally swallow the grains and nuts and as literally disgorge them. An acorn or other nut too large for his pockets the chipmunk carries in his teeth.

Early in the season, or as soon as he can find any ripened seeds, the chipmunk begins to provide for his winter needs. In my morning walks I usually 


\section{FIELD AND STUDY}

take a few handfuls of mixed grain in my pocket and distribute it here and there along the stone walls near where I know my little friends have their homes. They soon "catch on," as the boys say, and the sight of me raises expectations among them. After a little time they allow me to come within a few yards of them, showing only an unusual eagerness and curiosity. Then as I move on they quickly gather up the wheat and corn and carry it to their dens.

The recipients of my bounty seemed to excite the jealousy of the chipmunks that lived farther away, or off the line of my walks. I had often wondered whether animals of the same kind ever plundered one another's stores. I had believed that they did not, but last fall, under the unequal conditions that I established by my limited bounty, I discovered that they did. On three occasions I saw chipmunks raiding their neighbors' stores. From the relative size of the robbed and the robber in two cases that I observed, I got the impression that the male was the robber in one case and the female in the other.

For two years a chipmunk has had a den by the roadside near the stone wall in front of my house, and many a handful of wheat and buckwheat and Indian corn have I placed upon the wall for her, if it is a "her." In July she began to make long trips up and down the stone wall, returning to her den with full pockets, so that by mid-October I con- 


\section{A CLEVER BEASTIE}

cluded that with her own harvests and the additions from my granary her stores were considerable.

One morning I happened to see a chipmunk, larger and a little lighter-colored than my neighbor across the way, come down out of the orchard, cross the road to the wall, and quickly work his way down to her den, which he boldly entered. I had just seen the rightful owner go off down the wall the other way, but in a moment she came back and entered her hole.

"Now there will be trouble," I said to myself.

In a few seconds there was a yellow streak out of the hole, and two chipmunks were spinning along the wall at their best speed, the larger one keeping about a yard ahead. I could see that the leader had something in one cheek pocket. It is curious that on such occasions, among both birds and animals, the thief, no matter if he is the larger and stronger, will always flee. A guilty conscience seems to make cowards of all creatures, and a sense of right emboldens the weakest.

My plucky little neighbor pursued the intruder until I lost them from sight. That she compelled him to disgorge I can hardly believe. When she returned, five or six minutes later, she fell to eating the kernels of green corn that I had placed upon the wall in front of her den.

A quarter of an hour later I saw the thief coming cautiously along the wall, as if bent on making 


\section{FIELD AND STUDY}

another raid. He paused every few yards to see whether the coast was clear. My little unsuspecting friend, enjoying the sweet corn, was completely hidden from him behind a big stone on the top of the wall. The robber came near and slanted his course down the side of the wall to the ground near the hole. From this point he must have seen the owner of the den, for he turned hurriedly back up the wall and disappeared.

Some time later I saw him coming back along the wall again. His approach was very cautious and hesitating, just as yours or mine would be if we were bent on such an errand. He skulked along the side of the wall; he paused behind stones; he peered toward the den - every act betrayed guilt and trepidation. I had seen his intended victim enter her den, but he had not, and I could see that he was in a quandary as to whether or not she was at home.

As he neared the den, he got off the wall some yards away, and came cautiously along in the grass, pausing and watching. Finally he reached the hole, and hesitated there for some seconds. Three times he raised his head and glanced round; then he disappeared.

"He is in," I said, but had barely said it when out shot the yellow streak again and went coursing up the stone fence as before. It was nip and tuck, but the robber kept ahead. My neighbor was gone so long this time that I began to fear she had come to 


\section{A CLEVER BEASTIE}

grief; but at last she came scurrying back. Whether or not her little earth castle was ever assaulted again by the brigand from the bush I do not know.

On both sides of my camp in the orchard, and not more than fifty feet apart, two chipmunks had their dens, and here I chanced to see one of them rifling the stores of the other. This time I got the impression from the slight difference in size that the robber was a female, but I am not certain. I had fed both of them freely, but the female was the tamer and gentler. She learned to come into my bush tent and to pick up the grain at my feet, and finally to take it from my hand. In going home with her ill-gotten gains from her neighbor's stores, she did not trust herself on the ground, but took a course through the apple-trees and across the canvas roof of my camp, and into her den that way.

On one occasion I saw a chipmunk waylay her in one of the apple-trees and make a savage drive at her, but whether or not it was the owner of the stores she was pilfering, I do not know. Chipmunks all look so near alike that it is not always easy to tell who's who in that community.

In a den that a chipmunk excavated one September in a bank by the roadside I witnessed another case of house-breaking. I saw a chipmunk enter the hole when I knew the owner was at home. I bent my ear above the ground for a moment to take in, if I could, what was said. I soon heard an 


\section{FIELD AND STUDY}

angry altercation there under the sod - tones of complaint, but not of pain. Presently a head popped up, evidently urged from behind, but it dropped back on seeing me so near. Then it hastily appeared again, and as I withdrew a few paces, the chipmunk shot out and fled.

This nest was very artfully excavated. Instead of the pile of freshly dug earth that usually attracts the eye where a chipmunk has recently been at work, there was only a little curtain of earth on the side of the bank, strung along four or five feet with a roll of grass and moss above it, and fading off into the soil of the bank that the road-menders had exposed. Only the eye of a passer-by looking for such signs would have noticed it. It was as if the squirrel had had a little tramway a few feet long at the top of the bank under the roll of moss and turf, and had dumped his newly dug earth from that and let it stream down the bank until it found the angle of repose. The entrance was a clean-cut hole hidden in the grass on the top of the bank.

When one chipmunk receives favors in the way of extra food, all his neighbors seem to find it out, and, I suspect, make an effort to equalize things a little. One season I tried to find out whether a chipmunk's provident instinct would get the better of his prudence and lead him to add to his stores until he had no room left in his den for himself. I supplied a greedy fellow with about a peck of hickory-nuts, 


\section{A CLEVER BEASTIE}

chestnuts, corn, cherry-pits, and peach-pits, and I saw him carry every nut and kernel of grain into his den.

How hurriedly and exultantly he worked, as if he had feared that this great windfall might be all a dream, or that his neighbors might want to share it!

Well, I am compelled to believe that his neighbors did share it, but just how and when I do not know. I saw the nuts go into the den, a plump peck of them, and I marveled at that den's capacity. I had dug out two chipmunks in their winter retreats, and neither den was large enough to hold much more than four quarts and leave breathing-room for the occupant and space for his nest.

It is true that in excavating his retreat the chipmunk had brought to the surface a bushel of earth. I had measured it; but probably more than half of this amount had come from the three tunnels five or six feet long that led out from the central chamber. The chipmunk in the Catskills goes down just below the frost line, - in the open fields a little more than three feet, - but his tunnels are very crooked. If any fresh earth had appeared at the surface I should have thought that my little fellow worked nights enlarging his quarters to meet the sudden and extraordinary supply of food; but no soil appeared.

It is certain that one chipmunk for once in his life 


\section{FIELD AND STUDY}

had his fill. At the last he began to hesitate, and to hide some of the hickory-nuts here and there in the grass. I was tempted to dig into his chamber at once, but it seemed such a pity to bring rack and ruin on his house just on the threshold of winter that I deferred my investigation until spring. Then I breached his walls, and to my amazement I found the usual small vault such as I had found before, and only a few empty shells of hickory-nuts and chestnuts - not a double handful in all. It seemed as if my fall observations must have been a midday dream. It was all incredible.

The owner was not at home when I forced his dwelling, but he had evidently passed the winter there. But where did he store all those nuts and what had become of them? His neighbors must have decided to share them with him.

A couple of feet from the old entrance I found a new one. In all cases of dens that I have had under observation during the fall, I have noticed that new entrance the next spring. They are all made from beneath. What becomes of the soil that the chipmunk must remove in making the new hole is one of the mysteries I have not yet cleared up. There is no sign of it at the surface.

The other question that long puzzled me - the holes that had no pile of earth, old or new - I think I have solved: they are the entrances to old dens that have had their pile of fresh earth near by, 


\section{A CLEVER BEASTIE}

which time and the elements have obliterated. But what has become of the excavated earth of the new spring entrances, which in some cases must be from a tunnel eight or ten feet long, is still a mystery.

If my reader can surprise a chipmunk digging his hole, as I did last September, he will be very lucky. No doubt he has found along the road or on the borders of the woods a fresh pile of earth, usually about a bushel of it, with a clean-cut hole down through the turf near it, and with not a grain of soil, or any sign of a path between the pile of earth and the hole. If he investigated, he may, in some cases, have found in the pile of soil one or more earthstained stones that he could not put back into the hole out of which they appeared to have come. There is no deception or sleight-of-hand about it those stones actually came out of the ground with that pile of earth. But the hole out of which they came is plugged up and covered up by the pile of earth and is no longer used. They did not come out of the obscure hole which is now the only entrance to the den. 


\section{X \\ PHASES OF ANIMAL LIFE}

TO doubt there are tides in the affairs of our 1 wild neighbors no less than in the affairs of men - vicissitudes of fortune that affect not merely individuals, but whole tribes and races. I noticed the past season in widely different parts of the country that the goldfinches did not breed as freely as they usually do. Not one nest could I find in the orchards or bushy fields of the home farm, where, the season before, I had found half a dozen. What was the matter? The old birds were there, and the thistles bloomed as usual, but no nests could be found, and only two or three young birds were seen in August and September, where I used to see and hear scores of them. What caused the ebb in the tide of goldfinch life? Some other season may bring the flood, as it has in the case of our pretty little rodent the chipmunk. For twenty years or more the chipmunks have been slowly disappearing from all parts of the country with which I am familiar; hardly one of late years where there used to be ten when I was a boy. But suddenly last year they began to be noticeable, and the present season they are here in something like their old-time numbers. I hear of them from different parts of the State - the 


\section{PHASES OF ANIMAL LIFE}

result of migration, I was at first inclined to think, till John Lewis Childs told me they had become suddenly numerous on Long Island. This fact seems to exclude the idea of migration from some other part of the country. Some parasite, some plague chipmunk smallpox, or cholera - may have kept their numbers down for years, when suddenly the enemy vanishes and the race recovers its lost ground.

These vicissitudes, these ebbs and flows, probably run all through the life of nature about us and we observe them not. I know an ash-tree by the roadside that year after year, carly in the season, lost part of its foliage by some form of leaf-blight. Surely, I thought, that tree is doomed; then there came a season when the blight did not appear, and it has not appeared since. A few years ago the elm-beetle threatened to destroy all our elms here on the Hudson; then it met with a check and seems now to have gone out entirely. A species of forest-worm denuded the sugar maples in large sections of Delaware County, and spread like fire from one wood to another, and grew more and more devastating; then a parasite, a species of ichneumon-fly, took a hand in the game, and in one season the tide ebbed and has never returned.

A year or two later another species of forest-worm appeared in the same section of the country and stripped the beeches; in midsummer the woods were 


\section{FIELD AND STUDY}

full of white moths for two seasons; then something happened and these worms have not returned.

Occasionally a favorable combination of weather and seasonal conditions fills some parts of the country with a plague of grasshoppers, and the farmers tremble for their next season's crops, but the next season may prove quite grasshopperless.

The tide in the affairs of some of our fruit and tree pests, such as the gypsy and brown-tailed moths and the San José scale, seems yet at its full, but no doubt the ebb will come before the case is hopeless.

Ebb and flow, ebb and flow, everywhere in the life of nature. When I lived upon the Potomac forty years ago, the grass bunting, or dickcissel, was a common bird in the fields. Some years later these birds began slowly to disappear, and now that part of the country is said to be destitute of them, while they are common farther south in Kentucky and Tennessee. What caused the disappearance or migration of these birds, who knows?

Of late years the prairie horned lark has appeared upon my native hills in the Catskills, where, in my youth, they were never seen. Such game-birds as the quail ebb and flow in New York and New England, according as the winters are mild or severe. Not many years ago a series of mild winters gave the quail a great lift in the Hudson River Valley, where I live. The call of Bob White lent a new charm 


\section{PHASES OF ANIMAL LIFE}

to the spring fields. Then came two or three very severe winters and the cheery call of the quail is heard in our fields no more. The same severe winters cut off the race of 'possums, which had multiplied in our country till they were as common as rabbits. A few years ago there was a fearful ebb in the life of the ruffed grouse, all over the country from Maine to Minnesota. More than fifty per cent of the birds vanished in a single season. The cause of it has not yet been cleared up. Now the birds are slowly reappearing.

The natural balance of life in any field cannot long be disturbed. Though Nature at times seems to permit excesses, yet she sooner or later corrects them and restores the balance. The life of the globe could never have attained its present development on any other plane. A certain peace and harmony have come out of the perpetual struggle and warfare of opposing tendencies and forces.

The waters of the globe all tend to seek the same level, but this equilibrium is constantly broken by the solar forces, so that the currents flow perpetually. When one force pulls down, another force builds up.

The weasel is the most fierce and bloodthirsty of all our smaller mammals; mice and rats, squirrels and rabbits, and birds vanish before him, yet he does not overrun our fields and woods; he is quite a rare beast; some unknown enemy or condition 


\section{FIELD AND STUDY}

keeps him in check. The defenseless rabbit, upon which so many creatures prey, easily holds its own because it is so very prolific. It also has another advantage; it can and does sleep with its eyes open. The flying squirrel would seem to have a great advantage over the chipmunk, yet it is far less numerous in our woods; it pays for its wings in some way; it is probably less handy and resourceful. Few animals will molest the skunk, yet the world is not filled with skunks; where they are found side by side, the woodchuck, which has many more natural enemies, is far more abundant, not because it is more prolific, which does not seem to be the case, but because, among other things, its food-supply is simpler and more universal. The limitation of the natural food-supply is, of course, the great factor in the limitation of animal life everywhere. If our spring is late and cold, the robins nest later, and have smaller broods than during a warm, early spring.

The gray squirrel is far less numerous in my locality than the red because, in my opinion, he is far less resourceful; he is not the same miscellaneous feeder, and hence is much more restricted in his range. The red squirrel, when hard put to it, will come to your very door and chip up green apples and pears for the meagre supply of seed in them. In May and June, when other supplies fail, he helps himself out with birds' eggs and with young 


\section{PHASES OF ANIMAL LIFE}

birds, and in the colder seasons he raids the granaries of the wild mice and the dens of the chipmunks. He is a hustler and a freebooter at all times. His natural enemies are black snakes, weasels, hawks, owls, and cats, yet his tribe seems to be increasing.

Man, of course, disturbs the balance of Nature wherever he goes. Some forms of life disappear before him, while others thrive and increase in his footsteps. He adds greatly to the food-supply of some species, while he cuts off that of others. Most of the field animals partake of his bounty, but the forest animals vanish before him. That any species has actually become extinct through his instrumentality, unless it be that of the passenger pigeon, may well be doubted, though he hastened the extinction of the great auk, and, maybe, the Labrador duck. The buffalo would have become extinct under his ruthless slaughter, had he not stayed his hand in time. Whole tribes and races of animals, some of them fearfully and wonderfully made, became extinct in geologic time, long before man could have played any part in hastening their doom. A change in their environment, through slow crustal movements of the earth, or through change of climate that affected their food-supply, probably rendered them unfit to survive. 


\section{XI}

\section{EACH AFTER ITS KIND}

T OW sharply most forms of life are differenti1 ated! The die that stamps each of them is deeply and clearly cut. As I sit here in my bush camp under the apple-trees, I see a chipmunk spinning up the stone wall a few yards away. His alert eye spies me, and he pauses, sits up a few moments, washes his face with that hurried movement of his paws over it, then hesitates, turns, and goes spinning back down the stone fence. He seems to sniff danger in me. He is living his life, he has a distinct sphere of activity; in this broad, rolling landscape he is a little jet of vital energy that has a character and a purpose of its own; it is unlike any other. How unlike the woodchuck in the next field, creeping about the meadow, storing up his winter fuel as fat in his own flabby body, or the woodpecker on the apple-tree, or the noisy crow flying by overhead! Each is a manifestation of the psychic principle in organic nature, but each is an individual expression of it. The chemistry and the physics of their lives are the same, but how different the impressions they severally make upon us! Life is infinitely various in its forms and activities, though living things all be made of one stuff. 


\section{EACH AFTER ITS KIND}

Soon after the chipmunk there appears a red squirrel going down the wall - half-brother to the chipmunk but keyed to a much higher degree of intensity. He moves in spasms and sallies and is frisky and impish, where the chipmunk is sedate and timid. His arboreal life requires different qualities and powers; he rushes through the tree-tops like a rocket; he travels on bridges of air; he is nearly as much at home amid the branches as are the birds, much more so than is the flying squirrel, which has but one trick, while the red squirrel has a dozen. That facile tail, now a cockade, now a shield, now an air-buoy; that mocking dance, those derisive snickers and explosions; those electric spurts and dashes - what a character he is - the very Puck of the woods!

Yesterday a gray squirrel came down the wall from the mountain - a long, softly undulating line of silver-gray; unhurried, alert, but not nervous, pausing now and then, but striking no attitudes; silent as a shadow and graceful as a wave - the very spirit of the tall, lichen-covered birches and beeches of the mountain-side. When food is scarce in the woods he comes to the orchards and fields for insects and wild fruit, and any chance bit of food he can pick up. What a contrast he makes to the pampered town squirrel, gross in form and heavy in movement! The town squirrel is the real rustic, while the denizen of the woods has the grace and 


\section{FIELD AND STUDY}

refinement. Domestication, or semi-domestication, coarsens and vulgarizes the wild creatures; only in the freedom of their native haunts do they keep the beauty and delicacy of form and color that belong to them.

A nuthatch comes upon the apple-tree in front of me, uttering now and then his soft nasal call, and runs up and down and round the trunk and branches, his boat-shaped body navigating the rough surfaces and barely touching them. Every moment or two he stops and turns his head straight out from the tree as if he had an extra joint in his neck. Is he on the lookout for danger? He pecks a little now and then, but most of the food he is in quest of seems on the surface and is very minute. A downy woodpecker comes upon the same tree. His movements are not so free as those of the nuthatch. He does not go head foremost down the tree; his head is always pointed upward. He braces and steadies himself with his tail, which has stiff spines at the ends of the quills. By a curious gymnastic feat he drops down the trunk inch by inch, loosing his hold for a moment and instantly recovering it. He cannot point his beak out at right angles to the tree as can the nuthatch. In fact, he is not a treecreeper, but a wood-pecker, and can penetrate fairly. hard wood with his beak. His voice has a harsh, metallic ring compared with that of the soft, childlike call of the nuthatch. His only contribution to 


\section{EACH AFTER ITS KIND}

the music of the spring is his dry-limb drum with which he seeks to attract his mate when the love passion is upon him.

Oh, these wild creatures! How clear-cut, how individual, how definite they are! While every individual of a species seems stamped with the same die, the species themselves, even in closely allied groups, are as distinct and various in their lineaments and characteristics as we can well conceive. Behold the order of rocients, including the squirrels, the hares, the rabbits, the woodchucks, the prairie-dogs, the rats and mice, the porcupines, the beavers - what diversity amid the unity, what unlikeness amid the sameness! It makes one marvel anew at the ingenuity and inventiveness of Nature - some living above ground, some below, some depending upon fleetness of foot and keenness of eye for safety, some upon dens and burrows always near at hand; the porcupine upon an armor of barbed quills, the beaver upon his dam and his sharpness of sense. If they all descended from the same original type-form, how that form has branched like a tree in the fields dividing and dividing and dividing again! But the likeness to the tree fails when we consider that no two branches are alike; in fact, that they are as unlike as pears and peaches and apples and berries and cherries would be on the same tree - all of the same family, but diverging widely in the species. 


\section{FIELD AND STUDY}

The ground-dwellers, such as woodchucks and prairie-dogs and gophers, have many similar habits, as have the tree-dwellers and the hares and rabbits. That any of these rodent groups will branch again and develop a new species is in harmony with the doctrine of evolution. But these evolutionary processes are so slow that probably the whole span of human history would be inadequate to measure one of them.

Nearly all the animal forms that we know are specialized forms, like our tools and implements shaped for some particular line of activity. Man is the most generalized of animals; his organization opens to him many fields of activity. The woodpecker must peck for his food, the kingfisher must dive, the flycatcher must swoop, the hawk must strike, the squirrel must gnaw, the cat must spring, the woodcock must probe, the barnyard fowls must scratch, and so on, but man is not thus limited. His hands are tools that can be turned to a thousand uses. They are for love or war, to caress or to smite, to climb or to swim, to hurl or to seize, to delve or to build.

The organization of most animals has special reference to their mode of getting a living. That is the dominant need, and stamps itself upon every organism.

Man is a miscellaneous feeder and a world-wide traveler, hence all climes and conditions are his. 


\section{EACH AFTER ITS KIND}

He is at home in the arctics or the tropics, on the sea, on the land, and in the air; a fruit-eater, a grain-eater, a flesh-eater, a nut-eater, an herbeater; his generalized anatomy and his diversified mentality make the whole earth his dwelling-place, and all its thousands of treasure-houses are made available for his needs.

What diversity in unity among the hawks! Contrast these two familiar species which are nearly of a size-the marsh hawk and the hen, or red-tailed, hawk. The marsh hawk has the longer tail, and the back of the male is bluish-gray. We see it in summer beating up and down, low over the fields and meadows, its attention fixed upon the ground beneath it. At the same time we may see the henhawk soaring aloft, sweeping leisurely around in great circles, or climbing higher in easy spirals, apparently abandoning itself to the joy of its aerial freedom. The hen-hawk is a bird of leisure in contrast with its brother of the marshes. We rarely see it hunting; it is either describing its great circles against the sky, apparently in the same mood that the skater is in who cuts his circles and figures upon the ice; or else it sits perched like a statue high up on some dead branch in the edge of the forest, or on some tree by the roadside, and sees the summer hours go by. Solitude, contemplation, a sense of freedom, seem to be its chief delight, while we rarely see the marsh hawk except when it is intent 


\section{FIELD AND STUDY}

upon its game. It haunts the fields and meadows over a wide area like a spirit, up and down and around and across it goes, only a few feet above the ground, eyeing sharply every yard of surface beneath it, now and then dropping down into the grass, never swooping or striking savagely, but halting and alighting rather deliberately, evidently not in pursuit of a bird, but probably attracted by field mice. The eye follows its course with pleasure; such industry, such ease of movement, such deliberation, such a tireless quest over the summer fields - all contribute to make a picture which we look upon with interest. It is usually the female which we see on such occasions; she is larger and darker in color than the male, and apparently upon her falls the main support of the family. Said family is usually composed of three or four young in a nest upon the ground in a marsh, where it is not easy for the pedestrian to reach. The hunting habits of the hen-hawk are quite different. It subsists largely, not upon hens or poultry as its name would seem to indicate, but upon field mice and other small rodents, which it swoops down upon from a point in the air above them, where it hovers a moment on beating wing, or from the top of some old stub or dry branch in the meadow. Its nest is usually placed fifty or more feet from the ground in some large forest tree, and is made of dry twigs and branches. I have found but one marsh hawk's nest, and not more 


\section{EACH AFTER ITS KIND}

than once in twenty years do I find the nest of a hen-hawk.

Two species of our smaller hawks present about as sharp a contrast as do the two I have just described - the sparrow hawk and the pigeon hawk. It is very doubtful if the sparrow hawk ever kills sparrows, its food being largely insects, though the pigeon hawk is not above killing pigeons - at least of pursuing them with murderous intent. It is the terror of the smaller birds, capturing robins, highholes, bluebirds, thrushes, and almost any other it can get its claws upon. If you see a small bird hotly pursued by a brown hawk, the chances are that it is the song or field sparrow making desperate efforts to reach the cover of some bush or tree. On such occasions I have seen the pursued bird take refuge in a thorn-bush the branches of which had been cropped by the cattle till they were so thick and thorny that you could hardly insert your hand among them. In such cases the hawk is, of course, defeated, but he will beat about the bush spitefully in his vain attempts to dislodge his game.

The sparrow hawk is the prettiest of our hawks, and probably the most innocent. One midsummer when I was a boy on the old farm we had a sudden visitation of sparrow hawks; there must have been at least fifty about the old meadow at one time, alighting upon the fence-stakes or hovering on the wing above the grass and swooping down upon the 


\section{FIELD AND STUDY}

big, fat grasshoppers. It was a pretty sight and unusual, as I have witnessed it only once in my life.

Our birds often differ in their habits much more than in their forms and colors. We have two flycatchers singularly alike in general appearance namely, the phobe-bird and the wood pewee which differ widely in their habits of life. The phœbe is the better known because she haunts our porches and sheds and bridges, and not infrequently makes herself a nuisance from the vermin with which her nest, especially her midsummer nest, often swarms. She is an early-spring bird, and her late March or early April call, repeating over and over the name by which she is known, is a sound that every country boy delights in. The wood pewee is a little less in size, but in form and color and manners is almost the duplicate of phœbe. She is a much later arrival, and need not be looked for till the trees begin to turn over their new leaves. Then you may hear her tender, plaintive cry amid the forest branches also a repetition of her own name, but with a sylvan cadence and tenderness peculiarly its own. It differs from the phœbe's note just as the leafy solitudes of the woods differ from the strong, open light and the fence-stakes and ridge-boards where the phœbe loves to perch. It is the voice or cry of a lonely, yearning spirit, attuned to great sweetness and tenderness. The phœbe has not arrested the attention of any of our poets, but the pewee has inspired 


\section{EACH AFTER ITS KIND}

at least one fine woodsy poem. I refer to Trowbridge's "Pewee."

The nesting-habits of the two birds differ as widely as do their songs. The phœbe is an architect who works with mud and moss, using the latter in a truly artistic way, except when she is tempted, as she so often is, to desert the shelving rocks by the waterfalls, or along the brows of the wooded slopes, for the painted porches of our houses or the sawed timbers of our outbuildings, where her moss is incongruous and gives away the secret she so carefully seeks to guard. You cannot by any sleight-ofhand, or of beak, use moss on a mud nest so as to blend it with a porch or timber background. But in the niches of the mossy and lichen-covered overhanging rocks of the gorges and mountain-sides, where her forbears practiced the art of nest-building, and where she still often sets up her "procreant cradle," what in the shape of a nest can be more pleasing and exquisite than her moss-covered structure? It is entirely fit. It is Nature's own handiwork, and thoroughly in the spirit of the shelving rocks.

The pewee uses no mud and no moss. She uses lichens and other wild, woodsy things, and her nest is one of the most trim and artistic of wild-bird structures; it is as finished and symmetrical as an acorn-cup. It is cup-shaped, and sits upon a horizontal branch of beech or maple as if it were a grown 


\section{FIELD AND STUDY}

part of the tree - not one loose end or superfluous stroke about it.

Two other species of our flycatchers, the kingbird and the great crested, differ in form and coloration as much as they do in life-habits - the kingbird being rather showily clad in black, gray, and white, with a peculiar, affected, tip-wing flight, and haunting the groves and orchards, while the great crested flycatcher is rufous or copper-colored, with a tinge of saffron-yellow, haunting the woods and building its nest in a cavity in a tree, occasionally in orchards.

Nature repeats herself with variations in two of our sparrows - the song sparrow, and the vesper sparrow, or grass finch. The latter is a trifle the larger and of a lighter mottled gray-and-brown color, and has certain field habits, such as skulking or running in the grass and running along the highway in front of your team. It does not wear the little dark-brown breastpin that the song sparrow does, and it has two lateral white quills in its tail which are conspicuous when it flies. Its general color, and these white quills, suggest the skylark, and it was doubtless these features that led a male lark which once came to me from overseas, and which I liberated in a wide field near home, to pay court to the vesper and to press his suit day after day, to the obvious embarrassment of the sparrow.

The song sparrow is better known than the vesper 


\section{EACH AFTER ITS KIND}

to all country people, because it lives nearer our dwellings. It is an asset of every country garden and lawn and near-by roadside, and it occasionally spends the winter in the Hudson River Valley when you have, carelessly or thoughtfully, left a harvest of weed-seeds for it to subsist upon. It comes before the vesper in the spring, and its simple song on a bright March or April morning is one of the most welcome of all vernal sounds. In its manners it is more fussy and suspicious than the vesper, and it worries a great deal about its nest if one comes anywhere in its vicinity. It is one of the familiar, halfdomesticated birds that suggest home to us wherever we see it.

The song sparrow is remarkable above any other bird I know for its repertoire of songs. Few of our birds have more than one song, except in those cases when a flight song is added during the mating season, as with the oven-bird, the purple finch, the goldfinch, the meadowlark, and a few others. But every song sparrow has at least five distinct songs that differ from one another as much as any five lyrics by the same poet differ. The bird from its perch on the bush or tree will repeat one song over and over, usually five or six times a minute, for two or three minutes, then it will change to another strain quite different in time and measure, and repeat it for a dozen or more times; then it drops into still another and yet another and another, each 


\section{FIELD AND STUDY}

song standing out distinctly as a new combination and sequence of sparrow notes. And a still greater wonder is that no two song sparrows have the same repertoire. Each bird has his own individual songs, an endless and bewildering variety inside a general resemblance. The song sparrow you hear in Maine or Canada differs widely from the one you hear in the Hudson River Valley or on the Potomac. Even in the same neighborhood I have never yet heard two sparrows whose songs were exactly alike, whereas two robins or meadowlarks or bluebirds or wood thrushes or vesper sparrows or goldfinches or indigo-birds differ from one another in their songs as little as they do in their forms and manners, and from one end of the country to the other there is little or no variation.

During ten days by the sea one July I was greatly entertained by a song sparrow which had a favorite perch on the top of a small red cedar that stood in front of the cottage where I was staying. Four fifths of the day at least it was perched upon this little cedar platform, going through its repertoire of song, over and over. Getting its living seemed entirely a secondary matter; the primary matter was the song. I estimated that it sang over two thousand times each day that I heard it. It had probably been singing at the same rate since May or earlier, and would probably keep it up till August or later. The latter part of July and the whole of August of the same 


\section{EACH AFTER ITS KIND}

season I spent at Woodchuck Lodge in the Catskills, and across the road in front of the porch there, on the top of an old plum-tree, a song sparrow sang throughout the greater part of each summer day, as did the one by the sea, going through its repertoire of five or six songs in happy iteration. It, too, sang about three hundred times an hour, and nearly always from the same perch, and, as most assuredly was the case with the seaside bird, singing within earshot of its brooding mate. But its songs bore only the most remote general resemblance to those of its seaside brother. When, early in August, the mowingmachine laid low the grass in the meadow on the edge of which the old plum-tree stood, the singer behaved as if some calamity had befallen him, as no doubt there had. He disappeared from his favorite perch, and I heard him no more except at long intervals below the hill in another field.

The vesper sparrow has a wilder and more pleasing song than the song sparrow, but has no variety; so far as my ear can judge, it has only the one sweet, plaintive strain in which it indulges while perched upon a stone or boulder or bare knoll in a hill pasture or by a remote roadside. The charm of its song is greatly enhanced by the soft summer twilight in which it is so often uttered; it sounds the vespers of the fields. The vesper sparrow is invariably a groundbuilder, placing its nest of dry grass in the open with rarely a weed or tuft of grass to mark its site. 


\section{FIELD AND STUDY}

Hence its eggs or young often fall victims to the sharp-eyed, all-devouring crows, as they lead their clamorous broods about the summer pastures. The song sparrow more frequently selects its nestingplace in a grassy or mossy bank by the roadside or in the orchard, when it does not leave the ground to take to a low bush or tangle of vines on the lawn, as it so frequently does.

We have two other sparrows that are close akin - indeed, almost like fruit on the same tree - yet with clear-cut differences. I refer to the "chippie," or social sparrow, and the field, or, as I prefer to call it, the bush sparrow - two birds that come so near being duplicates of each other that in my boyhood I recognized only the one species, the chipping sparrow, so much at home in the orchard and around the dooryard. Few country persons, I fancy, discriminate the two species. They are practically of the same size and same manners, but differ in color. The bush sparrow is more russet, has a russet beak and feet and legs, and its general appearance harmonizes more with country surroundings. The two species differ in about the same way that the town-dweller differs from his rustic brother. But in the matter of song there is no comparison - the strain of the bush sparrow being one of the most tender and musical of all our sparrow songs, while that of the "chippie," or the hair-bird, as it is often called, is a shuffling repetition of a single unmusical 


\section{EACH AFTER ITS KIND}

note. The wild scenes and field solitudes are reflected in the bush sparrow's song, while that of the chippie is more suggestive of the sights and sounds near the haunts of men. The pure, plaintive, childlike strain of the bush sparrow - a silver scroll of tender song - heard in the prophetic solitude of the remote fields on a soft April or May morning is to me one of the most touching and pleasing bits of bird-music to be heard in the whole round year.

The swarms of small sparrows that one sees in August and September in the vineyards and along the bushy highways are made up mostly of bush sparrows. There is a little doubt but that these birds at times peck and haggle the grapes, which "Chippie" never does. The bush sparrow builds the more compact and substantial nest, using more dry grass and weedy growths, and less horsehair. It is the abundant use of hair that has given "Chippie" the name of the hair-bird.

The hair-bird appears the more strikingly dressed of the two. Its black beak and legs, the darker lines on its plumage, the well-defined, brick-red patch on its head easily separate it to the careful observer from the other species. When you have learned quickly to discriminate these two kinds of sparrows, you have made a good beginning in conquering the bird kingdom. 


\section{XII \\ THE PLEASURES OF SCIENCE}

$7 \mathrm{HE}$ greatest pleasure of life is the pleasure of 1 knowledge, the knowledge of what men have thought and done in the world - their history, their literature, their religion, their philosophy. But I am going to speak here of a particular kind of knowledge - the knowledge that has come to us through the discoveries and the deductions of modern science. This is comparatively new knowledge, but it now modifies or colors all our old conceptions of the universe. Yet a great many educated persons feel but a languid interest in it. Its impersonal and strictly objective character rather repels them. There is a widespread feeling that it kills poetry and romance, and is the enemy of religion. Of the old historical religions founded largely upon man's credulity and superstition, it surely is the enemy. It discloses to us new ground for wonder and awe in the presence of the universe, and gives to the moral law a surer foundation than can be found in the dictum of any creed or sect.

The childish conception of nature of the prescientific age we are lucky to get rid of. Do we experience any sense of loss when we find out that echo is not a nymph hiding there in the wood or in 


\section{THE PLEASURES OF SCIENCE}

the rocks, and that the rainbow is not painted upon the clouds by some mysterious hand as a sign and promise to man, and that man himself has a line of descent that connects him with the lowest forms of life?

Without laying claim to being in any strict sense a man of science, I yet take great pleasure in the world of new truths which science offers us. I graze eagerly in every one of its fields - astronomy, geology, botany, zoölogy, physics, chemistry, natural history. I do little more than graze in these fields. I select what tastes good to me. I want only the vital nourishing truths; for the I.ard, mechanical facts, the minute details, the thistles of technical knowledge I have little appetite. I join inquiry with contemplation. I loiter about the rocks, but I carry no geologist's hammer. I observe the birds, but I take no notes. I admire the flowers, but $I$ can leave them on their stems; I have no herbarium to fill. I am curious about the insects, I consider their ways, but I make no collection.

My science is as unprofessional as my religion. I tarry under the trees, muse by the streams, and commune with my own soul through the living and non-living forms that surround me. Science only seasons my observations. If I do carry home a flower, it is for its beauty, or its association; if I gather a zoölogical specimen, it is because it has more than a zoölogical interest. Exact knowledge is 


\section{FIELD AND STUDY}

good, but vital knowledge is better; details are indispensable to the specialist, but a knowledge of relations and of wholes satisfies me more.

All the facts of natural science that throw light upon the methods and the spirit of nature, are doubly welcome. I can assimilate them. I can appreciate their ideal values. I can link them up with my intellectual and emotional experiences. They make me feel more at home in the world because they so enlarge my field of interest. The ground underfoot becomes a history, the stars overhead a revelation, the play of the invisible and unsuspected forces about me and through me a new kind of gospel.

Yet I seem to approach nature through my understanding and desire for knowledge more than through any ethical or purely poetical craving. There is little of the moralist or preacher in me, but a good deal of the philosopher and investigator. I want to know the reason of things, and the relations of things, their intellectual rather than their moral values. I do not want the precise figures of the astronomer, nor the detailed proofs of the geologist, nor the formulæ of the chemist, nor the data of the zoölogist; what I want is light upon the whole of Nature - her methods, her laws, her results, her non-human ways. What I get out of botany would hardly be available for the classroom; what I get out of biology would not go into a textbook. I love 


\section{THE PLEASURES OF SCIENCE}

geology because it tells me much of the past of my own landscape; it throws light on the methods of Nature; it gives my imagination room to work; the ground underfoot becomes historic; it is like the story of one's own family written large in the valleys and on the mountains. The rocks that cumber your field are couriers from the geologic ages, the mountains were not always there, and the streams and rivers are as fugitive as the dew. The waterfalls at the heads of the gorges - what stories they tell of time and erosion! And the ledges and caverns are eloquent of ages long gone. I do not look for sermons in stones nor for books in the running brooks, I only look for a page, or a fragment of a page, of earth's history. One picks up a stone with the interest he might feel in picking up a relic on a battle-field; contending forces have fought over that ground, not often with shout and uproar, as on human battlefields, but silently and with the slowness of infinite time. Here is a flint nodule, or an angular fragment of granite rock, or a wave-worn pebble, or a rounded granite boulder, where no other granite is - what a tale of time and change each of these has to tell us if we can but read it!

I have a paper-weight on my table picked up in a Catskill trout stream. It consists of a wave-worn quartz pebble about the size of a butternut, embedded in a hard matrix of gray sand. It is a fragment from the conglomerate sandstone that caps 


\section{FIELD AND STUDY}

the higher Catskills, a chapter of world-history in miniature. It tells of the ancient sea-beaches of early Devonian times, and of the breaking-up of vast sheets of quartz rock of still earlier times. It tells of the laying-down of the sandstone strata in this vastly remote period, and of floods that carried and scattered these big quartz pebbles upon it. It tells of the lifting-up of these strata in the great Catskill plateau, and their subsequent erosion into deep valleys, and their grinding-down by the great ice-sheet. When I hold it in my hand I seem to hear the great clock of geologic time ticking off the vast periods that are but hours in the cycle of geologic change.

In Georgia I used to see large areas of the red soil under the plough, covered with fragments of quartz, suggesting bones. What a story they told of the decay of the granite rocks out of which so much of the soil of the State is made, setting free the streaks of quartz in them which is so hard that the tooth of time makes little impression upon it.

The Southern granite decays much more readily than does the New England granite, just why I cannot say. New England granite erodes very slowly, but Georgian granite seems to rot. Where these brilliant red roads cut through the hills, they lay open the earth from the ploughable soil at the surface to the decaying, crumbling, highly colored 


\section{THE PLEASURES OF SCIENCE}

strata of granite ten or fifteen feet below. The vertical sides of the roads are like painted charts showing all the gradations of the decaying rock-strata. Five or six feet below the surface one can cut the granite like cheese. From a brilliant terra-cotta it fades out as you go down, and as the rock becomes harder and harder, until the original gray of the strata begins to appear, and bars and wedges are required to remove it. Occasionally a vein of quartz is exposed which shows no sign of decay. All Northern granite that I have seen is as hard at the surface as anywhere beneath it, but Southern granite seems to possess some inherent principle of decay. Yet there are here scattered areas where the rock resists decay and huge masses crop out and seem to shake their gigantic fists in the face of Time. One such mass which I twice visited and climbed is called "Stone Mountain," not many miles east of Atlanta. It is one of the most striking granite knobs in the world. One sees it from afar rising above the surrounding country, its light-gray surface mottled with dark patches of pitch pine. Its base is six miles around, and its summit nearly a thousand feet above. Its shape suggests a huge pear, the stem end being long and low, and the blossom end high and abrupt. Standing on the high curve of this end, one cannot see the base of the mountain beneath him, and the cherry-pits which I dropped from my lunch bounded down over the brim and fell to the ground 


\section{FIELD AND STUDY}

many hundred feet below. The rock apparently does not undergo any chemical change as has the rock of the surrounding country in which it is rooted, but it disintegrates much more rapidly than Northern granite and has imparted a light-gray hue to the red lands that spread out from its base. Huge slabs weather off its surface and their degradation affords enough soil here and there to give sustenance to low growths of pitch pine. The rock as a whole must have shrunk enormously even in our geologic age, probably many times its present size; yet it remains one of the most notable outcroppings of the original granite in this country.

Why granite rock is so soft and ungranite-like in the southern countries is to me a puzzle - the result, perhaps, of some circumstance of its original cooling. In southern California, at Riverside, tourists climb or motor to a bold granite peak called Rubidoux. The sides and the summit of the mountain are strewn with huge rounded granite boulders. I chanced to overhear a tourist explaining to a friend that these detached boulders were brought there and dropped by the old ice-sheet that covered the northern part of the continent ages ago. But he was giving his friend a bit of misinformation. The old ice-sheet did not extend so far south, and these plump, smooth boulders had simply weathered out of the underlying granite, and had never left the land of their birth. They were a titanic brood 


\section{THE PLEASURES OF SCIENCE}

hatched out of the mountain by Time brooding over it for geologic ages.

Geology invests every square yard of the earth's surface with interest. I lay claim to only a fragmentary knowledge of the noble science, yet it adds to the enjoyment of every bit of new land I see, every visit I make to quarries, every glance I get of the stone tablets which the delvers and tunnelers bring out of the earth. They are pages torn from the great stone book of earthly revelations. They are often nearly blank pages to me, but they pique my curiosity and add to my interest in the great book. A little knowledge of geology goes a great way in giving me pleasure in my walks and excursions. When a new friend, curious about such things, comes to see me, I march him up to my hay barn and show him a geological treasure in one of its foundation stones; it is a complete and distinct impression, in a fragment of the light-gray Catskill formation, of the leaf of a plant or tree that flourished millions of years ago, in Devonian times, prior to the coal formation - a narrow, bladelike leaf, about a foot long, parallel-veined and deeply graven on the rock - one of the early Gymnosperms of the order of Cycads, and called Cordaites costatus. One has to supply a little imagination in order to get up an interest in such a thing, but what is life, anyhow, without imagination and void of curiosity about the earth we inhabit? 


\section{FIELD AND STUDY}

In a recent motor-car tour in the States south of me - Maryland, Virginia, West Virginia, East Tennessee, and North Carolina - my interest in the landscape was greatly heightened through my knowledge of some of the larger facts of geology. The deep, V-shaped valleys, in contradistinction to my own broad, U-shaped valleys, at once caught my eye. In many places the sides of the valleys were so steep, and the tops of the hills so smooth and round, that the farms were on their summits and the hillsides left wooded. I should not have known how to account for these features had I not known that we were beyond the limits of the great continental glacier that swept over the northern part of the country many thousands of years ago, and which so broadened and deepened our valleys and strewed the landscape with rocks and stones. In many places in West Virginia one could see where there had been local glaciers by the drift boulders and rocky fragments scattered over the fields. In going from the Catskill region to the mountainous region of Pennsylvania, one sees a change in the landscape that his knowledge of this great icesheet, and of the geological formation of the two sections, helps to clear up. The farm lands in Pennsylvania are not stony and rock-strewn as they are in parts of New York. In the Catskills the rockstrata lie in thin horizontal sheets, and are easily disrupted and torn away. In the mountains of 


\section{THE PLEASURES OF SCIENCE}

Pennsylvania, they are of different material and are folded and thrust upward; hence they presented the edges of the rock to the ice-sheet, instead of broad, flat surfaces, and were not so easily dislocated and broken up.

As a boy I had heard through relatives who had moved from the Catskills to Pennsylvania that they had to build their fences of rails, as their farms

- were quite free from rocks and stones. Now I saw the reason. The stone walls I had helped build in my youth, and the stones that had been in the way of my hoe in the cornfield, were chargeable to the old ice-sheet. But the fragments of quartz that strew some of the cotton-fields of the South have another explanation; they are what is left of the granite, the decay of which makes up the soils of those sections.

This rudimentary knowledge of geology, combined with a fair knowledge of the plants and trees, the birds and the four-footed creatures, helps greatly to make country life worth while.

I remember the look of mingled surprise and incredulity of the old farmer when I told him that his soil had once been rocks; that it was not created as he saw it there being turned up by his plough or spade; that it had been thousands, yes, millions of years in the making. He fancied that the Almighty fiat had called from nothingness the stones and rocks where they lay upon the soil, and that the soil 


\section{FIELD AND STUDY}

itself had come in the same way. From planets to peas, things are slow a-coming, and ceaseless change and transformation mark their courses.

One cannot store one's mind with any considerable part of the technical knowledge which science brings, and does not need to. An observer and lover of Nature, like myself, craves only insight into her methods; loves to trace her footsteps, as it were; to contrast her prodigality in some fields with her parsimony in others; to note her contradictions, and to cross-question her till they are cleared up. Bird and beast and tree and plant are each vital points of contact with the vast whole, and the selfsame currents flow in each.

I turn to chemistry, not for technical knowledge of substances and compounds, but for new proof of Nature's wonders and mysteries. It reveals to me a new world that ordinarily our eyes and ears do not take in - a world of activities and potencies so unlike the world of tangible bodies and mechanical forces in which we habitually live, that it never ceases to be a surprise and delight to me. Mechanical relations and rebounds we come in contact with constantly-mechanical mixtures and suspensions and siftings and transportations; but chemical reactions and transmutations are entirely of another order. In mechanics we get change of bulk, of place, of direction, of form, of color; in chemistry we get a change of substance, of quality, of nature; 


\section{THE PLEASURES OF SCIENCE}

it is as if two and two made three or five, as if one gathered grapes of thorns, and figs of thistles. What can be more marvelous than the elementary fact that two invisible and tasteless and odorless gases, oxygen and hydrogen, unite chemically in certain proportions, producing water - a body totally unlike either? Oxygen supports combustion, hydrogen burns freely, and yet water quenches fire the magic of chemical reactions truly!

Think of the terrific forces bound up in chemical compounds which fire or a blow releases! We can form no mechanical image of such things. Our springs and coils and weights may hold great forces in leash, but no more than what we put into them. The clock in running gives back or uses up the forces you put into it in winding, but the explosive compound releases energy that is of chemical origin; it is created then and there through the action of the law of chemical affinity. Nitrogen is the principal element in all the terrible explosions, and yet nitrogen is the most inert, lazy, or indifferent of the primary elements. It is reluctant to combine with any other element. Mixed with oxygen, the two form our air. Were it suddenly to unite with oxygen chemically, of which there is no danger, our atmosphere would disappear; and we should have in its place a sea of ammonia or of nitrous acids.

It is a kind of revelation when we know that the greater part of the solid earth is made of gas. A 


\section{FIELD AND STUDY}

large proportion of the earth's crust is composed of oxygen united with the mineral salts. The breath of life goes to make up the rocks and the sea and the soil we till. When two elements combine chemically, there is a mysterious interlocking of the atoms of which these elements are composed. But as the atom itself is inconceivable, - a solid particle of matter non-divisible, - one cannot picture to himself, or visualize, just what takes place. His acquaintance with a mechanical world does not help him. No more can he conceive what takes place when the mere presence of a third body in some cases causes two other bodies to unite chemically, as if certain substances in relation to certain other substances were capable of a sort of priestly function. This power is called catalysis.

A Swedish chemist has said that the third substance seemed to act by arousing the slumbering affinities of the two other substances. So far as is known, it does not part with an atom of its own substance; by its magical presence alone it hastens the chemical union of the two other bodies. This fact of catalysis is now largely made use of in the arts of manufacture.

If we had the vision of the biochemist we should see ourselves living in a world made up of two hostile camps - the micro-organisms that build up and the micro-organisms that pull down. An incessant war is waged between them, but final victory 


\section{THE PLEASURES OF SCIENCE}

rests with neither. Indeed, it is a perpetual victory and a perpetual defeat, and our well-being is in the drawn battle. If living bodies were not pulled down, there would very soon be no material to build more, or to rebuild. It is like the compositor with his type. If the compositor did not take down and redistribute his type, he could print no more books. Life and death go hand in hand. Death has its living side. What we call decay and corruption is the work of living organisms, not less than are what we call growth and health; but, we may say, of a lower and less specialized order. The germs that pull down the body of your dog are the same as those that pull down your own body, but the germs that build these up are different, at least they work to nobler ends. The pulling-down process is to return to $\mathrm{Na}$ ture the elements that came from her; the building-up process is to produce a result that contrasts strongly with the work of elemental nature. The pulling-down process goes on mechanically all about us, at all times, and it is equally active chemically. You can hardly make two stones, one piled on the other, stay piled long. Pile up your cord of stovewood in the woods as carefully as you may, and very soon it begins to incline more or less to the ground. Everything has a tilt. "Come down, come down," say the natural forces, "you oppose the equilibrium I love." Wind, rain, frost, are the great levelers. The hills and the mountains are every- 


\section{FIELD AND STUDY}

where being slowly pulled down. Where they are being lifted up by the shrinkage of the planet, their surfaces are being constantly worn down by the action of the elements. Mechanical erosion and chemical disintegration play into each other's hands. The sea is only liquid land; all the elements of the soil are in it, held in chemical solution or in mechanical suspension. Indeed, many of these elements are in the air also and are captured and used by the airplants. It is almost certain that what we call empty space is filled with the dust of extinct or of uncreated worlds.

We know our atmosphere is filled with living organisms, as well as with mineral matter. It is only with the mind's eye that we can see the world of elements and activities in which we are immersed.

The mechanical and the chemical processes that go on all about us - the tearing and wearing, the pulling and transporting, the falling and crushing, then the burnings and explosions, the transformations and dissolutions, the reactions and precipitations!

Then there is another process which we call vital which is much more mysterious, which utilizes the mechanical and chemical, but is not of them. These two forces worked together through long astronomic and geologic ages without producing living matter, then the time dawned when what we call life ap- 


\section{THE PLEASURES OF SCIENCE}

peared. When I think of these things I am compelled to see a new principle operating in non-living matter to produce the living. We see chemical affinity working to produce the various compounds - why not vital affinity working to produce living bodies?

The difficulty to the scientific mind is the idea of a new principle. Physics and chemistry are coeval with time, but life, as we are compelled to think of it, is not. So there we are up a stump. One trouble is we think too sharply of the beginning of life, think under the figure of our own beginnings, or of mechanical beginnings. Vital beginnings are brought about by slow, insensible changes, there are no sharp lines. The wheels begin to revolve, the ice in the river begins to move. Life did not begin in that way; it was beginning, or beginning to get ready to begin, for all time. The potentiality of it existed in matter from the first. As the conditions slowly ripened, life was slowly beginning, so we have to think of it as life and not-life, positive and negative, at the same time. But this is not the only case in nature where contradictions unite. When does the day begin to dawn, or the night to end? The chick breaks the shell at a definite moment of time, but when did it start on the road of chickhood? The clock begins to strike, but when did it begin to be a clock? The beginnings and endings of things are baflling. Where is the beginning of the 


\section{FIEI.D AND STUDY}

circuit of the waters from the earth to the clouds? Circles, circles, everywhere. When does a body begin to decay? At any precise moment? We unconsciously look upon the decay of dead bodies as a spontaneous process; we think of it as inevitable. But under certain conditions dead bodies do not decay, no change in them takes place; place them beyond the reach of the hosts of micro-organisms and they are safe. These two hosts, the destructive and the constructive germs, what is their relation? The destructive are in the air, the water, the soil, and in our bodies; where are the constructive? The ferments and the enzymes are in our own bodies, but where does the body get them? The cell is the architect of the living body, but what is the architect of the cell? We know its elementary constituents, but what combines them, what guides them, or inspires them to construct organs, and inspires the organs to build up bodies? There we are again with a chain that has but one end - an impossibility.

Are the micro-organisms built up or pulled down by other organisms, and so on ad infinitum?

Astronomy appeals to more persons than geology does. The ground underfoot is a commonplace affair compared with the midnight skies. The doings on our little earth, even during the lapses of geologic time, are trivial matters beside the birth of worlds 


\section{THE PLEASURES OF SCIENCE}

and systems, or their destruction, in the abyss of sidereal space. To immeasurable time is added immeasurable space. Cosmic collisions and revolutions make terrestrial upheavals and displacements like happenings in your back yard. It is not every night that one's mind opens to take in the stupendous spectacle of the starry sky. When in some felicitous moment it does so, one can but exclaim. Think of living in a world where any hour of the night the curtain may be lifted upon such a scene as that! - the Infinite baring its bosom to us, the Eternal looking directly into our eyes! And how much of this emotion, which at times overwhelms us, we owe directly to science! Our untutored minds are comparatively blind to such a spectacle. Science has given us a new vision. The book of celestial revelation has really been opened to us. What a world of new knowledge has the spectroscope opened to us! That all this heavenly host is in swift motion, going no one knows whither, suns and systems careering through space like clouds across the sky, and yet, to human eyes, during the historic period appearing like fixed points in the celestial vault - how wonderful is that!

To descend from astronomy to physics seems like a great come-down, but it is only stooping from the grandeur of orbs to the marvels of atoms, from the infinitely great to the infinitely little, from seeing the cosmic laws operating in the exterior universe above, 


\section{FIELD AND STUDY}

to seeing them repeating the same motions in the interior of matter at our feet. Physics reveals to us what we may truly call the spiritual side of matter; when we push our inquiries far enough we reach the point where gross substance becomes disembodied energy, and we find ourselves in a world as intangible as dreamland. Just as we are quite unconscious of the astronomic relations and movements of the globe upon which we live, so our ordinary lives do not reveal to us the play of forces, the attractions and repulsions that are going on in the objects about us. Whoever has had a glimpse of the Brunonian movement that is taking place in matter all about us, has got some inkling of the tumult that these attracting and repelling forces set up. 


\section{XIII}

\section{NEW GLEANINGS IN OLD FIELDS}

\section{LIVE NATURAL HISTORY}

DCENTLY, while reading Thoreau's Journal, 1 I wondered why his natural history notes, with which the Journal abounds, interested me so little. On reflection I saw that it was because he contented himself with making only a bare statement of the fact - he did not relate it to anything else or interpret its meaning. There is a great deal of bald, dry, natural history of this kind in his Journal which he never wove together into a living texture.

When he simply tells me, "I see a downy woodpecker tapping on an apple-tree and hear when I have passed his sharp, metallic note," he has not interested me in the woodpecker. He must string the bird on his thoughts in some way; he must relate him to my life or experience. The facts of natural history become interesting the moment they become facts of human history. All the ways of the wild creatures in getting on in the world interest us, because we have our ways of getting on in the world. All their economies, antagonisms, failures, devices, appeal to us for the same reason.

Thoreau's description of the battle of the ants in "Walden" is intensely interesting because it is so 


\section{FIELD AND STUDY}

human. Valor, heroism, stir us in whatever field they appear.

As I write, a little chippie comes among the vines on my porch looking for nesting-material. The old spring impulse to increase and multiply is strong upon her; she tugs at the strings that tie the vines, she scrutinizes every branch for some shred or bit that will serve her purpose. She interests me and I lend her a hand by releasing some of the strings which she couid not manage. I am familiar with her problem, as we all are. The cliff swallows daintily gathering mud at the edges of a puddle in the road, lifting their wings and standing on tip-toe as it were, to guard against soiling their plumage, is a sight I always pause to witness.

Yesterday I sat for an hour in the woods near a dead maple-stub in which a flicker was excavating her nest. At intervals the hammering would cease, and the bird, on her guard against the approach of stealthy enemies, would appear at the opening and take a long look. Finally, when she discovered me, she came out and went off in the woods, and seemed to have some conversation with her mate.

All the industries and ways and means among the animals are interesting. A chipmunk carrying nuts and seeds to her den, a red squirrel cutting off the chestnut burrs, too impatient to wait for the frost to open them on the trees, even a woodchuck carrying dry grass and stubble into his hole for a nest, 


\section{NEW GLEANINGS IN OLD FIELDS}

arrest the attention. The currents of life every where, the lampreys piling up the stones in the creek-bottom for a nest, the muskrat in the fall building his aquatic tent with mouthfuls of sedge-grass, excite our interest. In May all the seed-eating and nuteating creatures are hard put to it to obtain food. The red squirrel comes in front of my door and eats the sterile catkins of the butternut, and they evidently help tide him over this season of scarcity. One morning a gray squirrel in his quest for a breakfast invaded the tree. The red squirrel soon spied him and hustled him out of it very spitefully. The gray went undulating along the top of the stone wall, the picture of grace and ease, while the red, with tail kinked, was in hot pursuit.

To find an interest in natural history one must add something more than the fact, one must see the meaning of the fact.

I feel no especial interest in the kingbird that alights on the telephone-wire in front of me, but when he climbs high up in the air and picks some invisible insect from out the apparently empty space, and brings it back to his perch, I am interested. It was a characteristic act. The fox is interesting for his cunning, the skunk and porcupine for their stupidity. We see in the last two how the weapons of defense which Nature has so liberally bestowed upon them have left no room for the exigencies of life to develop their wits. 


\section{FIELD AND STUDY}

The novel, the extraordinary, the characteristic, the significant, always interest us. The human bore is a person who has no conception of what constitutes the interesting; he or she pours out his own private experiences upon us as if they were of the same interest to us as to him. How prone we are to think our special ailments are of universal interest, but how rarely is this the case!

One afternoon two cuckoos, flying side by side, passed my door. In the morning they passed again in the same way and going in the same direction. I became interested. I said, This means business. Following the course they took, I went straight to a clump of red-thorn trees a hundred yards distant, and there was the nest, with young more than halfgrown. They were black-billed cuckoos. The mother bird chided me in that harsh, guttural, staccato note of hers, and kept her place on a branch near the nest. One of the three young got out of the rude nest and perched on a twig, holding its head or neck nearly vertical. Its pronounced stubbly quills and peculiar attitude gave it an unbirdlike look. The cuckoos seem to time their nesting with that of the tent-caterpillars upon which they feed. As the supply of these orchard pests, and many other similar pests, had been nearly exterminated by the cold, wet May of the previous year (1917), it would have been very interesting to know how the birds made 


\section{NEW GLEANINGS IN OLD FIELDS}

up for the deficiency - what was the substitute. But I could not find out.

Nearly every cuckoo's nest I have happened to find has been on a thorn-bush. Why do they choose this tree? What special enemy are they on their guard against? Our cuckoos evidently lay their eggs at longer intervals than the other birds. In the present case one of the young was clearly several days older than its fellows. This fact, with the rude skeleton of a nest, suggests some reminiscence of the habits of the European cuckoo, a parasitical bird.

The wild life around one becomes interesting the moment one gets into the current of it and sees its characteristics and by-play. The coons that come down off the mountain into my orchard for apples on the chill November nights; the fox that prowls about near me and wakens me by his wild, vulpine squall at two o'clock in the morning; the woodchucks burrowing in my meadows and eating and tangling my clover, and showing sudden terror when they spy me peeping over the stone wall or coming with my rifle; the chipmunk leaving a mound of freshly dug earth conspicuous by the roadside, while his entrance to his den is deftly concealed under the grass or strawberry-vines a few yards away; the red squirrel spinning along the stone wall, his movements apparently controlled by the electric-like waves of energy that run along his tail and impart 


\section{FIELD AND STUDY}

to it a new curve or kink every moment, or chipping up my apples and pears for the seed, and snickering and cachinnating as if in derision when I appear upon the scene - how much there is in the lives of all these creatures that we should find keenly interesting if we knew how to get at it!

This rainy morning I saw two red squirrels make a wild dash through my garden, one in hot pursuit of the other. A woven wire fence was in the way; the fleeing one cleared one of the meshes neatly, but his pursuer, intent on his enemy, blundered and doubled up against the obstruction and was delayed a moment - how much I wanted to know what the mad racing meant, and how it resulted! The red squirrel is a perky, feather-edged creature, the hottest and most peppery rodent we have in our woods and orchards, every hair of him like a live wire, and many of his movements are to me quite unaccountable.

The search for the elements of the interesting in nature and in life, in persons and in things - well, is an interesting search.

\section{THE BARN SWALLOW}

How winsome is the swallow! How tender and pleasing all her notes! Is it boyhood that she brings back to us old men who were farm boys in our youth? We saw the swallows play out and in the wide-open barn-doors in haying-time, their steel- 


\section{NEW GLEANINGS IN OLD FIELDS}

blue backs and ruddy throats glancing in the sun, and their gentle, unctuous wing gossip falling on our ears. Their coarse nests - mud without, but feathers within - were plastered on the rafters in the peak, and when the young were out we saw them perched in a row on the ridge-board, resting from their first flights.

Now, as I sit within my barn-door outlook, the same swallows are playing before me, untouched by the many long years that have passed, giving the impression of perpetual youth; the same tender, confiding calls, the same darting, wayward flight, the same swift coursings above the shorn meadows; darlings of the ripe summer air, aerial feeders, reaping an invisible bounty above us, touching the earth in quest of a straw or a feather, or for clay for the nest, tireless of wing, and impotent of foot, as of old.

The swallow has two words, one for her friends, and one for her foes, - "Wit, wit, wit," uttered so confidingly for the friends, and "Sleet, sleet, sleet," uttered sharply for the foes.

Instead of the ridge-board of my youth, the swallow now has a new perch, the telephone and telegraph wires strung along the highway.

Shall we look upon the swallow as a songster? Virgil refers to him as such, and when he perches upon the telephone-wire in front of my barn-door and fills and refills his mouth with a succession of 


\section{FIELD AND STUDY}

those squeaking, smacking, unctuous notes, his throat swelling and throbbing, his beak opening and shutting, glancing now to the right, now to the left, as if to see if his mate is near, he looks, and we may say is, the songster that Virgil called him. The performance lacks resonance and the fluty quality of our regular song-birds; it seems to be made in the cheeks or by the softer parts of the mouth. The beak is too small and feeble to play much of a part in its production. What a waxy, adhesive sort of a sound it is! I wonder if the swallow has the organ called the syrinx common to the regular song-birds. If one may compare sound with substance I should say that the swallow's strain seems viscous and turbid rather than liquid and translucent like that of the acknowledged song-birds. It is less a musical performance for its own sake than a note of selfcongratulation, or of salutation to its fellows. The bird does not lift up his head and pour out his strain as if for the joy of singing; he delivers it as a speaker delivers his discourse, looking about him and laying the emphasis here and there in a confident and reassuring tone.

The cliff swallows and the purple martins and bank swallows are much more social and gregarious than the barn swallows. I do not remember ever to have seen more than one nest of the latter at a time in the peak of the barn, though I am told that in New England they nest in colonies. I do not know that 


\section{NEW GLEANINGS IN OLD FIELDS}

they migrate in large flocks like the other swallows. I only know that their season with us ends about the 20th of August, and that they pass the winter in South America, where I hope they have as happy a time as they do here. If anything preys upon them while they are here I do not know what it is. They could laugh at the swiftest hawk. They share the distrust of all birds toward the cat, though I have never known Puss to catch one. They will swoop down spitefully if she lingers about their haunts, and $I$ have seen her try to strike them with her paw, but have never known her to succeed.

My swallows have a pretty habit, when the day is chilly and cloudy or stormy, of collecting their brood on the little ledges or shelves above the windows on the south gable of the house and feeding them there. The young sit there in a huddled row, apparently looking off in the fields of air where their parents are coursing for insects, and when they see them returning, they break out in a happy and grateful chatter. The old weather-worn gable is for the moment the scene of a very pleasing and animated incident in swallow life.

\section{INSECTS}

One reason why all truthful and well-written books upon insects interest us more than the subject would seem to warrant is that no creature is small in print, or in a book. Print is the great equal- 


\section{FIELD AND STUDY}

izer; it magnifies the little and it minimizes the big. When Fabre focuses our attention upon a wasp. or a spider, his account engrosses our minds as completely as an account of a lion or an elephant would; the insect is singled out and separated from the thousand forms and entanglements that belittle it in field and wood; it alone occupies the page. The lion can do no more. It is precisely like putting the flea under the microscope. The wars, loves, industries, activities of Fabre's little people are described in terms and images which we use in giving an account of man and the greater beasts. The words make them big. A moment ago a minute red insect, a mere moving point, revealed itself to my eye, crawling across this sheet of paper. It was so frail and small that a bare touch of my finger, as my pocket-glass showed, crushed it. If I could give you its life history, and show its relation to other insects, it would stand out on my page as distinctly as if it had been a thousand times larger: its travels, its adventures, its birth, its death, would fill the mind's eye; the reader would not have to grope for it on my page, as my eye did when it discovered it.

There is no little and no big to nature, and there is none to the mind. We think of the whirling solar system as easily as of a whirling top. The space that separates us from the fixed stars is no more to the mind than the space that separates us from our neighbors. In like manner the atoms and the mole- 


\section{NEW GLEANINGS IN OLD FIELDS}

cules of matter, when we have once conceived of them, are as easy of apprehension as are the rocks and the mountains. The theory of their nature and activities figures as large in our minds as that of the planetary systems. The stories of many of Fabre's flies and beetles interest us as much, and are quite as significant, as the story of Jack the Giant-Killer or of Robinson Crusoe. His history of the tumblebug amuses and interests us as much as that of any of Plutarch's heroes. But see the tumblebug there in the path or by the roadside, struggling with his little black globe, and he is little more than the microscopic spider on my sheet of paper. His history must be written large, magnified by printer's type, before it comes fully within our ken or has power to move us.

Fabre's excursions afield are as entertaining and suggestive as Roosevelt's excursions into the biggame lands of Africa. With the true artist size does not count. The same is true of all the minutiæ of nature - flowers, insects, birds, fishes, frogs. We are bound to magnify them by describing them in the terms of our experience with larger bodies.

A wasp will capture its prey, paralyze it, and leave it upon the ground and then go a few yards away and dig its hole. Then it will come back, look its game over, take its measure, and apparently conclude that the hole is too small, then go back and enlarge it, sometimes making several trips of this 


\section{FIELD AND STUDY}

kind. Its attitudes and procedure would lead you to say that the wasp was thinking and calculating as a mechanic would under similar circumstances. In another case the Sphex wasp has need to paralyze the mouth-parts of the prey she is carrying, so, as she bestrides it and drags it also by its antennæ, it cannot grip her with its mandibles or impede her progress by seizing upon blades of grass by the way. Like a skillful surgeon, the wasp knows just what to do, knows in what part of the head to insert her sting to produce the desired effect.

"To know everything and to know nothing," says Fabre, "according as it acts under normal or exceptional conditions: that is the strange antithesis presented by the insect race."

But we must never credit the insect with understanding as the result of cogitation; it knows nothing; its life is a series of acts fatally linked together. The mind of the insect is the mind of Nature; it is action and not reflection. The plant does not consciously select the elements in the soil or the air that it needs, as we select; the vital chemistry in the organism does the selecting. But the moment we name what it is that does the selecting, we are caught in a trap - we want to know what prompted it to the act. We cannot find the under side of these things, because there is no under side, or upper side either, any more than there is to the earth. 


\title{
NEW GLEANINGS IN OLD FIELDS
}

\author{
IV. THE DOG
}

The most wonderful thing about the dog is not his intelligence, but his capacity for loving. We can call it by no other name. The more you love your dog, the more your dog loves you. You can win your neighbor's dog any time by loving him more than your neighbor does. He will follow you to the ends of the earth if you love him enough. He may become so attached to you that he fairly divines your thoughts, not through his own power of thought, but through his intense sympathy and the freemasonry of love.

$\mathrm{He}$ is the ideal companion because he gives you a sense of companionship without disturbing your sense of solitude. Your mind is alone, but your heart has company. He is below your horizon, but something comes up from his life that mingles with your uwn. This friend walks with you, or sits with you, and yet he does not come between you and your book, or between you and the holiday spirit you went out to woo. He is the visible embodiment of the holiday spirit; he shows you how to leave dull care behind; he goes forth with you in the spirit of eternal youth, sure that something beautiful or curious or adventurous will happen at any turn of the road. He finds no places dull, he is alert with expectancy every moment.

In him you have good-fellowship, always on tap, 


\section{FIELD AND STUDY}

as it were. Say the word, and he bounds to your side, or leads the way to the woods.

My dog enjoys a walk more than I do; his naturestudy is quite as real as mine is, though of a totally different kind; the sense of smell that plays such a part in his excursions, plays little or none in mine, and the eye and the mind, which contribute so much to my enjoyment, are almost a blank with him. He enjoys the open fire, too, and a warm, soft bed, and a good dinner. All his purely animal enjoyments are as keen or keener than mine, but has he any other?

How different his interest in cats is from mine, and in dogs, and in men! He is not interested in the landscape as a whole: I doubt very much if he sees it at all; but he is interested in what the landscape holds for him - the woodchuck-hole, or the squirrel's den, or the fox's trail. His life is entirely the life of the senses, and on this ground we meet and are boon companions.

If he has any mind-life, and ideas, if he ever looks back over the past, or forward into the future, I see no evidence of it. When there is nothing doing he sleeps; apparently he could sleep all the time, if there were nothing better going on.

\section{WOOD WAIFS}

Those little waifs from the woods - chickadees, nuthatches, downy woodpeckers, and brown creep- 


\section{NEW GLEANINGS IN OLD FIELDS}

ers - that come in winter and feed on the suet on the maple in front of my window, how much company they are to me! What thoughts and associations they bring with them! What a pleasure to have them as my guests on the old tree! The cold, naked, snow-choked woods - what can those little pilgrims get there? I think the nuthatch touches me the most closely; he is pretty to look upon, and his voice is that of a child, soft, confiding, contented, and his ways are all ways of prettiness - his sliding up and down and round the tree, his pose, with head standing out at right angles to the body, which enables him to see the approach of danger as readily as if he were perched on a horizontal limb, his pretty habit of making a vise of a crevice in the bark to hold a nut. All his notes and calls are pleasing; be is incapable of a harsh sound. His call in the spring woods when we made maple sugar in my boyhood - "yank, yank, yank" - how it comes back to me! Not a song, but a token - the spirit of the leafless maple-woods finding a voice.

And now for two or three weeks I have had another guest at the free-lunch table, the prettiest of them all, the red-breasted nuthatch from the North, and he so appreciates my bounty that he has taken up his temporary abode here in a wren's box a few yards from the lunch-table. One cold day I saw him go into the box and remain for some time. So at sundown I went and rapped on his retreat, and 


\section{FIELD AND STUDY}

out he came. He spends nearly half his time at the suet lunch. How pretty he is! and as spry as a cricket; about two thirds the size of the whitebreasted, he is quicker in his movements. He glides round the old tree like a spirit. He does not seem to have the extra joint in his neck that his larger cousin has; he does not point his bill straight out from the tree at right angles to it, but turns his head more from side to side. I call him my baby bird, he is so suggestive of babyhood. It is amusing to see him come down upon a fragment of hickory-nut when he has wedged it into the bark. Each blow is seconded by a flash of his wings, as if the tiny wings reinforced the head. One day I put out a handful of cracked hickory-nuts, and he hustled them all away as fast as he could carry them, hiding them here and there, in the vineyard, in the summer-house, on the woodpile, whether with a view to hoarding them for future use, or whether in obedience to some blind natural instinct, I know not. The white-breasted does the same thing, but I never see either of them looking up their hidden stores.

Two downy woodpeckers, male and female, but evidently not mated at this season, come many times a day. The male is a savage little despot; no other bird shall dine while he does. He bosses the female, the female bosses the big nuthatch, the nuthatch bosses the red-breast, the red-breast bosses the chickadees, the chickadees boss the brown 


\section{NEW GLEANINGS IN OLD FIELDS}

creeper and the juncos. Not one bird is hospitable to another. Each seems to look upon the suet as its special find.

The more inclement the season, the more our sympathy goes out to our little wild neighbors who face it and survive it. The tracks of the mice and the squirrels in the winter woods have an interest for one they could not possibly have in summer were they visible then. $\mathrm{O}$ frost and snow, where is your victory? $\mathrm{O}$ white and barren solitude, thou art not all-potent! How distinctly I remember where our schoolboy path through the woods crossed an old bush fence, and the fresh prints in the snow of the feet of the red and gray squirrels to whom the old fence served as a highway. Those sharp, nervous, hurried tracks and the silent, snow-choked woods, - silent except when the frost pistols snapped now and then, - how vivid the picture of it all is in my memory!

The delicate tracks of the wood mice and their tunnels up through the snow here and there beside our path - they are still unfaded in my mind, after a lapse of more than seventy years. Occasionally the stealthy track of a red fox would cross our trail both in field and wood - never hurried like that of the mice and the squirrels and the hares, but slow a watchful, listening walker in the midnight winter solitude.

Wild life in winter is like black print on a white 209 


\section{FIELD AND STUDY}

page - he who runs may read. In summer it is print on a green or brown or gray page. The little waifs from the woods that come to my door day after day in winter, so active and cheery and bravehearted, - heroic little figures that ask no favors of me or any one, yet who complacently help themselves to the proffered suet and nuts, and go their way like a merry gypsy band, - they little know that they are my benefactors as much as I am theirs.

\section{AN INTERESTING PLANT}

In our walks we note the most showy and beautiful flowers, but not always the most interesting. Who, for instance, pauses to consider that early species of everlasting, called in the botany Antennaria, that grows nearly everywhere by the roadside and about poor fields? It begins to be noticeable in May, its whitish downy appearance, its groups of slender stalks crowned with a corymb of paperlike buds, contrasting with the fresh green of surrounding grass or weeds. It is a member of a very large family, the Composito, and does not attract one by its beauty, but it is interesting because of its many curious traits and habits. For instance, it is diœcious, that is the two sexes are represented by separate plants; and what is more curious, these plants are usually found separated from each other in well-defined groups, like the men and women in 


\section{NEW GLEANINGS IN OLD FIELDS}

an old-fashioned country church. Always in groups, here a group of females, there a few yards away a group of males. The females may be known by their more slender and graceful appearance and, as the season advances, by their outstripping the males in growth. Indeed, they become real amazons in comparison with their brothers. The staminate, or male, plants grow but a few inches high; the heads are round and have a more dusky or freckled appearance than do the pistillate; and as soon as they have shed their pollen their work is done, they are of no further use, and, by the middle of May or before, their heads droop, their stalks wither, and their general collapse sets in. Then the other sex, or pistillate plants, seem to have taken a new lease of life; they wax strong, they shoot up with the growing grass and keep their heads above it; they are alert and active, they bend in the breeze, their long, tapering flower-heads take on a tinge of color, and life seems full of purpose and enjoyment with them. I have discovered, too, that they are real sun-worshipers; that they turn their faces to the east in the morning and follow the sun in his course across the sky till they all bend to the west at his going down. On the other hand, their brothers have stood stiff and stupid and unresponsive to any influence of sky or air so far as I could see, till they drooped and died.

Another curious thing is that the females seem 


\section{FIELD AND STUDY}

vastly more numerous - I should say almost ten times as abundant. You have to hunt for the males; the others you see afar off. In my usual five-minute morning walk to the post-office I pass several groups or circles of females in the grass by the roadside. I note how they grow and turn their faces sunward. I observe how alert and vigorous they are and what a purplish tinge comes over their mammæshaped flower-heads, as June approaches. I looked for the males; to the east, west, south, none could be found for hundreds of yards. On the north, about two hundred feet away, I found a small colony of meek and lonely males. I wondered by what agency fertilization would take place, by insects or by the wind. I suspected it would not take place, no insects seemed to visit the flowers, and the wind surely could not be relied upon to hit the mark so far off, and from such an unlikely corner too. But by some means the vitalizing dust seemed to have been conveyed. Early in June the plants began to shed their down, or seed-bearing pappus, still carrying their heads at the top of the grass, so that the breezes could have free access to them and sow the seeds far and wide.

As the seeds are sown broadcast by the wind, I was at first puzzled to know how the two sexes were kept separate, and always in little communities, till I perceived what I might have read in the botany, that the plant is perennial and spreads by 


\section{NEW GLEANINGS IN OLD FIELDS}

offsets and runners like the strawberry. This would, of course, keep the two kinds in groups by themselves.

\section{NATURE NEAR HOME}

After long experience I am convinced that the best place to study nature is at one's own home, - on the farm, in the mountains, on the plains, by the sea, - no matter where that may be. One has it all about him then. The seasons bring to his door the great revolving cycle of wild life, floral and faunal, and he need miss no part of the show.

At home one should see and hear with more fondness and sympathy. Nature should touch him a little more closely there than anywhere else. He is better attuned to it than to strange scenes. The birds about his own door are his birds, the flowers in his own fields and wood are his, the rainbow springs its magic arch across his valley, even the everlasting stars to which one lifts his eye, night after night, and year after year, from his own doorstep, have something private and personal about them. The clouds and the sunsets one sees in strange lands move one the more they are like the clouds and sunsets one has become familiar with at home. The wild creatures about you become known to you as they cannot be known to a passer-by. The traveler sees little of Nature that is revealed to the homestayer. You will find she has made her home where 


\section{FIELD AND STUDY}

you have made yours, and intimacy with her there becomes easy. Familiarity with things about one should not dull the edge of curiosity or interest. The walk you take to-day through the fields and woods, or along the river-bank, is the walk you should take to-morrow, and next day, and next. What you miss once, you will hit upon next time. The happenings are at intervals and are irregular. The play of Nature has no fixed programme. If she is not at home to-day, or is in a non-committal mood, call to-morrow, or next week. It is only when the wild creatures are at home, where their nests or dens are made, that their characteristics come out.

If you would study the winter birds, for instance, you need not go to the winter woods to do so; you can bring them to your own door. A piece of suet on a tree in front of your window will bring chickadees, nuthatches, downy woodpeckers, brown creepers, and often juncos. And what interest you will take in these little waifs from the winter woods that daily or hourly seek the bounty you prepare for them! It is not till they have visited you for weeks that you begin to appreciate the bit of warmth and life they have added to your winter outlook. The old tree-trunk then wears a more friendly aspect. The great inhospitable out-of-doors is relenting a little; the cold and the snow have found their match, and it warms your heart to think that you can help these brave little feathered people to win 


\section{NEW GLEANINGS IN OLD FIELDS}

the fight. Not a bit daunted are they at the fearful odds against them; the woods and groves seem as barren as deserts, the earth is piled with snow, the trees snap with the cold - no stores, no warmth anywhere, yet here are

\section{"these atoms in full breath \\ Hurling defiance at vast death."}

They are as cheery and active as if on a summer holiday.

The birds are sure to find the tidbit you put out for them on the tree in front of your window, because, sooner or later, at this season, they visit every tree. The picking is very poor and they work their territory over and over thoroughly. No tree in field or grove or orchard escapes them. The wonder is that in such a desert as the trees appear to be in winter, in both wood and field, these little adventurers can subsist at all. They reap a, to us, invisible harvest, but the rough dry bark of the trees is not such a barren waste as it seems. The amount of animal food in the shape of minute insects, eggs, and larvæ tucked away in cracks and crevices must be considerable, and, by dint of incessant peeping and prying into every seam and break in the bark, they get fuel enough to keep their delicate machinery going.

The brown creeper, with his long, slender, decurved bill, secures what the chickadee, with his 


\section{FIELD AND STUDY}

short, straight bill, fails to get. The creeper works the trunk of the tree from the ground up in straight or in spiral lines, disappearing quickly round the trunk if he scents danger. $\mathrm{He}$ is more assimilatively colored than any of his winter congeners, being like a bit of animated bark itself in form and color, hence his range and movements are more limited and rigid than those of the woodpeckers and chickadees. The creeper is emphatically a tree-trunk bird. His enemies are shrikes and hawks, and the quickness with which he will dart around the trunk or flash away to another trunk shows what the struggle for life has taught his race.

The range of the nuthatch is greater than that of the creeper, in that he takes in more of the branches of the tree. He is quite conspicuously colored in his suit of black, light gray, blue, and white, and his power of movement is correspondingly varied. His bill is straight and heavier, and has an upward slant with the angle of the face that must serve him some useful purpose. He navigates the tree-trunks up and down and around, always keeping an eye on every source of danger in the air about him. I have never seen a nuthatch molested or threatened by any bird of prey, but his habitual attitude of watchfulness while exploring the tree-trunks, with head bent back and beak pointing out at right angles, shows clearly what the experience of his race has taught him. Danger evidently lurks in that direction, and black and 


\section{NEW GLEANINGS IN OLD FIELDS}

white and blue are revealing colors in the neutral woods. But, however much the nuthatch may be handicapped by its coloration, it far outstrips the creeper in range and numbers. Its varied diet of nuts and insects no doubt gives it a more vigorous constitution, and makes it more adaptive. It is the vehicle of more natural life and energy.

How winter emphasizes the movements of wild life! The snow and the cold are the white paper upon which the print is revealed. A track of a mouse, a bird, a squirrel, or a fox shows us at a glance how the warm pulse of life defies the embargo of winter. From cracks and rents in the frigid zone which creep down upon us at this season there issue tiny jets of warm life which play about here and there as if in the heyday of summer. The woods snap and explode with the frost, the ground is choked with snow, no sign of food is there for bird or beast, and yet here are these tiny bundles of cheer and contentment in feathers - the chickadees, the nuthatches, and their fellows. 


\section{Part II STUDY NOTES}





\section{Part II: Study Notes \\ I}

\section{LITERATURE}

THE natural history of the fields is usually as

1 welcome to the poet as to the field naturalist, even though he does not put it into his song. It was certainly welcome to Emerson, and his poems abound in allusions to the life of the fields, both floral and faunal. But the poet is not out in quest of natural-history facts; he is in quest of any facts he can make into poetry. "A little more than a little" of these things would burden his lyric. He is intent upon the play of his own fancy and feelings over the larger and more general aspects of the landscape. Emerson went to the woods, not to bring home bird or botany lore, but to fetch the word of the wood-god to men. When he brought the asters back with him, each came "laden with a thought," but when he brought back the poems of the "Humble-Bee" and "The Titmouse," he brought back, in each case, a bit of sound natural history, animated and expanded with genuine poetic emotion. His "May-Day" is rife with close observation of nature at this season, but it is not burdened with the details.

The poet uses the facts of natural history and of 


\section{FIELD AND STUDY}

science generally in a large and free way, not to convey information, but to stimulate the poetic sense. His treatment is synthetic and not analytic. Every cloud that floats above him "writes a letter in his book," but these things are not ends in themselves, they are but the colors upon his palette. The picture he paints is not in nature, but in his own soul. He uses objects in nature to figure forth a mood of the soul, not for the flower's or the bird's sake, but to fathom the sense of solitude in the spirit. Such poems express a sympathy with nature that was quite alien to the ancient mind.

\section{$\S$}

Shall we ever again have a group of poets who can deal with nature in the large, virile way in which some of our older poets did, giving us the same sense of reality, stirring the same universal emotions of our common humanity, portraying what we all see and feel but cannot all express, as Bryant did in his "Waterfowl," and several other poems, as Emerson did in his "Humble-Bee" and "Titmouse," as Burns did with his "Mouse," as Wordsworth did in the "Cuckoo" and the "Daffodils" and in scores of poems, as Whitman did in numerous passages in his large, flowing lines, as Trowbridge did in his "Pewee," and "Mid-Summer," and as Celia Thaxter did in her "Sandpiper"?

I recall but one of our current poets who has touched a nature theme in the old, felicitous, and, 


\section{LITERATURE}

at the same time, truthful way, and that is Robert Loveman in his immortal "Rain Song."

The school of younger poets, with their free verse, turn perpetually to nature themes, but the large, free handling of them is not their gift. Neither is it the gift of the poets who adhere to the old conventional form of verse. They are pretty and refined, they are often subtle and fluent, but there is not a particle of "original sin" in any of them - nothing that gives flavor and reality; it has all been bleached out; they are a by-product of a bookish and artificial age; they are skilled craftsmen, but not poets; they are what is left for the making of poets after the first-hand grit and energy of the race has been drawn off by the demands of a great practical industrial age. These pale, thin, anæmic versifiers are the left-overs.

\section{$\S$}

The secret of good writing is not in the choice of words; it is in the use of words, their combinations, their contrasts, their harmony or opposition, their order of succession, the spirit that animates them. A writer upon Nature may expatiate on her beauties, but can he show us her beauties in simple language? Can he in plain words make us feel the poetry in the morning, or in the twilight? Just to name objects in nature, like the dew, the rain, the snow, a summer morning, a clover-ficld, the midnight skies, the clouds, the brook, is enough, through 


\section{FIELD AND STUDY}

the power of association, to fill the mind with pleasing emotions.

A writer may use pure English and yet his production be flat and insipid. No matter what words a fourth- or fifth-rate poet uses, his verse will be fourth- or fifth-rate. Take any great piece of prose and break it up into its word elements, and see if you can find the secret of its power or beauty. The words "beauty" and "power" may not be in it, and yet it may have both these qualities. The difference between a quartz pebble and a precious stone is not one of elements, but one of different arrangement of the same elements. Both the diamond and a lump of charcoal are made up of carbon molecules, but behold the difference!

"In good writing words become one with things," says Emerson. They give a sense of reality, the mind feels them as tangible things. Of course, words that stand for specific, concrete things come home to us in a way that general and abstract words do not. Take this quatrain of Emerson's:-

"Cast the bantling on the rocks, Suckle him with the she-wolf's teat, Wintered with the hawk and fox,

Power and speed be hands and feet."

How vivid and concrete the language! Certainly the words are one with things. 


\section{LITERATURE}

\section{$\S$}

Mr. Perry, in his "Life of Whitman," does not bring out Whitman's main characteristics very clearly - the fact that he stood so entirely upon ground of his own, was, in fact, a new type of man appearing in literature, and that he proved and justified himself upon those new grounds.

Mr. Perry has to chip away a good deal of Whitman to make him conform to the accepted academic models, and the process is like shearing Samson of his locks - his strength and significance are gone. If one fails to see that here is the democratic spirit assuming almost colossal proportions, taking possession of the world in its own right, gay, proud, nonchalant, but loving and all-inclusive, reverent toward the past, receptive toward the present, confident toward the future, taking science at its word that the celestial laws are operative here underfoot as well as up there in the sky, taking religion at its word that the greatest thing in the world is love and that man is divine inside and out, writing his poems from the inspiration of these ideas, and bringing the democratic standard, the standard of the fundamental equality of all men, to bear upon all things, and thereby making in a sense a new scale of human values - unless, I say, one sees this in Whitman, one misses the main thing. It seems to me almost an impertinence to compare him to Rousseau, or Wordsworth, or our own Whittier, 


\section{FIELD AND STUDY}

because his spirit and aim are so foreign to theirs. The spirit of these men was not inclusive but exclusive; not one of them could say:-

" $\mathrm{My}$ spirit has passed in compassion and determination around the whole earth;

I have looked for equals and lovers and found them ready for me in all lands."

Whittier was a democratic poet within certain narrow limits, as are most of our poets, but as an enclosure of his country, and of the modern world, he is a child compared with Whitman. The poets just named are poets of the select, the refined, the exceptional. Whitman is the poet of the All. But all is not beautiful or poetic. Granted. Yet Whitman included it just the same, and, what is more, he gives you the impression of being adequate to include it. It does not stagger him or swamp him; his spirit dominates it. Had he not loaded his work with material which in itself does not awaken the poetic thrill, he could not have given this impression of all-inclusiveness and of cosmic power.

Whitman's catalogues, and his affliations with what is considered unclean, would have destroyed Whittier, because Whittier's spirit was not adequate to bear this burden. Nothing but Whitman's tremendous egoism, and the power to keep his own spirit always to the front, enabled him to stand up under the load he assumed.

This want of selection in Whitman, which Mr. 


\section{LITERATURE}

Perry, like the other critics, makes much of, was a vital part of Whitman's entire scheme. The question is not, Does he transmute his common material into the gold of poetry? but, Has he enough gold in his vaults to redeem it? Is he master of it? What would clog a brook is lost in a river. Had Whitman attempted to prettify these things, to dress them up in the habiliments of rhyme and poetic finery, that would have put another face on his enterprise.

The most precious thing any imaginative work can give us is the impression of a large, loving, and powerful personality. I care not what the medium is if it gives us this impression. Is not greatness of soul above all else? Plenty of poets give us the impression of the refined, the pretty, the gentle, the devout, but how many give us the impression of the great, the powerful, the godlike? Of the cosmic and the all-inclusive, Whitman alone among poets gives us the impression.

Were the final impression which he makes that of the uncouth, the coarse, the half-cultured, or the merely big, how long, think you, could he hold the attention of thoughtful minds? Not long, surely. This was the first impression he made upon John Addington Symonds. "But in course of a short time," he says, "Whitman delivered my soul of these debilities"; that is, brought him a stimulus and a message which are never the gift of the coarse and the uncouth. 


\section{FIELD AND STUDY}

The purely academic mind always gets the impression of uncouthness from Whitman, and, if there are not native and original gifts back of the academic veneer, as there were in Symonds, gets no farther.

You may refuse to call Whitman's work poetry, but it is not prose. His attitude toward his subject and toward his reader is not that of the prose-writer. It' is more intimate and personal, more symbolical and representative. It is that of the bard and prophet, if not of the poet. The prose-writer is bent on elucidation, argumentation, description, or the conveyance of knowledge. Whitman's aim is none of these. The personality of the man is immanent in all Whitman's best wrrk; he gives himself. His spirit is creative, primary, elemental. He identifies himself with men and things, and they speak through him instead of his standing apart from them and merely portraying them or contemplating them or singing of them. The poets quicken one's pulse by their fine descriptions and imaginary touches. Whitman speaks in the spirit of Nature as a whole; not beauty merely is his aim, but love, power.

$\S$

I return to Wordsworth again and again, year after year. His privacies with Nature, his communing with his own soul, through her shows and objects, appeal to me. This modern devout feeling toward Nature, as distinguished from the ancient 


\section{LITERATURE}

pagan feeling of simple fear and wonder, we are all sharers of. It is the aftermath of the human mind that follows the decay of the old religious forms and creeds. Wordsworth's natural religion was the reality with him; his Church of England religion was only a form.

I return to Whitman again and again, year after year, not for his privacies with Nature, but for the sweep of his mind and the power of his personality. His tremendous humanism and large style always refresh me. He makes me ashamed of our partialities and refinements and false modesties. His frankness and directness are as appealing as his unconventionalities. His candor equals his charity, his democracy matches his patriotism. He does not distil the essence of wild Nature for me as Wordsworth does Nature transmuted into a kind of intellectual sentiment; he distils nothing, he confronts me with the immeasurable universe and makes me feel how the ground I walk upon is a part of the solar system. It is not Nature perfumed with literature that he gives me, but something much nearer the breath of Nature as she appears on the shore, the plains, the mountain-tops.

There is no direct savor of science in this passage:-

"I open my scuttle at night and see the far-sprinkled systems, And all I see multiplied as high as I can cipher edge but the rim of the farther systems. 


\section{FIELD AND STUDY}

"Wider and wider they spread, expanding, always expanding, Outward and outward and forever outward.

"My sun has his sun and round him obediently wheels, He joins with his partners a group of superior circuit, And greater sets follow, making specks of the greatest inside them."

That is all good astronomy, and it is all good poetry.

Whitman's personality is always the dominant fact. He assimilates and transmutes science as easily as anything else. His tremendous egoism cannot be obscured or thwarted. It enables him to identify himself with all objects and persons without suffering the least embarrassment or degradation. While other poets aim to write beautiful poems by selection and elaboration, Whitman aims to write poems of power by including all and elaborating nothing. While other poets seize upon some special phase of Nature, and make much of that, Whitman gives the spirit of Nature in her totality. Many persons who are moved by a flower, a bird, a sunset, or a shell on the beach, are unmoved by the midnight skies and the larger elemental displays. Vastness, power, universality, are Whitman's characteristics as a poet. While touching the highest point of modern knowledge and humanitarianism, on the one hand, he reaches to the antique simplicity and religious fervor on the other. He is prophetic and creative, while he is Darwinian and democratic. His 


\section{LITERATURE}

subject-matter is the universe. He says his book is a poem of himself; it is himself in relation to the whole of life and of Nature. He is no more a gatherer of flowers or of shells upon the beach than a rhapsodist of the ocean or a worshiper of the stars; no more a lover of men than a disciple of the gods; no more a countryman than a "lover of populous pavements"; no more a lover of solitude than a lover of the mart. He is always large, he always gives one a sense of mass and magnitude, of movement and power.

As an artist he does not loiter, he does not elaborate, he does not finish specimens; he showers them, as he says, by exhaustless laws, continuously, as Nature does. He is always fluid and flowing, always central, never baldly intellectual or reflective or studiously subtle. He does not savor of books or of schools. He is not a product of culture and of generations of speaking and writing men, as Emerson is; hence he has little of the peculiar Emersonian aroma of scholars and scholarly traditions, or of the distilled and concentrated essence of the wild and the secluded, which in certain moods is so welcome to us. His "Leaves" do not lure us to the woods or to the brookside, but rather to the seashore or to the mountain-top. He does not make you conscious of his craft; he fills you with the feeling of himself.

In the modern nature pocts, such as Wordsworth 


\section{FIELD AND STUDY}

and Emerson, we get the thrill of the idyllic, or the charm of the pastoral. In Whitman we get the lift and sweep of the epic, and, at times, the stir of the dramatic. We may not like him, - not everybody can endure a plunge in the surf, - but we should recognize his power, and the genuineness of his inspiration, and that our dislike of him comes more from our indoor and bookish habits, our overrefinements, our artificial standards, our anæmic blood, than from any want of the truly poetic in his "Leaves."

His attitude toward his subject-matter is always that of the creative artist, never that of the prosewriter, or the preacher, or the speculative philosopher. He gives nothing as duties, as he himself says, but as living impulses; he gives nothing as finished poetry, but as the soul and suggestion of poetry. His book is not a temple of art, builded as the great architects of verse, from Virgil to Tennyson, built it, but is the work of the creative and assimilative artistic spirit where life is unloosed and we breathe the air of primal and universal nature. To describe him as merely rude and hirsute and untaught is to miss the mark entirely; he is elemental and primitive, but he is orbic and inclusive. Neither do the epithets "robust," " athletic," "masculine," and the like fitly describe him. He is more and better than these; he is tender, yearning, motherly. 


\section{LITERATURE}

It has been said that "Milton is the most literary man in literature." I should say the greatest purely literary man in English literature. Virgil matches him in Latin literature. Who matches him in French? By a literary man, in the sense here referred to, I suppose we mean one whose primary interests are in literature rather than in men and things - the product of books, of the schools. Shakespeare was not literary, nor Scott, nor Wordsworth, nor Carlyle, nor Burns, nor Emerson. Emerson's interest in poetry was great, was almost supreme, and yet he was not literary in the sense that Arnold was or that Lowell was. He again was a poet and prophet combined, or a critic and a seer combined; a preacher who hated preaching and the church, a poet thrilled by the grandeur of the moral law, an essayist whose central theme was God and Nature, a critic who saw literary values through his religious sense, a philosopher who thought in tropes and symbols, a naturalist who translated his natural history into the language of the spirit.

$\S$

How prone we are to speak of style as something apart from the man, and to compare it to a garment that can be put off and on! whereas style is a quality of mind, and either a man has it or he has it not. It is as inseparable from the man himself as his temperament or complexion. A writer has style if 


\section{FIELD AND STUDY}

his page is vital and gives the impression of an original and attractive personality. Again we speak of the style and the thought as being separable, but they are one as the line of a pearl is one with the substance. There is a world of good writing which yet differs from literature as a tree differs from a pile of lumber. Lucidity as a requisite of style certainly stands first, and next that which is inseparable from it, simplicity. In my own case I try to get language out of the way as far as possible, and to put my mind directly to that of my reader. Hence, when I have been told that my page does not seem like writing, that it offers no resistance, and so on, I feel highly complimented. I would have it fit the mind as water fits the hand. Deliver me from language as such, from fine phrases; in short, from conscious style. The author must not know that he is writing, but seem only to be speaking. The moment he knows he is writing, his words begin to rattle and sound hollow. I do not want to hear or see or feel the machinery. I want the perfect product. I want the writer to be so intent upon what he is saying, so single of purpose, and so honest with his reader, that he takes no thought of his style as such; he takes thought only of how to convey his meaning in the clearest, freshest, most direct and vivid manner. $\mathrm{O}$ to be natural, to have the quality of freshness and inevitableness, of the unlabored, the spontaneous! To be brisk and not flippant, to be 


\section{LITERATURE}

original and not strained, to be smooth and not polished, to be suggestive and not obscure and indefinite, to be bright and not brilliant, to have wit without the sting, to have humor without the guffaw, to have learning without pedantry, to have joy without hilarity, — "sober on a fund of joy," as Emerson says, - to be serious and not heavy, to teach and not moralize, to be lucid and not superficial, to be eloquent and not rhetorical, to have common sense and not be commonplace - this is my prayer.

\section{$\S$}

Whoever can bring to scientific subjects a free play of mind and find room in them for feeling and imagination, can make literature of them. Astronomy, geology, botany, chemistry, physies, all lend themselves to literary treatment to the born literary mind. Their exact facts may be made flexible and grouped in a picturesque manner, and invested with the atmosphere of poetry and romance.

$\S$

I think we all in a measure share the feelings of those who would rather read an account of an event or a description of an object by a great writer than to see the object or be present at the erent itself. To persons with the literary and artistic sense highly developed, the reality is generally less pleasing than a picture of the reality.

It is said that all martyrdom looks mean in the 
act. I had rather read "Macbeth" than to have been present at the scenes upon which it is founded.

The difference between a photograph and a painting is an important difference, not so much a difference of fact as a difference of spirit and atmosphere. The artist does something to his facts, the photographer does not. Facts that have passed through the personality of an artist meet with a change; a touch of the ideal has been added; there is a novelty, a beguiling strangeness; the spirit of romance has breathed upon it and, without blurring its realism, has imparted a charm which the reality did not have. The literary artist goes to nature or to human life for his material, but unless he does something to that material, something analogous to that which the bee does to the nectar which she gathers from the flowers before she stores it as honey, it will be unworthy the name of literature. It may have value as science, or as statistics, but not as literature. The bee concentrates the sweet water which she gathers from the flowers and adds a minute drop from her own body in the shape of formic acid before she achieves honey. The writer who goes to the field or the street or the mart or the trenches for his subject-matter will not achieve literature by merely a faithful transcript of what he sees and feels - his matter must be touched to the finer issues of the imagination. Much of that which passes for realism in current literature is merely the 


\section{LITERATURE}

crude material of literature; it has not met with the change to which I refer. Fidelity to the fact is not enough; fidelity to the ideal is also necessary.

When the sap of the tree rises from the roots to the leaves, it is crude sap; when it has been touched by the sun through the leaves and flows downward to build up the tree and its fruit, it is another matter. When our experiences and observations have been touched and sublimated by emotional and ideal nature, they become another matter, too. Who would not read of a street brawl, or a scene in a gambler's den by a great imaginative writer, rather than witness the reality? Who would not rather meet Falstaff or Hamlet or Lear in the pages of Shakespeare than in the street or the house?

I confess I cannot read the stories of our new writers without being disturbed by their bald, hard realism. Their tales of frontier life are almost as repulsive as the reality. With all the wit and the accurate character-drawing, their impact upon my mind is not that of literature, but of naked reality. A bar-room brawl is a bar-room brawl and nothing more, repulsive in the beholding and distasteful in the reading, without a touch of that light that never was on sea or land - the touch which past events have in our memories. I do not hesitate to say boldly that there is no art or literature until the matter has been breathed upon by the great god of romance. If $I$ confess I had rather have a 


\section{FIELD AND STUDY}

photograph of my friend than a painting, it is that the photograph brings him nearer. The painter will disguise him a little. Would not one rather have a photograph of any of the great characters of the past, or of his own great-great-grandfather, than a picture of him by any portrait-painter? One would like to know exactly how he looked, the naked reality. Yet a painting of my native hills pleases me more than a photograph, because I suppose the question of color and atmosphere plays such a part, while in the face of your friend expression plays the main part and color a very minor one. The camera has no imagination, no sentiment, and no memory, and its literal truth is not art; but for that very reason, it gives us the nude reality when we wish it most. Our own memories and feelings do the rest.

Here we come upon ticklish ground and must choose our words. I have no sympathy with those readers who, for instance, had rather read Audubon's account of a bird than see and hear the bird itself, or read a great historian's description of a battle than to have witnessed it. The great and the momentous things in life one wants to see; in the absence of that experience, then an account of them by a great writer. In all cases the written description will give one a kind of pleasure that the reality could not give, an æsthetic pleasure, but the reality drives deeper and is unforgettable. You for- 


\section{LITERATURE}

get a description of Niagara, but you do not forget the vision of it. As we cannot always see the reality, but must read about it in innumerable books, we want the reading to spare us the triteness and disagreeableness that we are bound to get more or less of from the reality.

I am not trying to discount the real thing; we go around the world to see real things; I am only trying to say that when we aim to make literature or art out of them, we must invest them with a feeling, an atmosphere, that the literal fact cannot give; we must work some magic upon the facts.

You may put into your picture what cannot be found in nature, but I must not be able to put my finger on it. It must be your own spirit, your own atmosphere. It must be in the tone, in the quality - something that will make me want to go to that place and live there always. Your elms must be elms and your maples, maples, and your rocks, rocks, but there must be a light upon them that never was upon sea or land.

Who could paint for me the old homestead with the charm it has in my memory, not changing a single feature, but touching every feature with the charm and pathos with which it haunts me?

Pass a landscape through the soul of a great artist and it is in a measure transfigured, while it remains the same.

Wordsworth's "Daffodils" gives us more than 239 


\section{FIELD AND STUDY}

the daffodils of the botanist; Emerson's "HumbleBee" gives us more than we can get from any work on entomology; Burns's "Mouse" is a real mouse, but not the one you catch in a trap; and Shakespeare's violets - where do they grow save in the magic page of Shakespeare? Art always rises above fact.

I am insisting upon these things as if I thought there were those who would dispute them, but probably there are not. Realists and idealists must agree when they understand one another.

$\S$

Young men of literary ambition often ask me what they shall do to become good writers. I usually answer that there is not much hope for them or they would not ask that question. If they were born to write, they will not need much guidance. If they were not, who can really help them? The old advice, "Look into your heart and write," puts the whole matter in a nutshell, but if the heart has no interior, if it is not in some sense a mirror of the universe, what is the use of looking?

One may say straight seeing, clear thinking, and keen feeling are among the prime requisites for good writing, but telling the blind to see and the dull to feel and the halt to be nimble is not very practical advice. 


\section{II \\ RELIGION}

T $\mathrm{Y}$ readers sometimes write me and complain D that there is too much Nature in my books and not enough God, which seems to me like complaining that there is too much about the daylight and not enough about the sun. What, then, is Nature? Whence its source? Why are we Naturelovers?

Of course the above criticism springs from the old conception which has been so long drilled into us, namely, that there are two - Nature and God - and that they are often at strife as Tennyson hints when he asks, "Are God and Nature then at strife?"

I look upon Nature not merely as the garment of God, but as his living integument. With a manlike God, the maker and ruler of the universe, and existing apart from it, I can do nothing.

When I write about Nature and make much of her beauties and wonders, I am writing about God. The Nature-lover is the God-lover. I am chary about using the term "God" because of its theological and other disturbing associations. There is something too austere and forbidding, and even terrible, in the conception it calls up. But call it 


\section{FIELD AND STUDY}

Nature and it is brought immeasurably near. I see it, touch it, hear it, smell it. I see the flowers, the birds, and all engaging aspects of field and wood and sky. I am a part of it. I see my absolute dependence upon it, and that denying it or slighting it, or turning my back upon it, were like denying or slighting gravity.

$\S$

Where are the tracks we made in the snow last winter? How real they seemed! how much they expressed! They told which way we were going, whether we were hurrying or sauntering, what we had on our feet, and they might easily tell if we bore a burden, or if we were drunk or sober, if we were man, or woman, or child. They were real. The snow still exists in the form of water or vapor, and the feet that imprinted themselves upon the snow may still exist, but the tracks that meant so much - where are they? The track was simply a record, like any other print or writing, and does not exist apart from the material substance that gave and took the impression. Are we ourselves anything more than the tracks of the Eternal in the dust of earth?

$\S$

The serious, reverent, and truth-loving mind will never be without religion, because these traits are the fountain-head of all religious emotion. Add the logical faculty, and the gift of imagination, and such 


\section{RELIGION}

a mind will go to nature for its religion rather than to creeds and traditions. It must have something tangible, and it must have something that stimulates its idealism. Science may afford its foundation, but not its finish. Its science must be supplemented by its philosophy. Minds without reverence and ideality stop with science and usually end in materialism, but minds trained in the scientific method, and with the gift of ideality, like Tyndall, Huxley, and others, can never rest content in what is usually called materialism.

$\S$

That one of our well-known college professors should recently have named his volume treating of the physical aspects of the earth and our relations to it "The Holy Earth" shows what a change has come over the lay mind in regard to universal nature in comparatively recent times. The lay mind is rapidly becoming more truly devout than the clerical mind - more inclined to act upon the literal truth of the assertion that the earth is divine, and that God is everywhere. The clergy have barely yet discovered that the earth is a celestial body as are all the rest of the hosts of heaven, and that the morning star is no more divine than the morning earth.

$\S$

The man of science is forced to account for man upon natural grounds. He knows no other. In searching the heavens and the earth through, he 


\section{FIELD AND STUDY}

can find no other. The whole procession proceeds according to natural law. No hand is reached forth out of the void arbitrarily to change anything, or to introduce anything, or to interfere with the regular order. Everything has its antecedent, or refers to something gone before. Nothing begins de novo. We appear and play our part in a series of events which we fancy must have had a beginning and which will have an ending, but we deceive ourselves; we measure the infinite by the finite; there is no beginning or ending to the universe, there is only continuance with incessant change. The earth did not begin as the world we know; it did not begin as we find it in any past geologic age, or astronomic age. It probably came out of the sun, and it came out of a vast cyclone of star dust; and it came out of what? Be assured out of some preceding condition of eternal matter.

\section{$\S$}

The change of man's attitude toward nature is one of the most, if not the most, remarkable changes in his mental and spiritual story in modern times. It amounts to a revolution. What he once feared and fled from, he now loves and studies and endows with a high degree of religious and spiritual value.

The fields, the woods, the waters, the starry night, have an attraction and a meaning to the modern mind that the mind of the pre-scientific ages had no conception of. 


\section{RELIGION}

"The meanest flower that blows" can bring to Wordsworth "thoughts that do often lie too deep for tears." How impossible such a poet as he in an earlier time! With all his outward adherence to a religion of creeds and rituals, he was at heart the poet of Nature. His attitude toward her was a religious attitude, as has been more or less the attitude of the leading poets since his day. "The primal sympathy" which he celebrates - the sympathy with birds, flowers, trees, rocks, winds, waves we are all more and more conscious of, partly because he gave that sympathy utterance in such inspired lines, and partly because science has given us a more intelligent conception of the mysteries and the glories that surround us. Many of us can now say with him:-

\section{"And I have felt}

A presence that disturbs me with the joy

Of elevated thoughts; a sense sublime

Of something far more deeply interfused, Whose dwelling is the light of setting suns, And the round ocean and the living air, And the blue sky, and in the mind of man: A motion and a spirit, that impels All thinking things, all objects of all thought, And rolls through all things. Therefore am I still A lover of the meadows and the woods, And mountains; and of all that we behold From this green earth; of all the mighty world Of eye, and ear, - both what they half create, And what perceive; well pleased to recognize In nature and the language of the sense, 


\section{FIELD AND STUDY}

The anchor of my purest thoughts, the nurse,

The guide, the guardian of my heart, and soul Of all my moral being."

That creative eye and ear in the presence of Nature is what mainly distinguishes the modern attitude from the ancient. Sympathy is always creative. "Thanks to the human heart by which we live."

$\S$

Emerson refers to a Swedenborgian neighbor of his who was a philosopher up to a certain point, and then accepted the village church as a part of the sky; he says the day is not far distant when men will cease thus to patch the ecliptic of the universe with a small bit of tin. Is not this the mistake all the good church people make? Nature is so much bigger than their creed, and so much more real, that it is like confounding a shingle roof with the firmament. The gulf between the sky and the church is no greater than the gulf between the orthodox religion and our natural knowledge.

$\S$

That Christ came out of the earth, that the Hebrew prophets, that Paul, that all the saints and poets and philosophers of the world came out of the earth; that our planet, and the system of which it forms a part, should hold the elements of such men; that they should be struck from it as the spark is evoked from the flint-such facts as these should 


\section{RELIGION}

open our eyes to the marvels in which we live. But, you may say the spark is not evoked from the flint; it is the result of the collision of the flint with the steel, and represents the energy of the arm that wielded the steel - the spark is visible energy. True enough, and man was not evoked from the earth without some force or push in matter which our analysis of it does not disclose - an aboriginal intelligence which worked its will upon the atoms and molecules.

$\S$

That the roar of the tempest and of the volcano as they crush or consume towns and cities, is the voice of God, is a conception of Deity that belongs to an earlier age of the world. Yet these are all a part of Nature. What are we to do with them? There is no alternative but to dehumanize God and regard him as he actually is in the material universe which surrounds us, and of which we ourselves are an integral part - a part, at times, as irrational, as cruel, as destructive, as selfish, as frenzied, as the elemental forces out of which we came. The NatureGod is no better than we are, and we are as good as he is, we are bone of his bone, and flesh of his flesh, mere atoms and molecules in a corporeal frame that fills and is the universe. What the Nature-God does, we do; our mad, irrational warrings are matched on a vaster scale by his conflicting and destroying forces. Our intelligence is a spark of his intelligence, 


\section{FIELD AND STUDY}

our sanity, our beneficence, are feeble reflections of his sanity and beneficence. All is of a piece in this universe.

$\S$

Sooner or later, if one would not be divided against himself, he must face this terrible question of $\mathrm{Na}$ ture- of the Cosmos as a whole. Is it of God, or of the Devil, or of both? The pious souls seem long to have held that it is of both, that the more genial aspects of Nature - birds, flowers, streams, stars, sunsets, summer breezes, fair prospects - were of God, and that Nature's destructive, terrifying aspects and forces - storms, earthquakes, pestilence, wars - were of the Devil. Men have rarely had the courage to say that it is all of God, that it is all divine; that the cyclone, the volcanoes, the earthquakes, the thunderbolt, are as truly of God as are the forms and forces that directly please and minister to us.

We teach our children to say glibly that God is everywhere, in us and without us, above us and below us, and that in Him we literally live and move and have our being. Then when they ask us, Is He in the cesspool, in the cyclone, in famines, in the war, in all the dark and cruel aspects of Nature, we are at a loss for an answer. In his "Journal" Emerson asks, half quizzically, "Is God in a load of brick, is he in the barber-shop, and the bar-room?" When confronted with such questions we are forced 


\section{RELIGION}

to have two gods, a good God and a bad God, or else to give up all notions of a man-made personal God, - the awful maker and ruler of the universe, whom our fathers worshiped, and whose wrath we seek to shun or propitiate by our good deeds, either this or else the identification of God with universal Nature in all her multiform beneficent and malevolent aspects.

We seek to evade the issue by saying that God cannot be the author of evil; man himself is the author of evil; he is a free moral agent and can choose the evil from the good. But who made man? Who gave him the capacity to choose between good and evil? By whose laws is the distinction made? If he burn his neighbor's barn or covet his neighbor's wife or steal his neighbor's goods, does he create out of himself some new force or employ some new agent? Does his will have anything to do with his instincts, his temperament, his disposition, the color of his hair, the quality of his brain, his stature, his weight, his mental or spiritual endowment? Are not these things all of God, or from sources outside the sphere of man's voluntary activities? Hedge or qualify as we will, man is a part of Nature. His conscious opposition to Nature is also a part of Nature. Whence comes his capacity to use Nature, to improve upon her, to pit her forces against each other, but from Nature herself? Can there be anything in the universe that is not of the universe? 


\section{FIELD AND STUDY}

Can we make two or three out of the one? Is there an outside to the Cosmos, a beyond? Or an inside that is a world apart? When a man can lift himself into his carriage by his waist-band, or hurl a stone against gravity without the aid of gravity, or the swimmer overcome the resistance of the water without the aid of water, or sail his boat against the wind without the aid of the wind, or walk without that which resists his walking, then can man do some act or think some thought without the aid of Nature. These familiar facts or deductions of science Emerson has put poetically in his poem, "Brahma":

"If the red slayer think he slays,

Or if the slain think he is slain,

They know not well the subtle ways

I keep, and pass, and turn again.

"Far or forgot to me is near ;

Shadow and sunlight are the same;

The vanished gods to me appear;

And one to me are shame and fame.

"They reckon ill who leave me out;

When me they fly, I am the wings;

I am the doubter and the doubt,

And I the hymn the Brahmin sings.

"The strong gods pine for my abode, And pine in vain the sacred Seven;

But thou, meek lover of the good!

Find me, and turn thy back on heaven." 


\section{RELIGION}

The physician thinks he aids Nature, as he often does, especially in surgery, but it is only by the use of means which Nature has given him. He is a bit of Nature himself and can lend a hand to the struggling Nature within us. Man's use of Nature consists of short cuts; he abridges, cut outs the waste and delays, removes obstructions and directs forces in new channels. 


\section{III \\ SCIENCE}

T $\mathrm{N}$ my excursions into nature, science plays a 1 part, but not the leading part; it is like a silent monitor and friend who speaks when spoken to. Or I may say that I carry it in the back of my head and only now and then in the front. I do not go forth as an ornithologist taking note of the birds, nor as a botanist taking note of the flowers, nor as a zoölogist studying the wild creatures, nor as a biologist, peeping and prying into the mysteries of life, but as a nature-lover pure and simple, who gathers much through sympathy and observation.

I am committed to no specific object; my walk is satisfactory if I fail to add a particle to my store of nature knowledge.

$\mathrm{Oh}$, the wisdom that grows on trees, that murmurs in the streams, that floats in the wind, that sings in the birds, that is fragrant in the flowers, that speaks in the storms - the wisdom that one gathers on the shore, or when sauntering in the fields, or in resting under a tree, the wisdom that makes him forget his science, and exacts only his love - how precious it all is!

Love of nature does not depend upon exact knowledge, though exact knowledge has its value. 


\section{SCIENCE}

My interest in the rocks, in the fields, and in the cliffs above them is enhanced by what science has told me about them, but is not summed up by that. A knowledge of the fundamentals of geology greatly adds to one's enjoyment of the earth's features. Science is always a good seasoning, but one does not want too much of a good seasoning.

$\S$

How it makes one wilt to think of the vast time ahead of us - time to match the abyss of geologic time behind us! How trivial and futile seem all our ambitions and all our achievements in the face of the eternity to come! Consider only ten thousand years hence - a mere tick of the great Clock of Time - what or who will be where the nations are to-day? The natural philosophers think that life upon this globe may go on two or three million years yet. What a staggering proposition! Man has probably been man only a few hundred thousand years; with the brain and body he now has, only a few millenniums. What will he be in half a million years hence? Will any records or memories of our times last till then? Of course it is possible that some cosmic catastrophe may blot out our solar system before that time - possible but not probable.

$\S$

We use the term "celestial mechanics," and fitly enough, because the forces we see in operation are 


\section{FIELD AND STUDY.}

physical forces, but how radically unlike any mechanism we know among the bodies on the surface of the earth! With all our science and our mastery over the physical forces we cannot reproduce on any scale such a mechanism as that of the moon revolving around the earth, or as that of the earth around the sun, or as the revolution of the earth upon its axis. Every ball we project into space, by whatever means, spins on its axis, but it sooner or later stops spinning and falls to the earth; still the globe spins on through the ether forever. But to cause one ball to revolve around another without any tangible connection, as the moon revolves around the earth, is far beyond the reach of any mechanics we possess. We name two forces to account for the phenomenon, centripetal and centrifugal, but these names only cover a mystery. If there are two such forces at work, why cannot we invoke them in our mechanisms? Cosmic forces and cosmic laws transcend terrestrial forces and laws. They control the spheres and not the bodies on their surfaces. Perpetual motion is impossible among tangible bodies on the globe, but it is the rule in celestial mechanics. Our great cosmic poet, Walt Whitman, saw this: "There is no stoppage," he says, "and never can be." The whirl and dance of worlds and systems go on forever. The perpetual movement in the molecules of matter, in the infinitely little, goes on among the orbs of heaven, the 


\section{SCIENCE}

infinitely large. In celestial mechanies there is no friction; the dissipation of energy does not take place. How can the All either gain or lose? The Cosmos is a circle that has neither beginning nor end. On the earth's surface the laws of lines and angles rule, but among the orbs there is another law. All the work of man's hands involve detachment, discontinuity, beginnings and endings, under and over, falling and rising, but outside of the earth these conceptions do not apply. They apply only in the realm of parts and fragments. The sun, of course, dissipates energy, but can the sum total of the energy of the Cosmos be either increased or diminished? It is like the dissipation of moisture on the earth the water takes another form.

There has been but one cosmic poet, Whitman. The orbs occupy him more than they have occupied any other and all other poets.

$\S$

The slowness of the changes in cosmic nature is suggested by the changes in the period of the earth's rotation, which, philosophers calculate, has been lengthened about one three-hundredth part of a second since 720 years B.c. This is certainly holding the astronomical forces to a pretty rigid account. It seems that Whitman was not quite within the truth - the scientific truth - in his rhapsody on the earth when he said it revolved forever and ever in its own orbit without the un- 


\section{FIELD AND STUDY}

truth of a single second, but we may readily acquit him of any violation of poetic truth.

$\S$

It is not easy to think of invisible or of dark light, yet such exists. The ethereal vibrations produced by the discharge of a Leyden jar obey all the laws of optics, and yet the eye cannot perceive them; they are too slow. They are only from a hundred thousand to a million a second. What we call light is an experience or sensation of the eye, and the eye takes in only about two thirds of the vibrations that go out from the sun. Of the potent ultra-violet rays the eye knows nothing. The retina is incompetent to respond to these rays, they are so rapid.

All energy comes from the sun, and the machinery of the molecular process, the materialists tell us, determines what form it shall take, whether a plant or a man. But some agent or force must intervene between the sun and the elements, something must weave the force into different patterns. Do the molecules hold the pattern? Evidently the molecules of the man hold the pattern of the man, and the molecules of the frog hold the pattern of the frog, and of the cabbage and the oak, the same. But what did they hold before they entered into this copartnership? We have to postulate the organism to set up this weaving. Carbon and oxygen do not set up this weaving of their own accord in dead 


\section{SCIENCE}

matter. Before they act, something must have happened to them in that imaginary world of atomic motions and attractions. The solar energy was poured upon the earth millions of years before life appeared. While we know well that no life could appear without it, we know also that something happens to it before it appears as thought or love in the brain of man. I do not urge that something has to be added to physical forces to make them psychical, but they have to be changed, or raised to a higher power, through some agency that we cannot translate into human speech.

To reduce our mental and spiritual life to terms of physics and physiology is to reduce the flower to ashes, life processes to chemical reactions. The human heart is a pump, but is it not a pump plus something else? We recoil from the cold scientific analysis of any living thing, because the main thing, the life principle, escapes. Can you find the mind by dissecting the brain?

$\S$

How man's knowing faculties have come to the front during the past hundred years! Time was when his religious faculties and his emotions led all the rest, and his artistic powers went hand in hand with them. But now it is his understanding that leads. Now his desire above all else is to know things as they are in and of themselves. He is less religious, less artistic, less superstitious; his emotions take 


\section{FIELD AND STUDY}

a back seat, exact knowledge leads. This change has its unhandsome side. Life is in many ways less attractive. We have less veneration, less humility, less virtue than our fathers. Large, loving, picturesque personalities are becoming rarer and rarer, both in private and in public life.

In his practical life man had to follow his reason and common sense; he had to have a little practical science or perish, but in his religious and emotional life he was under no such pressure; he was free, and has always been free, to let himself go, to give unbridled range to his imagination; hence his fantastic beliefs, and his silly or horrible superstitions.

The earth grew as a whole like an organic being. The hemispheres kept pace with each other in their development. When the coal was being laid down in Europe, it was being laid down in America; when the chalk hills of England and France were being formed, chalk-beds were being deposited in our Southwestern States. When the Old Red Sandstone was forming in Scotland, an equivalent formation was being built up in this country. The great formative and deformative movements were worldwide. The continents are all built upon the same plan, a foundation of granite and a superstructure of sedimentary rocks, the different formations succeeding one another in regular order around the globe. Earthquakes and volcanoes are local; over- 


\section{SCIENCE}

thrusts and the crumpling of the earth's crust are local; but the periods of continental subsidence and declination seem to have been universal. When any part of Europe went under the ocean, some part of North America went under, and some part of Asia and Africa and South America.

We are prone to lose sight of the fact that large bodies are subject to the same law as small, that size does not count in nature. The earth is as much a unit, as much an organic whole, as an apple on a tree. In the development of life upon the earth the same thing holds true; no part got much ahead or lagged much behind the others, the different forms appeared in the same ages in the different countries.

Whether this came about through migration, or as the result of parallel lines of development, who knows? Was life at first local, and then universal by spreading? Was the horse, the camel, the elephant, the bird, at first local? Was man? Did he emerge in more than one country and age? If man, or any other species of animal, had but one single line of descent, how could that line have escaped being broken, throughout the appalling vicissitudes of geologic time? If each form of life had its centre or point of emergence, what was doing at other centres or points on the globe at the same time? If the Creative Energy worked through all matter why would it not focus itself at many points? Why only at one point? 


\section{FIELD AND STUDY}

If at any time during the past history of the globe there was but one pair of animals through which man could come, what a wonder that he ever got here! The conditions that produced a species in one part of the globe, would they not produce the same species in some other part? The vital, the physical laws are universal. Take Eocene times in this country and in Europe, and in Asia and Africa; was the progenitor of man in each of them, and was he the same in each? But all this is a pathless wood.

It is difficult to conceive of life as a tree with only one trunk, and starting in one particular part of the earth. It is easier to think of it under the image of the grass, at home everywhere. The old seas were universal; here life had its origin. In one part of that sea, or in all parts? When it got upon the land, was it at one point only? Or, to turn the question around a little, the seal, the whale, the manatee, are descendants of land animals. Did each race originate in a single pair that first took to the water? How Nature covers up her footsteps or wipes out her missing links! Foolish Nature!

$\S$

I love to dwell upon these different stages of world growth, and see in imagination how it fared with our continent during each one of them. The Cretaceous was evidently an age of low lands, especially in the southern and western parts of the 


\section{SCIENCE}

continents, of extensive inland seas, of vast calcareous deposits, of slow sedimentation, and extensive consumption of carbon dioxide. Most of the western coal measures were laid down during this age. With the reellevation of the land, the age of huge reptiles - the dinosaurs, the mesosaurs, the gigantic marine lizards - came to an end, and the period of mammalian life, the Tertiary, came in. During this period the borders of the continent, here and there, were under the ocean, from New Jersey southward, including the whole of Florida and a large part of the Gulf States and of Texas, but the interior of the continent was at last stable, and the sea never again encroached upon it.

$\S$

If the parts of the watch had an attraction for one another analogous to that of chemical affinity, or analogous to that which prevails among persons, it is not incredible that a watch might result; or if the letters of the alphabet, or if words had attractions for one another, intelligent sentences might result. The organs of the living body certainly have no attraction for one another, yet here they are working together to a single end. But to make a watch, even if the different parts attracted one another, must there not be an organizing principle something to make the watch a unit?

Chemical affinity results in water, it results in the nitrates, the carbonates, the hydrates, but no 


\section{FIELD AND STUDY}

conceivable attraction could result in the organization of these in a living body.

Chemical affinity builds up the nitrates, the carbonates, the hydrates, which in turn build up the living body, but under the control of something more than chemical affinity. Life could not result without chemical affinity, but chemical affinity cannot beget life; at least, it will not in our hands. We have to postulate the organizing impulse - the impulse under whose control many units work together to produce one whole, parts subordinated to parts and in which metabolism and reproduction and assimilation take place.

A rock is also built up of parts, but they are parts without function or purposeful relation. Chemical affinity plays its part, but brings about no change in the behavior or combination of the elements, whereas in a living body a host of new carbon compounds are developed.

\section{$\S$}

One of the strangest things in the world is that though we live all our days in an ocean made up of nitrogen and oxygen, yet one of the most difficult things for us to do is to capture and appropriate any of this nitrogen. We take it into our lungs, it bathes our bodies, in fact we cannot escape from it, and yet to seize it, to separate it from the oxygen, and make it unite chemically with some other body and fertilize our soil with it, is an Herculean task. It is 


\section{SCIENCE}

in the soil in the shape of air, but only certain plants can lay hold of it. Minute organisms can do it, and Niagara can do it, the thunderbolt can do it, but what else?

$\S$

After we have divided and subdivided matter mechanically to the utmost point, and reached the molecule, science takes the further step and divides it chemically and reaches the atom. Divide a molecule of water chemically and we get the atoms of hydrogen and oxygen - two of one to one of the other. Divide a molecule of common salt chemically and we get one atom of sodium and one of chlorine. Divide a molecule of lime chemically, and we get one atom of calcium and one of oxygen. Oxygen is one of two main elements in things so diverse as lime, air, and water - the magic of chemical combinations! When we breathe, we take into our lungs one of the main constituents of the rocks and of the solid ground under our feet. Our blood is red by virtue of the element that helps hold the world together. We eat and burn the stuff of diamonds.

The ring of six carbon atoms that make up the molecule of the diamond, and that is supposed to account for its hardness - how imaginary it is! The molecule of most of the elementary gases consists of two atoms of these elements. The molecules of oxygen and nitrogen in the air are not combined chemically, but are only mechanically mixed. 


\section{FIELD AND STUDY}

$\S$

Are we not safe in saying that matter certainly modifies itself, that its incessant physical and chemical changes are self-produced? At any rate, there is self-activity in the material universe, perpetual motion of the whole - a whole without boundaries, which seems a contradiction. Perpetual motion of a part is impossible; that is, without drawing upon sources of energy outside itself. And perpetual motion where nothing is at rest is another contradiction; the motion of the whole is equivalent to the rest of the whole. A balloon drifting in the air is at rest with reference to the moving air.

Why the forces of the universe do not find their equilibrium - the angle of repose, the state of a uniform temperature - who knows? Its energy is stored in the atom as potential energy; what is it that converts it into the energy of motion? According to the principles of mechanics should we not expect the vast machinery of the universe to run down, or the motion of matter to cease or become only potential? We cannot think of the energy of the universe as being dissipated out of itself; there is no out of the universe. Energy can only be transformed, not destroyed; it must persist somewhere. Archimedes might have moved the world had he had a place outside the world from which to bring his power to bear.

We can think of the entities as acting upon one 264 


\section{SCIENCE}

another, but how can a mechanical force act upon itself? How can a body fall unless there is some other body for it to fall to? The earth falls toward the sun, but never gets there; the sun falls toward some other greater sun, and that toward some other centre of forces, but what can the whole universe fall toward?.Is it not like asking, Will the puppy ever overtake his own tail? The self-activity of the universe seems to me as impossible as any perpetual motion machine ever dreamed of. Power moves down an incline of temperature or gravity or a gradient of some sort. There must be inequality and fixed points. The inertia of the gun resists the explosive power of the powder and hurls the ball; the resistance of the ground enables us to walk. Power is available to power. To avail ourselves of gravity we must first overcome it. We must lift the lever up before we can ask gravity to pull it down. We have to pit gravity against gravity.

The low uniform temperature of the ocean holds enough potential power to drive all the ships on its surface, and more, if we could only bring it to bear - create an incline down which it could flow. But this would require an equal power. Then there is an incline of temperature from the southern oceans to the northern that causes the great ocean currents, but their power is not available, because there are no stable shores to their rivers upon which to plant our machinery. 


\section{FIELD AND STUDY}

$\S$

How to connect our psychic life with the physical is just as hard a problem to science as how to connect physical life with inorganic nature. The breach of continuity seems the same in both cases. How the spiritual can arise out of the material, and connect with it, is beyond the reach of science to explain. The life of man, the life of the soul, seems as limited and uncertain, when seen on the vast background of vegetable and animal life, as does the latter when contrasted with the volume and permanence of the inorganic order. Man's supreme gift of reason was long in coming to the race, and it is long in coming to the individual, and it comes in full measure to one, and in scant measure to another. It is like an extra and fortuitous gift. The great mass of human life is merely a complex of animal instincts and inheritances; free intelligence plays but a very small part in the sum total. How easily is the reason dethroned and the mind reduced to chaos; a fall, a blow on the head, fear, misfortune, overstrain of any kind, and reason may be gone.

$\S$

If light is not a substance, or an independent entity, but only a process or a mode of motion, in a substance, the effect of which upon the eye we call light, why may we not think of mind or soul in the same terms? - a molecular motion in the brain which gives rise to the phenomena we call mental? 


\section{SCIENCE}

There is no mind apart from mind, as there is no light apart from the eye; there are only the vibrations in the ether which give us the sensation of light.

The mind turns, so to speak, and regards itself. Reason looks reason in the eye and judges it - an impossible feat tried by any physical standard. The eye can see all things but itself; the body can move itself, but cannot lift itself; in lifting we press downward with the force we exert upward.

When a certain molecular motion in the brain ceases, the mind ceases, and presently another molecular action in the brain substance, called dissolution, or putrefaction, sets in. The mind has not gone somewhere, any more than the flame of the candle has gone somewhere when we blow it out. Its elements still exist, but their combinations have changed. The heat has gone into the great sea of uniform temperature and has changed it no more than a drop changes the ocean. So far as I can see there are no terms in which we can discuss the reality of the soul except in the terms of physical bodies. To discuss it in theological or metaphysical terms is like trying to weigh shadows.

The amount of matter now on the earth that has once formed or been through the human brain is considerable - water, lime, phosphorus, iron, and so on. This matter has gone through what we call the psychic world. How it has been impressed by it 


\section{FIELD AND STUDY}

we know not, but I like to think of it as having acquired some new power or susceptibilities, or as being more and more ready and available for the psychic sphere. It ought to be easier to people the world with great men now than in any earlier time, though it would be hard to prove that it is. It is certain that the brains of vertebrate animals have increased in size in late biologic time, and that the brains of our forbears steadily increased through the late Tertiary. The historic period is probably too short to measure the increase of mind-power.

This is discussing the question in terms that have a definite meaning to us.

That consciousness, which is as much the result of the action and reaction of matter as a flame is, can continue irrespective of matter, is unthinkable. It is certain that light and electricity cannot exist apart from matter. Mind seems, and is, very real to mind, but it is has no reality to our bodily senses. If we had no capacity for love ourselves, could we recognize love, or anger, had we no capacity for anger? One cannot get behind himself and see what his consciousness is like. One can lift another, but not himself.

Things very real to us utterly cease to be. Things which have no reality in themselves, like shadows, and tracks in the mud and snow, impress us like real things. 


\section{SCIENCE}

$\S$

As the human mind advanced in the study of natural causes, or in scientific knowledge, the time was bound to come when it would ask for a scientific explanation of life itself. The old teleological conceptions could no longer satisfy it. It must find the reason of things in the things themselves. Its science reveals to it worlds within worlds, deep beneath deep, at the same time that it shows the universe to be one, rounded and complete in itself, and that there is nothing more potent or mysterious than the common elements and forces that are involved in our daily lives.

Life is a physical phenomenon; is it therefore capable of a physical explanation? The only explanation science can give must be a physico-chemical one; it would be transcending its own sphere to give any other. The only explanation it can give of death must be a physico-chemical one. For any other explanation of life or death we must appeal to our philosophy or to our religion, which is our philosophy suffused with personal emotion. Science must and does seek objective proof; philosophy and religion seek the approbation of the reason and the intuitions. The question is, have either of the latter authority over science on such a question as the nature and origin of life? Many men of science say "No" with emphasis. Long study of the chemistry and mechanism of life convinces such men 


\section{FIELD AND STUDY}

as Haeckel, Verworn, Tyndall, Huxley, Schäfer, Loeb, and others that life is a product of the material forces, while minds with a philosophical and religious turn, like Sir Oliver Lodge and Henri Bergson, and others equally eminent, feel compelled to invoke a psychic or transcendental principle to account for life - something in matter but not of it.

For my own part I can do nothing with such a question without some sort of philosophy. Science is convincing as far as it goes; it shows me how inevitably life is bound up with the physico-chemical forces, but when it has finished its explanation I feel constrained to ask, "Is that all?" Is a description or analysis of life-processes an adequate account of life itself? Is a living body only the sum of its physical and chemical forces? Is a man, for instance, like any other mechanism, only the total of the parts and elements which a chemical and physical analysis of him reveals? Does not the unity of a living body have a significance which a mechanical unity does not have?

$\S$

It seems almost paradoxical that deep-sea fishes, subject to a pressure of thousands of pounds to the square inch, should have tender and loosely knit bodies. One would think that such a pressure would beget very firm and compact bodies. Is it to be inferred that if the atmospheric pressure upon our 


\section{SCIENCE}

own bodies were many times greater than it is, our muscles, too, would be soft and flabby? We are entirely unconscious of this pressure and our movements are not at all hampered by it. But if we could step into a room or an enclosure from which this pressure were removed, we should probably come very near exploding, as do the deep-sea fishes when suddenly brought to the surface. Doubtless under higher pressure our bodies would be much smaller than they are, as all the deep-sea fishes are very small - only a few inches long. Toward the surface they increase in size, and we find the whale, an airbreathing animal, the largest of ail. Does it follow that under a lighter atmosphere our bodies would be larger and firmer? A low barometer, a condition of storm, means a light atmosphere, and if we are conscious of its effect at all, it is a sense of weight; while a high barometer gives us a sense of buoyancy and elasticity. The men on Mars, then, other conditions being the same, should be larger than those upon the earth. But the forms of life on Jupiter, Saturn, Uranus, and Neptune should be smaller, because these planets all have very dense atmospheres.

Nature in the deep sea is the same old equivocal Nature that we know at the surface - hesitating, fickle, contradictory. The effect of the darkness in the abysmal depths upon some forms is to make the eyes very small, or to obliterate them entirely, 


\section{FIELD AND STUDY}

so that scales grow over the places where the eyes should be. In other cases the effect is precisely the opposite - the eyes are larger, becoming in a few species like enormous goggles. 


\section{IV \\ EVOLUTION}

7 VOLUTION has been a hard road to travel, 4 but are not all roads that lead upward more or less hard? The downward roads are the easy ones - the road of degeneration or devolution - no pain, no struggle, no effort, only placid acquiescence.

The sea squirt begins life as a free, active little fish, a simple vertebrate with powers of locomotion; but it soon takes the road of devolution instead of evolution; it attaches itself to a stone, or a shell, or other fixed object, loses its special sense organs and the beginnings of a backbone, and becomes a "mere rooted bag with a double neck." The barnacle takes the easy downward road in the same way, degenerating from a free, swimming, six-legged, compound-eyed creature, like a young crab or a shrimp, into a mere immovable shellfish attached to a rock or a ship-bottom.

\section{$\S$}

The main factor in the progress of evolution is, of course, the tendency to variation, and this tendency seems to become more and more pronounced as life proceeds and becomes more complex. It is more pronounced in the higher forms than in the lower. This fact doubtless accounts for the more 


\section{FIELD AND STUDY}

rapid strides of evolution in later geologic time. The chances to win become greater and greater. More and more doors are opened, more and more new ventures are made. Where the invertebrate had but few chances of becoming a vertebrate in Silurian time, the variations were so slight and so slow, the reptile had many more chances of becoming a mammal in Mesozoic time, because the principle of variation was so much more active.

As an animal's wants increase, the more strained will be its relations with its environment; and, the more it is out of sympathy with its environment, the greater will be the variation. The cows along the St. John's River in Florida spend much of their time knee-deep or deeper in the water, grazing on the grassy bottom. They are out of sympathy with their environment. Should this continue long enough, no doubt these cattle will begin to show some marked variation toward a better understanding between themselves and the St. John's River.

When we reach man, the tendency to variation is more pronounced than in any other animal mental variation. Had this not been so, man's progress had been much slower. The rank and file of mankind have been led forward by a few minds that varied vastly from the common type. There have been favored races and favored states and favored ages and favored families in this respect - one brother differing from another as day from night, 


\section{EVOLUTION}

mediocrity every now and then blossoming into genius.

The progress of man must have been very slow even after he got up off from all fours. When he hit upon a language that went beyond the emotional language or cries and calls of the lower orders, and stood for ideas, mental processes, his progress must have been greatly accelerated. Then when he invented tools and weapons and began to acquire some mastery over outward nature, he took another tremendous stride forward. Then his social and family instincts were a great gain. It is true the lower animals have these and yet do not progress. In man there is from the first a new capacity educability, as Lankester calls it - and this makes every step forward an incentive to another step. Something in him invented a language beyond that of the brutes; this reacted upon him and stimulated his mental growth. The family and social life reacted upon him and stimulated his powers of organization and awakened his spirit of altruism. He differs from all other animals in the nature of his reactions. There is something in him that profits by all his experiences. He learned to think. What a stride was that! It gave him the use of fire, of the wind, of the currents. His reaction is a bound upward. He began to see things external to himself and to consider his relation to them. In his language he stored up mental power which the lower animals do not. He 


\section{FIELD AND STUDY}

was the first animal to see things as they are apart from himself. We see this in his first rude drawings while he was yet a cave-dweller, and in the ornamentation of his weapons and tools. He was the first and only animal to see wholes, as well as parts, to see the landscape, the sky, the stars. He looked out and up. Your dog heeds the rain and the snow, but he does not heed the gathering clouds; he sees the fox or the rabbit, but not the prospect their course opens up to him; he profits by experience, but he does not accumulate a store of knowledge.

When man first developed wonder, awe, reverence, superstition, he had got well launched upon his career.

How the darkness deepens as we go back into prehistoric times. Man's rude stone implements shed the last ray of light. When we get back into geologic time all is black night save as the strata reveal the remains of his forbears.

$\S$

We seem to see life like a traveler on the road hastening as it nears the goal. Who knows how many millions of years it lingered with the first low marine forms, or how many with the first invertebrates, or how many more with the fishes, or with the reptiles, or with the huge mammalian forms? It seems as if it began to hurry in the middle, or Mesozoic, period. When the lemurs and baboons were in sight in the Cenozoic age, it quickened its 


\section{EVOLUTION}

pace still more. From the apelike man of the latter part of this period it made rapid strides till the first rude man appears in the Quaternary age. His remains appear so suddenly as to give some color to the special creation theory.

\section{$\S$}

To those persons born and educated during the last thirty or forty years the idea of evolution and of our descent from some lower animal form cannot prove so new and startling a doctrine as it was to those of us who were born and schooled fifty or more years ago. These things are in the air now and go along with the whole progress of physical science. But prior to Darwin's time, and long after the publication of his "Origin of Species," the idea of our animal ancestry was simply shocking, and, to the vast majority of minds, unbelievable. All our creeds and traditions and most of our science, to say nothing of our instinctive pride of origin, stood in the way of its acceptance. Our eyes had not yet been opened to the true wonders of nature and how divinity hedges us about.

\section{$\S$}

All through the early geologic ages life was diffuse; a steady concentration has taken place as time has gone on. As life became more complex it became less broadcast and haphazard. This was the condition of progress; more organization, more division of labor, more specialization; from vague, 


\section{FIELD AND STUDY}

irresponsible mob-life to the unity of organized and law-directed life, as in human progress; from myriads to scores or hundreds; from the chance of winds and waters to parental care and protection.

The first life multiplied by fission or division; later the stage of egg-laying was reached. The fish lays thousands of eggs and trusts to luck; the higher insects such as the ants and bees lay few eggs and care for them and nurse the young. The more intelligence, the more restricted is reproduction. The element of chance has less play; there is less waste, more system and less risk. The progress of nature in this respect suggests the progress from rude pioneer life to our more specialized and intensive life. The fish produces thousands of eggs, the amphibian hundreds, the reptile tens, the birds five, the mammals one. Nature is lavish only with her lower forms; free with her pennies, but stingy with her dollars.

$\S$

"There is no innate or necessary tendency in each being to its own advancement in the scale of organization," says Darwin; yet he says there is in all living forms an inherent tendency to variation that is, to push on and out in all directions, an inherent activity or push of life, just as there is in a fountain to flow and make itself a channel. Is not this the necessary tendency that Darwin denies? The fountain may vary its course every rod by rea- 


\section{EVOLUTION}

son of obstacles in its way, but it would not vary at all were it not for the push of the water behind it. The inherent tendency to vary implies an inherent force or effort. Only living beings struggle; it is the characteristic of life to struggle, to push on. The mechanical forces do not struggle, they clash and seek repose; vital forces struggle and seek ascendancy; the body struggles against disease germs, and the germs struggle against the body; it is a trial of strength.

$\S$

What natural cause keeps any species of animal in check, or accounts for its superabundance, is a question not easily answered. Take our common red weasel, for example: it is very hardy and prolific; it has few or no natural enemies; it is active and fearless; it can climb trees and is nimble on the ground; it preys upon a great variety of small rodents and birds, having such power over them that it overtakes and kills the rabbit, which is much more fleet of foot; and yet it is one of our rare animals; one would say there are hundreds of rats, chipmunks, red squirrels, and rabbits, to one weasel. Though I live in the country and spend much time in the fields and woods, I do not see on an average one weasel in a year. What keeps them in check? Some, to me, unknown factor. In our country the flesh-eating animals are rare in comparison to the non-flesh-eaters, or to the miscellaneous 


\section{FIELD AND STUDY}

feeders. The more varied an animal's diet, the more the animal abounds. How vastly more numerous the crows than the hawks! The crow is an omnivorous feeder. Rats and mice are omnivorous feeders. Bears have a wider dietary than wolves and cats. Squirrels are wide feeders. Weasels are very narrow feeders; they are blood-suckers. The purely insectivorous birds are less numerous than the birds that feed on both seeds and insects. The English sparrow is an omnivorous feeder, hence its numbers. Some birds seem to have a fuller measure of life than others, - our robin, for instance. What a hustler - breeding three times during the season!

$\S$

Life to most creatures is both a battle and a festival. The Darwinian struggle for existence is a battle of varying degrees of intensity, while the breedinginstinct, which is the central and dominating fact in all animal life, gives rise to the festival. True it is that the festival is at times red with battle, and the battle may have gay and festive moments, but on the whole the two phases of life are pretty clearly defined.

$\S$

How are we going to reconcile the rule of universal nature, that might makes right, that the strong do and must prevail over the weak, with the ethical and individual standards by which we try to conduct our lives? Is there any ground of recon- 


\section{EVOLUTION}

ciliation? Is the idea as unthinkable as that two and two make five? or as that a part is greater than the whole?

The whole tremendous drama of evolution, from the first unicellular life up to man, and from the dawn of history to the present time, illustrates and confirms the idea that power does prevail and has prevailed through all time, in the organic and in the inorganic world. The weak go to the wall, the battle is to the strong, the race is to the fleet, the wind is not tempered to the shorn lamb. Inferior races give way to superior, savage man goes down before the more civilized, science crushes ignorance and superstition.

Professor Osborn in his "Men of the Old Stone Age" shows how race succeeded race in Europe tens of thousands of years ago, and that a growth in brain was a growth in power. Do we not see that in every community, every neighborhood, the strong men prevail over the weak - brains, knowledge, judgment, accumulate the wealth, build up the big business, shape the policy of the state and the nation? It is as inevitable as are gravity and cohesion. The ideal in this respect is the man who in the competition of life succeeds by perfectly fair means, by superior industry, skill, judgment, economy, who not only lifts himself up, but carries the community up with him. That success is often attained by unfair means does not invalidate the principle. 


\section{FIELD AND STUDY}

The confusion and contradiction in our minds on the question of might versus right begins when we introduce our moral standards into universal problems. Right is a relative and limited term. Nature outside of man knows it not; she knows only power, progress, success. Right and wrong apply to our conscious human conduct, and not to the processes of Nature. It is wrong for me consciously to cheat my neighbor; it is right for me to be a better farmer, a better mechanic, a better tradesman than he is, and thus win over him in the competition of life. Natural right and moral right are two separate things. It is not wrong for fire to burn us, or floods to drown us, or disease to consume us; it is only natural. Winds and waves are guiltless, no matter how much we suffer from them. When there is no conscience, there is neither right nor wrong. Our natural rights are limited to the use of the means by which we can make the most of ourselves without hindrance to others.

Where, then, in human affairs are we justified in saying that might makes right? Only in those cases where results flow from causes that are over and above our conscious wills and purpose. Power will make itself felt. Natural law rules largely in the human realm.

Shall the meek inherit the earth? Can they? Suppose the law of love, of good-will, of coöperation, of doing to others as you would be done by, had pre- 


\section{EVOLUTION}

vailed throughout the biological and historical ages, instead of the rule of the strong, of the dominance of might over right as we see right; suppose one species had not preyed upon another, the bird upon the insect, the cat upon the mouse, the lion upon the antelope, the carnivorous upon the herbivorous and the graminivorous, or one tribe of man upon an inferior tribe; instead of all this, suppose the rule of justice, of fair play, as we see them, - gentleness, meekness, pity, the strong giving way to the weak, the little fishes favored by the big, - what would have been the probable effects upon the course of organic development? Could the process of evolution have resulted in the higher forms? If all $\mathrm{Na}$ ture's ways were ways of gentleness and justice and love, where would the living world be standing to-day?

Or, if we confine our consideration to man alone, what would his development have been had the rule of love and disinterestedness prevailed? Could there have been any progress? If the Cro-Magnon man, of which Professor Osborn writes so lucidly, had not forced to the wall the earlier type of men, would Europe be what it is to-day?

Does not our supposition strike at the very foundation of development? Would there have been any superior races, any ascent in the scale of life, had not the strong prevailed over the weak?

Does the question of right and wrong come into 


\section{FIELD AND STUDY}

the consideration of the matter? Do our human standards apply in the struggle of organic evolution? Is it right for the bird to devour the worm or for one insect to destroy another? or for the big fish to eat up the little fish? or for the wolf to devour the lamb? See to what straits our standards of right and wrong lead us! In nature that is right which succeeds; unless might is successful it is not might the other side is might, and therefore right.

Start this flame of life going and it goes on. The world is full of matter that is combustible to it; the very foundations of the globe are its material. But how to get the first spark? The Promethean fire we do not need to steal from heaven; we can kindle it by mechanical and chemical means any time; but the fire of life we cannot kindle. We have to evoke it from heaven, by means of a miracle. And how it differs from the other! The fire of life burns its own ashes over and over. Yet Science asks, Is there any more reality to vitalism than there would be to igneousism?

$\S$

The need begets the tool and the tool begets the need. The need begat the saw and hammer. There was this activity, this push of life, this feeling of struggle behind it. Man would have had no tools or weapons or inventions had he not had a ceaseless and irrepressible feeling or desire to extend himself, 


\section{EVOLUTION}

to subdue and possess the world. Whence this feeling? Is it, too, of mechanical origin? Is it the same throughout organic nature? The seed does not feel the need of wings, but something feels it. All seeds need to be distributed, hence their hooks, and wings, and springs, and other devices. The nuts need to be distributed also, and the animals do it in their own behoof, and Nature gets what drops from their tables. The jays and crows lend wings to many nuts. The red squirrel lends feet. The push of life again, the procreant urge and urge of Nature. The expansive forces of inorganic nature are mechanical, but this push of life is another matter. The necessity for teeth begat teeth, but there would have been no necessity had it not been for this expansive or progressive force of life, this push of development; and whence this comes, who knows? This push is not in inorganic matter.

\section{$\S$}

When we look at the problem of life through the eyes of the idealist and visualize its phenomena, we seem to see life as something incalculable and mysterious in nature. It appears like a visitant from another sphere. It seems utterly foreign to all merely mechanical and chemical processes as we know them in unorganized matter. These forces go their unceasing round seeking a stable equilibrium, the vital forces go through their cycle seeking an unstable equilibrium. Life breaks up the old routine 


\section{FIELD AND STUDY}

of the mechanical and chemical forces. It does not annul them, but it makes use of them for its own behoof. See these forces careering over the earth's surface for untold ages, going their endless and fateful rounds, dissolving and re-forming the rocks, making the soil, clearing the atmosphere, depositing the clay-banks, the sand-banks, the gravel-banks, the marl-banks, the phosphate-banks, scooping out the valleys, laying the foundations of the hills, collecting the waters into the rivers and lakes and seas, establishing the weather-system of the globe, providing for the rains, the snows, the dews, - matter and energy supreme, knowing no master, the only activities in matter mechanical and chemical. Then suddenly, or gradually, as you please, a new activity appears, the vital, and after long ages a new power, the mind and soul of man. The mechanical and chemical forces have found their master. Man turns them into new channels, or reverses them and takes all sorts of liberties with them. He makes them do his work, he combines and coördinates them in a way they were never combined before. Psychic power is the master of the physico-chemical power. $\S$

Life creeps or swims before it can walk, and it walks before it can fly. It feels before it can see, and it sees before it can hear or smell. It has sensation before it has perception. It has instincts and reflex actions long before it has consciousness and reason. 


\section{EVOLUTION}

It has nerve-ganglia and a spinal cord long before it has a brain. It has a notochord before it has a spinal cord. It feeds before it has a stomach or a mouth; it moves before it has limbs. It has a body before it has a head; it multiplies before it has sex.

The muscles of our trunk are inherited from the tubular body-wall of worms; the shoulder and thigh muscles were developed by fish to move the fins. Arms and legs grew stronger through a long series of generations of amphibians and reptiles. Hands and fingers were developed by arboreal animals. These mature in the same order in the human child today. Our muscles grow younger as we pass from the trunk outward to the fingers or downward to the toes. The muscles of the neck are very old, those of the jaws are younger, those of the tongue and lips and the muscles of expression are younger still.

"Late in Tertiary times primitive man or his anthropoid ancestor forsook the trees and lived upon the ground."

The gigantic forms in animal and in vegetable life largely gave place to lesser forms in both spheres. With the advent of the lesser forms in animal life came an increase in the size of the brain, muscular power declined and a new kind of power, nerve power, came in. Yet not in all forms; the horse went up from small to large, so did the elephant, so did man, and a few other forms.

Size and power seem by no means to have been 287 


\section{FIELD AND STUDY}

the determining factors in the evolution of species. The early gigantic forms all disappeared, and lesser forms finally came into possession of the earth.

How the machinery for eating and fighting developed before the machinery for thought developed! Behold the size of the under parts of the heads of the mammals below us - all jaw and mouth. When the cow or the horse pauses and looks at you, - no, they do not look, they stare, - when the cow or the horse pauses and stares at you in that blank kind of way, one wonders what is passing in that small cupful of brains at the top of their long, bony heads. Not thought surely, yet some kind of molecular activity. Yet the bird has a much larger brain, in proportion to its body, than has man, and the ant much larger than the bird. Our yea-and-nay methods are inadequate to deal with nature. 


\section{NATURE AND NATURAL HISTORY}

7 HE bluebird is a bird without fault. All its

1 ways and sounds and habits and looks are pleasing. It neither eats your fruit like the robin, nor daubs your porch with mud like the phœbe, nor brings a plague of bird lice as the latter often does. It is half-domestic like robin and phœbe without any of their vices. It does not awake you in the early morning, nor tease your ear at any time of day with its persistently reiterated notes. As an insect-destroyer it must equal any of them, and as a harbinger of spring it is the most welcome of them all. It comes to its nest and young in the hollow of the limb on the corner of my porch as softly as a shadow, and when feeding its young it comes about every minute nearly all day, till the twilight deepens. All its ways are ways of gentleness. It is a bird without snap or emphasis or sharpness of any kind. I always visualize its note as blue like its back. Its wing gestures are as pleasing as its note. The bird has the quality of the thrush, with a touch of something cerulean.

Certain of our familiar birds, like the wren, get on your nerves. Even the darling song sparrow will, at the height of its season, go through its repertoire 


\section{FIELD AND STUDY}

of five songs before your door till you are fain to cry out, "Oh, do take a rest!" But from first to last, from April to October, or November, the presence and the voice of the bluebird has the effect of harmony and repose - soothing, tranquillizing. Not a song-bird, strictly speaking, it does not strike an attitude and lift up its voice in a definite series of notes, like the song sparrow, yet its every sound and call is musical, and its every movement harmonious. Our fine songsters play their parts well, but their period of song is brief, while the bluebird - well, is always the bluebird. It keeps its tone and quality the whole season. How engaging is the habit it has in late September or October of coming back to its deserted nesting-places and lingering fondly about them! One cannot be certain whether it is the parent birds, or some of the young, that return. They peep into the cavity, warble softly to each other, and then take turns entering it briefly. It is emphatically a home bird. In my bird heaven the bluebird shall occupy the nearest porch and shall always comfort me with his gentleness and composure. I should tire of the Old-World lark and the nightingale as hourly companions; they are too sharp and vociferous; but the bluebird is as soothing as the blue sky itself.

\section{$\S$}

The most amusing bluff that I know in wild nature is that put up by the male wasp when you seize 


\section{NATURE AND NATURAL HISTORY}

him in your hand and he makes believe sting. $\mathrm{He}$ goes through with an exact series of movements that ought to cause you to drop him as you would a red-hot coal. He curves his body and thrusts out the stinging end right and left most viciously, feeling for a vulnerable place on your flesh and protruding a sort of stinger-scabbard minus the stinger. The sight of it all fairly makes one wince. Of course, he does not know he is bluffing, there is no such word in his dictionary, but he seems to think he is punishing you severely. It is as if a soldier in battle were firing blank cartridges without knowing it. You may know the male wasp by his yellow face. Beware of the black-faced ones.

There is a good deal of make-believe in the play of animals, but I recall nothing analogous to this bit of serious acting of the stingless wasp. Certain bugs will feign death and drop to the ground, but I know of no mammal that will do so. To decoy their enemies away from their nests and young, groundbuilding birds will feign lameness and paralysis, but this is an instinct that serves a different purpose than that of the stingless sting of the male wasp.

$\S$

As Nature has dowered man with more and higher gifts than she has any other creature, so it may be said that she has, on the other hand, been more cruel with him than with any other animal. More enemies beset him, more hostile germs prey 


\section{FIELD AND STUDY}

upon him than upon any other creature. His list of dangerous diseases, from which the lower animals are practically immune, is a long one. He pays a big price for his gift of reason. He makes more mistakes and suffers more accidents than any other creature. He has invented tools and explosives and he is maimed or blown to pieces by them. He has invented destructive weapons and he is the victim of devastating wars; he has conquered the sea at the risk of shipwrecks and destruction; he has at last conquered the air and in so doing has opened the way to new failures and catastrophes. Every advantage has its price; every new conquest has its attendant perils. Human reason takes man out of the safe round of the uneventful lives of the lower orders; new enemies, new perils, new anguish, are the prices paid for new achievements.

$\S$

The cunning of the fox is proverbial, but see how his wit fails him under absolutely new conditions! Dan Beard tiells, in his delightful "Animal Book," of two tame red foxes that he once had and that he kept chained together. At night they used to prowl about the neighborhood a good deal and they frequently came to grief in this way; they would each try to go through separate holes in the fence or hedge, when, of course, the chain would bring them up short; and they never learned the trick of one following the other through the same hole. A mere 


\section{NATURE AND NATURAL HISTORY}

fraction of the cunning and sagacity that they showed in the line of their inherited instincts would have led them to do this. But the chain was a new thing; artificial conditions had been imposed upon them; there had been no chains and collars in the fox traditions; hence their inability to extriaate themselves from the conditions in which these things involved them.

And yet the fox knows pretty well how to deal with a new thing in the shape of a steel trap. Yes, because the trap awakens his inborn cunning and suspicion, while the chain that held Dan Beard's foxes got them into difficulties that had no such effect, and that called for powers of reflection rather than traits of cunning.

The lower animals do not reflect, do not return upon themselves and consider the means to an end. When they use the means it is from an impulse, and not from a thought. Do you suppose, for instance, that the oriole has considered the advantage of strings and horsehairs in the building of its nest? or the cliff swallows the advantage of clay mud over muck or other materials?

\section{$\S$}

Who that has seen trained seals has not been struck with what appears to be their remarkable intelligence? Yet the Bering Sea seal commissioners had this experience with them: At the killing time they tried to separate the young males or "kill- 


\section{FIELD AND STUDY}

ables" from the old ones of the same band by driving the herd through a wooden chute or runway, with two valvelike doors, a small one and a large one, at the end. The small door would open for the small seals, and the large door for the large ones. But the seals persisted in following one another. The most experienced males would beat their noses against a closed door through which they had seen the seal before them just pass. That the door had been shut, and another, larger, one opened beside it made no difference.

$\S$

Some friends of mine caught a fish called a searobin and kept it confined in a large pan of water for a day and a night. The fish continually swam round and round in a circle in the pan, seeking an outlet, so that when they finally carried it out in the bay and let it go, it continued to swim around in a circle. They carried it farther out, but it was still confined in the pan to all intents and purposes, and they left it.

$\S$

Sometimes in confinement an animal, if left alone, will give us a glimpse of its real mental makeup. I am thinking of Mr. Beebe's account of the wood ibis at the Bronx. The bird would "stand in a cement-lined pool and for hours patiently tap the bottom with its foot, trembling with eagerness the while, as he watches for impossible worms to come 


\section{NATURE AND NATURAL HISTORY}

to the surface." The bird at such times is a mere automaton, impelled by its inherited memory. No doubt that in the laboratory this habit could be broken up, and a new habit formed in its place.

$\S$

One autumn morning just at break of day a friend of mine was sitting in a hemlock-wood beside a little trout-brook, waiting for partridges to begin to move. As he sat there he heard something coming up the stream toward him, splashing in the water and rattling the stones. Presently he saw a raccoon coming up the stream, turning over the stones in the shallow water, and feeding on something beneath them. What was surprising, the coon turned the stones over with his nose, and not with his paws, as one would have expected. So deft and handy is the coon with his paws, and yet he rooted the stones with his nose like a pig.

$\S$

Cowboys tell me that when one of their herd gets mired, and they have to rope it and drag it out, the first impulse of the beast is to gore its rescuers. It has no conception of the service that has been rendered it. The mire and the ropes and the rough usage enrage it, and it seeks to avenge itself upon the herdsmen. Just so will a dog or a cat, caught in a trap try to bite the hand that liberates it. 
What an uncertain and accidental thing seems the gift of long life! It comes to the just and to the injust, to the wise and to the foolish. It is as indiscriminating as the rainfall. I see almost daily a man walking the street here, going to a saloon for his glass of grog, who is ninety-three. He never had much intellect, and it seems to have grown less and less as the years have passed. In my youth I knew a man, a very ordinary person, who lived to be considerably over a hundred; he lived alone in his last years, and lived much like a beast. The length of his years was no measure of his worth to himself or to his fellows. Only recently a man in Sullivan County, a common laborer, but a worthy man, is said to have reached the great age of one hundred and twelve years. I know a sculptor who went up there and made a bust of him. An old fellow in my native town lived to be eighty-three, and was drunk much of the time, often lying out half the night in cold and storms. I happen to think of him now because I saw his name recently in the cemetery. Sir William Temple relates that he had known two persons who lived to be over one hundred and twelve, a man and a woman - the latter a servant, the former a common laborer.

On the other hand, how many men of invaluable service to the world fall by the wayside before they have lived out half their days. If, with his tre- 


\section{NATURE AND NATURAL HISTORY}

mendous vitality, Roosevelt had also had the gifi of length of days, our debt to him would doubtless have been even greater than it is. Surely the gift of length of days is neither a wage nor a reward of merit. You have it, or you do not have it, and the Lternal is indifferent. It is hard to kill a man who lias it, and it cannot be bestowed upon a man who has it not. How vain to try to find anything like our prudence, our economies, our foresight in the ways of Nature! Nature is a spendthrift and a miser, both at the same time.

\section{$\S$}

Nearly every season, in early fall, after days of wind and cloud and rain, there comes one of those still, clear, breathless mornings - the first fall hush in nature. Every sound by man or beast stands out on the great background of silence. The distant barking of a dog, or lowing of kine, or cawing of crows, carries far. The very air seems resonant. I hear the clucking or chucking of a chipmunk far off. Then the call of a solitary robin strikes my ear. A moment later from the orchard comes the bur-r-r-r-r of a red squirrel. Then $I$ hear the scream of the jay in the beech-woods. The slightest sound breaks the great stillness as a pebble starts the ripples on a smooth surface of water. The fog in the valley barely stirs, like a half-awakened sleeper. It has not energy enough to creep up the hill. A few mornings ago it wallowed up to our doorstep and lay down 


\section{FIELD AND STUDY}

upon it for half an hour. It was an unwelcome visitor; but this morning the sun is working its magic upon it and will leave no trace behind. In certain conditions of the atmosphere the valley fog is slowly burned up where it lies; at other times it ebbs and flows, rises and sinks at intervals like the lava in a crater. It comes up over the hills three or four hundred feet above its night level, then withdraws, then returns. It does this several times as if seeking a way to escape. This ghost of a lake or river is as uneasy when day comes as any other ghost, but by or before ten o'clock it seems to pull itself together and begins to rise upward in scattered flocks or small clouds, reaching up to its kindred, the first clouds that are passing over. It is precisely like a flock of geese rising upward to join other flocks that are calling down to them from above.

The fog forms in the valley at night, just as water would accumulate there if Noah's flood were to come again, but not for the same reason, or under the same law. The water seeks its level, and its level is at the lowest point within reach. The level of the fog is in the stratum of air where the clouds float. Hence, after all, one may say the fog seeks its level also, but it is up and not down. The fog is only a finer rain. It is white because of the air it holds. Its minute particles of water become little balloons inflated with air; it would take thousands of them to make one raindrop. Both rain and fog are the 


\section{NATURE AND NATURAL HISTORY}

result of a chill or a fall in temperature. In these mountain valleys, where the sky is clear and the air still, a fog is pretty sure to form during the night. The colder air flows down into the valley and its moisture is condensed into fog.

Now at a quarter after nine o'clock the fog has become a mere wraith. It is forming a thin, frail stratum above the valley beneath which I can see that the air is clear, save a bluish haze which will linger a little while after all signs of fog have vanished.

The fog in the valley is only the phenomenon of the dew on a different scale. There is no dew on a windy or cloudy night, or during times of drought. Such things set one to thinking about the circuit of the waters - how many forms this element assumes, and how much depends upon it - from the earth to the clouds, through the agency of the sun, from the clouds to the earth in the rains and the dews, from the earth to the sea again through the channels of streams and rivers. On this round it figures in the rainbow, frowns or flushes in the clouds, glances like a diamond in the dewdrop, courses through the cells of plants and trees, and through the heart and veins of man, and of all animal life - terrible in floods and waves, sublime in the great cataracts, a bridal veil in the mountain waterfalls, a magic mirror in placid lakes and rivers, transporting, transforming; a ministering angel at one time, a destroying demon at another, the chief 


\section{FIELD AND STUDY}

builder and shaper of the surface of the globe, and the key to all life that moves upon it. It has been through the heavenly circuit; it has been a breath, a painted cloud, a trembling dewdrop; it has been the lair of the lightning; it has pulsed in the heart of the storm; it has fertilized the hills; it has eroded the rocks; it has been the giver of life and the giver of death.

With the sun at one side and the earth at the other, what a tremendous and, on the whole, beneficent elemental machine is set going! Noiseless, exhaustless, all-powerful, wound up by the primal impulse that set the worlds in motion, it will not run down till the worlds become sterile with the lapse of geologic and astronomic time.

$\S$

Who or what taught the birds, both parents and nestlings, to practice sanitary measures about their nests? The young of all kinds that I know of never defile the nest till they leave it, and the parents are diligent in waiting upon them before that time. No more regular is the opening of the mouth of the young for food than is the movement which indicates to the parent that the refuse of the food is to be disposed of. These sanitary precautions are a part of the primal, fundamental paternal and maternal solicitude over the well-being of living things that pervades all nature. This solicitude keeps the balance of the account on the side of life. 


\section{NATURE AND NATURAL HISTORY}

\section{$\S$}

When we are hard-pressed for an explanation of natural phenomena we fall back upon the nature of things. That is the final court of appeal. We can take no step beyond that. It is a generalization so vast that all the mysteries of creation may be hidden in it. The question of the nature of things is involved in the question of the nature of the human mind that speculates about the nature of things. There is the nature of things, and there is the nature of man. How are the two related? How do they interact? Is not man a part of nature? What is common between a man and a rock, or a man and a river, or a man and a tree, or a man and his horse, or his dog?

The same primary elements and forces are in all, the same chemistry, the same physics. In all vertebrate animals the metabolism is about the same, and the ontogeny and philogeny. Protoplasm is the physical basis of life in both the animal and the vegetable; the cell is the unit of structure, the tree breathes or takes in oxygen through its leaves, as man through his lungs. The sunlight does for the tree what it does not do for the animal; it enables it to appropriate the carbon dioxide from the air. This poisons the animal, but nourishes the plant. Man must get his carbon through his food. The vegetable world stands between him and the mineral. His only direct hold upon the world of non- 


\section{FIELD AND STUDY}

living matter is upon the air through his lungs, and upon the water through his digestive tract. Of all the elements, he gets air alone at first hand; he gets water at first and also at second hand, through the tissues of animals and vegetables. He lives in a sea of nitrogen and he cannot live without this element, but he is powerless to appropriate it from the air, as he is to appropriate hydrogen from water, or iron from the ore.

It is the nature of the oak to produce acorns, of the apple-tree to produce apples. Each after its kind. But what makes the kind - that is the mystery. The same chemical elements, more or less, the same physical processes in an oak and in a maple, the same water, the same soil, the same air nourish both; osmosis, endosmosis, oxidation, hydration, and so on, the same in each; and yet one is an oak, and the other a maple.

You may bring up a dog on the food of a man, and yet you cannot make a man of him. The putrid fungus will grow under the same conditions that nourish a rose. The secret of life with all its myriad forms is hidden in the nature of things, and there we have to leave it. We finally run nearly every question of nature to hole in the nature of things. How our mental and spiritual life share in the nature of things is a hard question.

"Objects gross and the unseen soul are one," says Whitman. Matter and mind blend, but how? 


\section{NATURE AND NATURAL HISTORY}

Nature is so all-inclusive that we cannot say of anything that it is not natural. It may be out of the usual course of things, or contrary to some particular phase of nature, and yet it must be natural. We may say that it is not natural for a butternut-tree to produce hickory-nuts, or a peach-tree to yield pears, yet if such a thing ever happened, it must be natural, because it would be a part of nature. All the reported miracles would fall into the same category of the natural. One species of tree grafted upon another is still a bit of nature, a novelty brought about by the hand of man, as are all our improved fruits and grains. Nature accepts them, but does not guarantee that the seed of the apple will produce a pippin or a Baldwin. In the animal world inheritance is a much more certain factor. Rarely is there a reversion to a more primitive type. Improved grains and flowers breed true, but improved fruits rarely do. Probably the former, if left without man's care, would in time revert to the wild type; all would drop what man has given them and degenerate. Man himself degenerates toward the savage if long enough removed from home and civilization. The dog goes back toward the wolf, and the horse back toward its wild ancestors. What we add to Nature is easily peeled off, but what Nature adds to herself sticks.

$$
\S
$$

The atmosphere clothes the earth miles deep with magic - an invisible, ungraspable presence, bearing 


\section{FIELD AND STUDY}

upon our bodies with a weight of many tons and running by its weight our machinery of life, yet as unfelt as any feather. Our relation to it is so delicate, so constant, so harmonious, so all-embracing, that we are unconscious of it till we turn about and cross-question it. All our major relations to nature are of a similar kind. We do have to take thought about our food and shelter and clothing, but not about breathing or gravity, or the rain, or the sunlight. Through the air, through gravity, through light, through climate, through geology, through astronomy, nature constantly acts upon us. A child in its mother's womb is no closer linked to its mother than we are all our lives to what we call nature. The source of all our strength, namely, gravity, we are all unconscious of, unless we cross it or defy it. Mother Nature carries us in her womb and we know it not till we meet with the new birth of reason. Then we know our mother and see and feel our kinship and sonship towards her. Science opens our eyes to the truth of the facts that the poets and prophets have sung in all ages. We see with our reason what men in all ages have felt in their hearts.

How contrary to Nature man seems! How he crosses her and forces her and masters her, and improves upon her, and makes her his slave, and yet he is also a part of Nature. She is his banker; from her vaults come all his funds. Whence this apparent 
contradiction? Because in man appears something that appears nowhere else in Nature - the gift of reason, or the soul. This turns upon Nature and judges her, and does with her forces what they cannot do with one another.

Man makes new combinations, he links together that which Nature has sundered, and he sunders what Nature has linked together, and gets power through each process. He adds nothing; he has nothing to add; his wit is the new factor. It brings about new situations, it redistributes the natural forces and elements. It uses Nature's mechanics to new ends, it uses Nature's chemistry to make new compounds, it ties them together so delicately that a spark or a blow releases tremendous energy. If Nature did this herself as man does, the sphere would have been blown to atoms long ago. Man controls. He gives the upper hand to one force over another. Nature lets her dogs fight it out, lets the fire rage, lets the floods roar, lets the winds destroy. She has no special end as man has. In the inorganic world her forces seek a deadlock, or a stalemate, but her complex of forces is so vast that an equilibrium is never reached, or is constantly broken up. The waters seek the sea, but cannot stay there. The laws of heat tend to reduce all to a uniform temperature with the death of all life, but this never really comes about. 


\section{FIELD AND STUDY}

\section{$\S$}

One thing is very certain, a certainty that we are constantly forgetting or overlooking, namely, that man is a part of nature, of the sum total of things, and that whatever we affirm or deny of the universe, we affirm or deny of him.

Only this morning I was saying to myself, "There is nothing human in the universe, all is unhuman," when I was brought up by the thought that the whole of humanity is a part of the universe; that man is as much a product of the earth as are the trees and the grass, and his genesis must involve, more or less, all the material forces, geologic and astronomic.

\section{$\S$}

In nature the good and the bad, the beautiful and the ugly are not separated. They are such only to man; all is in keeping with the impersonal laws and forces. We call that evil which thwarts or injures us, but nature is like a cloud that goes through the cycle of change and remains the same. Good and bad are irrelevant questions, just as upper and under do not apply to the orbs in space. To our senses it is all upper, but in reality the terms are meaningless away from the earth.

In nature all is good, but, again, the terms "good" and "bad" are meaningless with the "all." The Cosmos is self-repaired, self-balanced, self-supported, and is all good or all bad, just as you elect. 


\section{NATURE AND NATURAL HISTORY}

We divide and subdivide, and sort, and sift, because we can use only parts and fragments of nature.

One May day on my return from a walk I asked a friend - quoting a line of Emerson's, about "the untaught spring being wise in cowslips and anemones" - which one of our wild flowers showed the most wisdom, at least something most akin to human taste, in showing off its own beauty. After a moment's reflection she said, "The columbine." "Yes, that is it - 'rock-loving columbine,' as Emerson says." It is really the child of the rocks; it must have its rocky throne and background, the delicate, sculptured, flame-colored flower hanging its brilliant tremulous bells above the gray, immobile rocks. In my walk through a field I came upon an inclined rock-stratum cutting up through the turf, and at the foot of it stood groups of columbine set off against the gray background. Along the road in the woods the rocky wall and precipice were fairly aflame with columbine. It came out of narrow seams like jets of flame. Apparently the less soil, the more columbine. It seemed as if the old Silurian rock after millions of years of gestation had hatched out a soul, and this was the expression of it.

\section{"Ten thousand saw I at a glance,}

Tossing their heads in sprightly dance."

Wordsworth's daffodils are coarse and common beside our flower, with its throb of color, its five gold- 


\section{FIELD AND STUDY}

rimmed honey-wells, its five-pointed collar, its cluster of golden anthers, and its delicate foliage and purple stems. It bejewels the rocks; it loves the rocks as the jewel-weed loves water. Our rock corydalis also loves the rocks, but it is a far less highly developed flower and has none of the columbine's art; and the same is true of saxifrage and rock cress - all children of the rocks, but not "wildly wise" and wildly beautiful like the columbine. Aquilegia, - eaglelike, - but its talons are tipped with honey, and its crimson is the glow of the cheek of May. It holds aloft its nectarines like tiny bottles open at the bottom into which the rains cannot enter. Reverse its pendulous character and its grace is gone.

$\mathrm{Ah}$ ! the world-old rocks with these living jewels in their ears - how young they look!

$\S$

Emerson in his "Journals" has a phrase about the "shortcomings of the universe." The excesses of the universe are much more obvious: Nature's overflowing measures, her unloosened forces - the tornado, the avalanche, the earthquake - destroying with one hand what she builded with the other, the devastation of flood and fire; in human history, wars, pestilence, and famine; and, in the history of the lower forms of life, the failure of natural checks and balances - locusts, tent-caterpillars, gypsymoths, lemmings, and the like. But the shortcomings of Nature are not so easily pointed out. Of course, 


\section{NATURE AND NATURAL HISTORY}

both her excesses and her shortcomings are only such from our point of view - the point of view of the petty economies with which our lives are bound up. We measure Nature's excesses and failures by standards of our own. "Who heaps his measure spills his wine," says one of our minor poets, but Nature's wine, though spilled, is not lost. Another cup is ready to catch it. "If my bark sinks ' $t$ is to another sea," sings a Concord poet, but only Nature can say this. Her loss in one sphere is a gain in another. A few years ago the measure of insect-life was overfull; the tent-caterpillars were fast becoming a plague, and the larvæ of other insects were devastating the woods and gardens and fruit-lands. Then came a wet, cold May and the germs of these pests were nipped in the egg; they did not hatch, or, if hatched, they failed to mature; and thus our orchards and forests are greatly the gainers. The insect-eating birds have suffered, but vegetation has profited.

$\S$

The events and characters of history do not appear in ordered sequence any more than they do in nature, or in the physical history of the globe. There are slumps, lapses, delays, waste. The seasons, as we name them, follow one after another, but there are set-backs, cruel frosts, or unseasonable heats, or droughts. Yet the tide of the year sweeps on. The race of man has progressed through blood and crime 


\section{FIELD AND STUDY}

and wars and pestilence and superstition, but it has been an ordered sequence only as we make it so. The creative, ameliorating power is blind, but it is ceaselessly active, and it finds its goal sooner or later. Endless variation, with natural selection working sleeplessly, bring about the new and higher types in animal life. In human progress there is a new element not in nature, namely, human reason, which works in and under the fatality of nature, which has been a great element in human progress, but the tendency to progress is older than human reason.

We might say the steam engine, the cotton-gin, the telegraph, the phonograph, came when they were most needed. We do not see that these things create their own need, that they are a slow evolution, that they came when the general progress of the race was ripe for them. They are a part of our mastery over nature, which is the growth of ages.

The progress of nature and of the race of man is well typified by these cat-tail flags growing here in the ditch in front of my window. The seeds of the plant grow only in marshes, and they always find the marshes. How? They look in all directions north, south, east, west - and hence are sure, sooner or later, to blunder on the spot which they seek. Ten thousand miss the mark to one that hits, but the one does hit it. 


\section{NATURE AND NATURAL HISTORY}

$\S$

The great movements of the Cosmos are on such a scale that we note them not. The sidereal universe is as fluid and mobile as a meadow brook, but to human experience it is as fixed as the everlasting hills. The enormous speed of the revolving earth registers itself to the eye very slowly in the rising sun or moon, while the incredible speed of the stars in their diverse orbits does not register itself to the human eye at all; to our eyes they are fixed forever in their places in the sky; as the earliest observers beheld the constellations, so we behold them, and so untold future generations will behold them, though the separate bodies that are thus grouped are rushing their several ways through space with a velocity that nothing but light rivals.

$\S$

Think of this huge globe as a living corpuscle in the veins of the Infinite, gross and inert to our dull senses, but vibrating and responding to influences and forces that are too vast for us to take in. Behold it floating through a sea of energy like a mote in the air, or a corpuscle in the veins, as insignificant a part of the Whole as the latter is of the human body, but under the spell of the Whole, and a vital part of the Whole. If we could draw far enough away from our system we should see the sun surrounded by his little family, filling a space in the heavens the size of one's hatbrim, and other suns filling other little 


\section{FIELD AND STUDY}

spaces, and still others without end, like daisies here and there in the broad meadows - the vacant spaces are so immense. Or, they are like vessels upon the sea, with a vast waste of waters between. But for all the room, collisions do happen at sea, and collisions, no doubt, do happen in the abysses of sidereal space. Astronomers see evidences of them at times. The meteors that cut through our atmosphere, and the meteoric dust, doubtless have their origin in these collisions; the blazing stars, and the paling stars, the same. The relative space occupied by one system is like the palm of one's hand in one's lap compared with the spread of the Western prairie thousands of miles away. The spaces between the stars in Orion's belt, or in the Pleiades, would open to hundreds of millions of miles, if we could approach them. Like fruit on the same vine seem many groups of stars, but the spaces that really separate them overwhelm the mind that tries to grasp their magnitude.

Ground-room is cheap in heaven; there are oceans of it to spare. The grouping of celestial bodies which we see are as of a flock of birds upon the same branch.

$\S$

I never tire of contemplating the earth as it swims through space. As I near the time when I know these contemplations must cease, it is more and more in my thoughts - its beauty, its wonder, its 


\section{NATURE AND NATURAL HISTORY}

meaning, and the grandeur of the voyage we are making on its surface. The imaginary and hopedfor other world occupies my thoughts very little. There is so much to know here, so much to enjoy, so much to engage every faculty of the mind and develop every power of the body, such beauty, such sublimity, and such a veil of enchantment and mystery over all - how can one ever tire of it, or wish for a better? I am in love with the earth. With all its hostile forces and forbidding features, - its deserts, its jungles, its killing heats and frigid zones, its storms and earthquakes, its wars, and famines, and contagious diseases, - I am thankful that my lot was not cast on any other planet. It is the best possible world, undoubtedly, for such beings as we are, and is slowly becoming better adapted to human life - ripening on the vast sidereal tree whose fruit is worlds and systems. How much it has ripened in the historic period who can tell? No doubt it has ripened somewhat in ten thousand years. But every geologic period has undoubtedly seen some improvement, with temporary set-backs during the ice age, or ice ages. But these ages sculpturing the surface, pulverizing the rocks, and changing the rivers - filling up and wearing down - seem like workmen preparing the landscape for a more abundant harvest. 
$\S$

When, during a recent cold, wet May, I saw the delicate wood warblers perishing for want of food, and, during the dry, hot August that followed, saw the robins dying for the same reason, I said, "Dame Nature takes no thought of her children." It has taken her long geologic ages to develop and perfect them, and then she weans them as a hen weans her chickens, and leaves them to take their chances in the great complex or maelstrom of physical forces that surrounds them. Many are cut off, but enough survive to serve her purpose - the continuance of the race. For the individual, we are in the habit of saying, she cares nothing, her solicitude is only for the race. Tennyson sings this in a striking manner in his "In Memoriam."

"So careful of the type, she seems,

So careless of the single life."

Is it true? Do not the biological laws favor the individual as well as the mass of which he is the unit? In other words, can the race be favored except through its units? Are there any biological laws that apply to the many and not to the one? If it were the mass against the one, the race against the individual, then one might say yes. The multitude has advantages that the one does not possess, but in this case the one is a part of the multitude, as the single soldier is a part of the army. The wise general, of 


\section{NATURE AND NATURAL HISTORY}

course, cares more for his army as a unit than for the individual privates that compose it; he is often obliged to sacrifice many of the soldiers for the safety and well-being of the army; but the care he takes to safeguard the whole applies to every separate unit. In like manner Nature is as solicitous for the individual as she is for the race, but, on the whole, in the battle of life the chances are that the few will fall while the many escape.

True it is Nature does not make a man or a bird, and say, "Now I will look after him, or it; I will temper the wind to the shorn lamb; my special providences will see that no harm befalls this one, or that one." Nothing of the kind. The forethought of what we call God is only the sequence of biological laws which brings about the development of species and leaves them to the fate of the blind but, on the whole, beneficent forces. We have to say that there is an intelligence in nature - an allpervasive mind that gives rise to the vital order which we see, and of which we are a part, and that through the nature of things makes our continuance possible, but it is in no other sense paternal or human. But here is the queer thing: it has made it possible for us to pass this judgment upon it, to be thus critical toward it, to utter the verdict I have been uttering. It is no invention or selection of our own that we are men and have these wonderful bodies and these capacities. 


\section{FIELD AND STUDY}

\section{$\S$}

When one sees the great cosmic processes and the terrestrial forces going on so irrespective of man, so indifferent to him, so hostile to him if for a moment he places himself in wrong relations to them, ready to grind him to powder or engulf him in the deep, - so infinitely slow in providing a place for him, and so indifferent to him when all is done, careering on through countless ages before he comes, and, we may safely say, careering on through countless ages after he has gone, the earth given up to low bestial life for untold æons before man appeared, - when one considers all this, one marvels why he is here at all. Was his advent a mere accident, or is it all for him? In our pride we say it is all for him, and all our theology has been for centuries trying to explain away this apparent hostility or indifference of the natural forces, and to reconcile man's career of pain and suffering with the idea of a benevolent God.

When we consider what infinite pains and time Nature seems to have taken to crown her work with man, it is staggering to see her apparent indifference to each individual of us. Not one smallest force in the universe will make one exception for any of us. We are borne along by this stream of tendency, or creative power, and the stream cannot turn back or be interrupted. Every effect must have its cause, which refers to another cause, and so on. Men are 


\section{NATURE AND NATURAL HISTORY}

nothing with Nature; man is everything. At least, so we flatter ourselves.

Unless we think twice and thrice about this matter, we are likely to exaggerate this apparent indifference toward man on the part of Nature. The inorganic world is certainly indifferent to him and to all other forms of life. The laws of force and matter know him not. But the organic world as certainly favors him; the biologic laws are on his side; else how would he ever have got here, or remained here? I do not mean to say that they make exceptions for him, any more than fire and flood do, but I mean that in their inevitable workings they promote his general welfare. They adapt him to the universe in which he is placed, they have endowed him with a brain which gives him dominion over all animal life and enables him to subdue and use the inorganic forces. The biological forces favored man long before he was man. In what large and bold and striking lines Whitman put this idea in his "Leaves of Grass":-

"Immense have been the preparations for me,

Faithful, and friendly the arms that have help'd me.

“Cycles ferried my cradle, rowing and rowing, like cheerful boatmen,

For room to me stars kept aside in their own rings, They sent influences to look after what was to hold me.

"Before I was born out of my mother generations guided me, My embryo has never been torpid, nothing could overlay it. 


\section{FIELD AND STUDY}

"For it the nebula cohered to an orb,

The long slow strata piled to rest it on,

Vast vegetables gave it sustenance.

Monstrous sauroids transported it in their mouths and deposited it with care.

"All forces have been steadily employ'd to complete and delight me,

Now on this spot I stand with my robust soul."

But we must beware about being too sure about the friendliness of the biological laws. They fail to favor us at least in this respect: the microscopical germs that destroy us are as strictly the work of these laws as we ourselves are. They are real beings lying in wait upon all sides ready to pounce upon us and undo the work of the beneficent germs whenever our guard is down. I do not mean to say that there is any malevolent intention in $\mathrm{Na}$ ture toward us, but that we are now and then the victims of the indiscriminating operation of her laws, in the organic as well as in the inorganic world.

\section{$\S$}

The caterpillar hurriedly crawling about my porch, going this way and that way, changing its course every second or two, lifting up its head and feeling right and left as if searching for some particular object, crossing and recrossing the porch floor, feeling into the cracks, climbing up the vines and creeping to the pendent end of one of the shoots, and then hanging by the tip of its body, then feeling 


\section{NATURE AND NATURAL HISTORY}

out in all directions, and finally letting go its hold and falling to the floor, where it again begins to search till it at last mounts my leg as I sit writing, and appears upon my knee, furnishes a good sample of blind, pushing Nature, radiating in all directions in order to be sure to hit a mark that lies only in one particular direction - in this case, a suitable place or corner in which the insect may weave the shroud in which it is to undergo its metamorphosis, and emerge a winged creature. 


\section{VI \\ MISCELLANEOUS NOTES}

OES your new religion help toward a larger and freer life, toward more good-will and tolerance, toward a keener appreciation of the world in which we are placed, toward a wider outlook and deeper and saner human relations? It will help toward these things just in the degree in which it springs from these things.

$\S$

The lower orders of animals act from impulse, not from thought. The bird builds its nest from impulse, incubates from impulse or inherited disposition, migrates from impulse, and weans its young from impulse. Man acts from both impulse and thought. He thinks about his acts. Thought in him governs or controls impulse. He has an impulse to wed and breed, but he stops to think about it, and to plan for it. The sexual instinct sometimes masters him and he assaults the female like a brute animal, but on the whole he keeps it under control. The migrating impulse is strong in man as in other animals, but is more or less controlled. It is strong in the spring, but judgment often makes him wait till summer or fall to satisfy it.

The impulse of fear often masters the lower 320 


\section{MISCELLANEOUS NOTES}

animal and he runs away. The impulse of anger and revenge often masters him. In all these things the animal lets himself go; there is no restraining influence of mind or judgment.

\section{$\S$}

Was Epictetus logical when he compared logic to a measure in which we measure corn or other grain? A bushel measure is an arbitrary standard agreed upon by the community using it; any other standard agreed upon would be as fair and just. But logic is not an arbitrary standard, that we could change at will; it is based upon the laws of the human mind. You cannot standardize vital things, only mechanical things. He is more logical when he says that to be blind in the reason, which distinguishes good from evil, is like being blind in the vision, that distinguishes white from black.

$\S$

What a sneaking admiration many Americans have for a monarchical form of government! It is a nice thing to look at; it is picturesque, - a permanent head to the State, grading down through various ranks to the masses. It appeals to a feeling we all have. Royalty! What a magic word! Magic because the race has been so long under its sway. I love to see the bees in the hive surround the queen and make obeisance to her. They never turn their backs to her, they seem loath to touch her except to feed her. She will not feed herself; and she will fight only 


\section{FIELD AND STUDY}

with royalty. Yet she is in no strict sense a queen. She is the mother of the hive, and the reverence of the bees is to motherhood.

A democracy is far less pleasing to look upon than an autocracy, less artistic, less architectural. A monarchy is like a cathedral, a democracy like a country church. Democracy is science; many illusions are gone. Monarchy is literature; and art, illusions, and superstitions remain. Science and Democracy are now in the ascendant. Will they always remain so? Undoubtedly human life will adjust itself to them.

$\S$

We know the sparks in the fire are minute particles of combustible matter, and that this matter is quickly consumed or transformed into other forms of energy. The sparks from an electric battery are of another kind, they are not matter, there is no combustion there. So far as we know they are pure discarnate energy. The whole material world, visible and invisible, appears to be charged with this energy which man can summon forth at will. Is it transcendental matter?

$\S$

At times I have very serious misgivings about the outcome of the world war. I fear we are reaping what we have sown, and that we have sown the wind to reap the whirlwind. For a hundred years or more all civilized peoples have been striving for 


\section{MISCELLANEOUS NOTES}

material efficiency, for power to rule the world of material forces. We have cultivated science as if it were our salvation; we have builded upon it and followed it eagerly wherever it has led, and it has led us to new conquests on all sides. We have all been part of a world movement for world power. The gods we have really worshiped have been and are the gods of material things. In this movement Germany has led all other nations. Its fullest flowering and fruit have been with her. She has gone soul and body to efficiency on this low plane. She is drunk with the wine of her own material prosperity. The Darwinian principle of the struggle and the survival of the fittest has become the corner-stone of Germany's philosophy of national life. In brute strength and the will to conquer she leads. And it has looked at times as if she might dominate the world and impose her Kultur upon us all. The gods of science are on her side, but the gods of the moral law are on the side of the Allies and I cannot believe they will give world dominion into her hands. If they should, then good-bye to that spirit that has made France and Italy and England what they are, and that has made America what she is, the spirit of freedom, of justice, of ideal values, - our blended inheritance from Greece and Judea and the meditative Orient, - the spirit that begat literature, poesy, art, music. The later generations of Germans have produced nothing better or higher than Krupp 


\section{FIELD AND STUDY}

guns. If a Germanized world should come, it would be the result of a movement that we have all been partners in.

\section{$\S$}

A born prophet and leader of men always makes or finds a following and starts a new era. When an age is ripe for a change a leader is sure to appear. He is begotten by the spirit of the times. Such men as Washington, Lincoln, Grant, Roosevelt, Wilson, were evoked by the spirit of the times in which they lived; they were an evolution.

Human affairs differ from cosmic affairs or the affairs of nature in this respect: in human affairs there enters a new element not operative in nature - the element of reason. Reason cuts across lots, saves waste, improves the means, and gets there ahead of nature. Man's progress has gone on faster and faster as his reason has developed more and more. No doubt every age has men that could lead it to victory if the demand arose. But the age is not ripe for them. There is more or less latent greatness in every age, greatness that is never developed; just as there is a vast amount of latent heroism in the people about us, as is proved when circumstances arise to call it out.

\section{$\S$}

Lover as I am of the warmth and the light, yet at times I almost rebel at the glare of midday. How prosy life seems then compared with the feeling of 


\section{MISCELLANEOUS NOTES}

the morning and the evening! The vertical flood of light is merciless. It kills all illusion. It emphasizes the hard reality. It strips the landscape of its glamour. Romance flees away; the shy spirits seek the shade; the songbirds become silent; love-making of both man and beast declines; the pitiless glare halts even the turtles and the frogs. Have we not been told of certain French authors who turn day into night because their imaginations work better by lamplight than by sunlight?

Our fears, our superstitions, our disquieting thoughts are more active by night than by day. Death seems nearer. Your own illness, or that of one in your family, seems much more portentous in the darkness. When the sun comes half your apprehensions flee away. The terrors of a storm by night are augmented fourfold. Scenes that at such times are strange and exciting to the imagination are dull and commonplace enough by daylight. Hobgoblins never venture abroad except at night. Night is the land of fable, of myth, of superstition, of evil thoughts and deeds, of plotting and conspiracies. If the night were cut out, how would crime diminish! How much less startling and ominous the knocking at the gate in "Macbeth" would seem at noon than at midnight!

The noonday glare does put the imagination out of countenance; it puts all the evil spirits to flight, and our direful apprehensions fade away. Romance 


\section{FIELD AND STUDY}

is shy of it, and many other things. But how it does ripen the fruit and the grain! How it brings us to ourselves and the common-sense view of things! how it favors our practical lives! how it grounds us in real things!

The best thing about the night is that it gives us the stars; the best thing about the day is that it gives us the earth and the sky - all the wealth of color and all the beauty of form; the bow in the clouds, the clouds themselves, the lakes, the rivers, the green earth, the lofty peaks. Night gives us infinity, it gives us the awful grandeur and mystery of the heavens, but the day makes us at home in the earth and fosters the understanding. We love the sunlit fields, but we stand in awe of the starlit heavens. The middle ground, the twilight, favors sentiment and memory and romance. Why is the evening twilight more enticing than the morning twilight?

$\S$

How much more valuable is an instinct for the truth than any one special gift or talent! One sees men of superior mental equipment who are yet lacking in this instinct for the truth: that is, they do not gravitate naturally, spontaneously, to that which is true, as distinguished from that which is merely plausible or specious or expedient. I was thinking of this recently while reading Darwin. How single his mind was! In debate most men are 


\section{MISCELLANEOUS NOTES}

more intent on victory than upon the truth. Hence it is that the truth is so often imperiled by controversy.

"What more absurd than to quarrel with a man because he does not see as you do!" I often hear this remark made in defense or excuse of the naturefaker. Now the whole question hinges upon what is meant by the word "see." If you mean "think," then I quite agree with you; all men do not think alike; they differ as much in this respect as they do in their complexions, or stature, or dispositions. But if you refer to the use of the corporeal eye, actual observation of external objects, then I say all men must see alike if they are to see accurately.

$\S$

St. Augustine says we cannot see darkness, nor hear silence, but is it not our eyes and ears that make us aware that such realities exist? There are many problems and mysteries which our reason cannot solve, but is it not the reason that discloses such questions to us? Reason has its limits, and it is never more triumphant than when it recognizes these limitations.

\section{$\S$}

"What is it that constitutes and makes man what he is?" asks Huxley, and answers, "What is it but the power of language?" One may say with equal confidence that it is man that makes the language. 


\section{FIELD AND STUDY}

Man is first and the language follows. You must have man before you can have his language. The lower animals have a rude language, but it does not develop them, or make men of them.

$\S$

There seems to be the same excess of fear in the world that there is of pain. How fearful most of the wild creatures are! and for reasons. Fear is necessary to their self-preservation, hence Nature heaps the measure. An animal is as afraid of a harmless thing as of a dangerous. A horse is as afraid of an automobile as of a bear. Nature secures her end when she makes the animal afraid of anything and everything strange and unusual. She wastes no time in giving the animal the power to discriminate: an excess of fear can do no harm, and it may do good. To trim and curtail and economize is not Nature's way. She sows her seed broadcast, sure that some of them will take.

Fear in the child is, in our day, for the most part gratuitous. It is, of course, a survival from our animal or savage ancestors. There was a time when the dark concealed a real foe, and when the strange apparition meant harm or death. The warring of the male animals over the females is wise; the strongest propagates the species, but see the pain and suffering that attend it, often death. What does Nature care? Her ends are secured. Natural selection is a painful and expensive process, but it goes. 


\section{MISCELLANEOUS NOTES}

$\S$

We think of this mystery we call life under the image of a fluid; it may take any or all forms; it is a stream which is ever and never the same; it begins and ends every moment; it adapts itself to all conditions, in the air, in the water, in the soil, on the rocks, in the surf, in the marsh, in the cold, in the heat - form within form, form nourishing form and destroying form, life building up, life pulling down, life changing the face of the earth. The primal laws of hunger, of feeding and breeding, shape all the rest. To get food and a place to increase and multiply is the source of all the "red strife" and all the "white strife" in the world. These are the mainsprings of development. And are they not beneficent laws or instincts? Do not pleasure and well-being flow from them?

\section{$\S$}

To know one's own mind on any of the great questions of life, to know one's own ignorance, to understand one's want of understanding, to know the part played in one's mental life by race, family, training, by "previous condition of servitude" to creeds and parties and half-views, by the times in which one lives, by ancestry, by temperament, by schooling, and by surroundings, is a very great matter. Each of us is a composite personality; behind us is an immensely long line of ancestors of all types and conditions, each of whom has contributed some 


\section{FIELD AND STUDY}

shred of character to our make-up, and each of whom speaks more or less in all our daily thoughts and acts. No wonder we are contradictory and inconsistent. No wonder we do not hold steadily to one set of views on any great question. Now one of our ancestors dominates us, now another. Is it at all likely that all these ancestors held the same views on all subjects? Did they not burn and hang and persecute one ancther for opinion's sake?

THE END 
INDEX 



\section{INDEX}

Air, mineral elements in, 123, 124; our relation to the, 303,304 . Air-plants, 123, 124.

Animals, ebb and flow in lives of, 152; specialized and generalized forms, 162; do not reflect, 293. Antennaria, 210-13.

Apple-tree, 39, 40.

Aristotle, quoted, 112.

Art, and reality, 236-40.

Astronomy, pleasures of, 190, 191.

Atmospheric pressure, 271 .

Atoms, 263.

Autumn morning, 297.

Barnacle, 273.

Beard, Dan, his Animal Book, 292, 293.

Bee, honey, 138.

Bee, mason, 137.

Beebe, C. William, quoted, 294.

Bees, mind in, 137.

Beginnings, 189, 190, 244.

Birches, growing on rocks, 36,37 .

Birds, migration, 3-22; effects of a late spring upon, 15-17; our interest in, 53,54 ; leaving the nest, $61,62,72-76$; use of white materials in nest, 71,72 ; songs, $89-$ 101; courtship, 89, 90; opposite natures of the sexes, 95; affection for young and mate, 98,99 ; eyesight, 103, 104; winter waifs, 20609, 214-17; sanitation, 300 .

Bird's-nesting, 102-11.

Bluebird, 99, 103; a quarrel with robins, 66, 67; young leaving nest, 73, 74, 76; and wrens, 8082 ; notes and manners, 96 ; virtues, 289, 290.

Bobolink, 7; decrease and increase, 22 ; song and the female, 94 ; nesting, 111; two males and one female, 111.

Bob-white. See Quail.

Boulders, 180.

Brain, the, 266-68.
Bryant, William Cullen, 6, 222; quoted, 5,6 .

Burdock, 33-36.

Butterfly, swallow-tailed, transformation, 44-48.

Buzzard, turkey, 91, 103, 104.

Catalysis, 186.

Catbird, a tame pair, 8.

Caterpillars, transformation and cocoon-weaving, 44-52, 318, 319.

Cat-tail, 37.

Cattle, grazing in water, 274; goring rescuers, 295.

Cedar-bird. See Waxwing, cedar.

Celestial mechanics, 253-55.

Chat, yellow-breasted, a pair with nest and eggs, 62-64; shyness, 64 ; location of nest, 64 .

Chemical affinity, 261, 262.

Chemistry, wonders of, 184-88.

Chickadee, nesting, 110.

Childs, John Lewis, 153.

Chipmunk, 158; washing his face, 115 ; attractiveness, 140 ; boyhood recollections, 140, 141; tidiness, 142 ; friendly ways, 142 ; provident habits, 143,144 ; robbing one another, 144-50; nest, 148; tunnels, 149 ; disposal of earth, 150, 151, 197; varying abundance, 152, 153.

Church, the, 246.

Clematis, 38,39 .

Columbine, 307, 308.

Consciousness, 268.

Coon. See Raccoon.

Cordaites costatus, 181.

Corydalis, 308.

Cosmos, the, 254, 255; great movement of, 311.

Cowbird, experiment with a young one, 59-61.

Creative energy, 259.

Creeper, brown, 216.

Cretaceous period, 260, 261.

Crow, character and manners, 118 21. 


\section{INDEX}

Cuckoo, 55.

Cuckoo, black-billed, feediug young, 196; nesting-habits, 197.

Darwin, Charles, 129, 277; quoted, 278.

Day, and night, 324-26.

Democracy, 322.

Dickcissel, 154.

Disintegration, 186-88.

Dock, yellow, 35, 36 .

Dogs, 114; their capacity for loving, 205; companionship, 205, 206; enjoyments and interests, 206.

Dove, mourning, nest, 14.

Ducks, migrating, 5 .

Earth, the, a celestial body, 243; rotation, 255; growth, 258-61; beauty and wonder of, 312,313 .

Emerson, Ralph Waldo, 17, 113; quoted, $27,28,215,224,235,246$, $248,250,307,308$; and natural history, 221,222 ; a poet, prophet, and critic, not a purcly literary man; his "Brahma," 250.

Energy, 264, 322.

Epicteıนus, 321.

Everlasting, early, 210-13.

Evolution, a hard road to travel, 273; variation the main factor, 273,274 ; speed, 276,277 ; belief in, 277; and ethics, 281-84; the push of development, 284, 285; order of development, 286-88.

Eyes, 51.

Fabre, Jean Henri, on a caterpillar building its cocoon, 48, 49; his studies in insect behavior, 129$39,202-04$.

Fear, 328.

Fern, walking, 39 .

Finch, purple, eating cherry-blossoms, $25,26$.

Fishes, deep-sea, 270-72.

Flicker, or high-hole, drumming, 19; call, 19, 20; nesting, 20, 191; coloration, 21.

Flycatcher, crested, 168.

Flycatcher, olive-sided, 25.

Fog, 297-93.

Fcsil, a, 151.
Fox, red, 31, 32, 197; tracks, 209; two tame foxes, 292, 293.

Geology, pleasures of, 177-83.

Georgia, granite in, 178-80.

Germany, 323.

Glaciers, local, 182.

God, and Nature, 241, 247-51; and evil, 248, 249.

Goldfinch, 152; nest, 105-07; a curious experience with nest and young, 106, 107.

Granite, Northern and Southern, 178-80.

Grass, seed-dispersal, 37, 38.

Grosbeak, rose-breasted, 11; with young, 109.

Grouse, ruffed, 155.

Hawk, marsh, 163, 164.

Hawk, pigeon, 165.

Hawk, red-tailed, 163, 164.

Hawk, sparrow, 165, 166.

Hen-hawk, 163, 164.

Heredity, 329, 330.

High-hole. See Flicker.

History, sequence of events in, 309 , 310.

Hummingbird, ruby-throated, 16, 17,75 .

Humphrey, Miss Grace, quoted, 47. 48.

Huxley, Thomas H., quoted, 327.

Ibis, wood, 294, 295.

Impulse, 320, 321 .

Insects, mind in, 129-39, 204; our interest in books on, 201-03.

Interesting, the, 196.

Jay, blue, migrating, 18, 19; egging expeditions, 67 .

Junco, with nests, 108, 109.

Kingbird, flight, 25; nest, 102, 103 , 106; fly-catching, 102, 103, 195; contrasted with the crested flycatcher, 168.

Kinglet, ruby-crowned, 6.

Language, 327, 323.

Lark, prairie horned, 154.

Leaders, 324. 


\section{INDEX}

Leaf-roller, 138.

Leaves, a large crop of, 40 .

Life, infinitely various, 158; hand in hand with death, 186,187 ; beginnings, 189, 190; development, 259,260 ; and chemical affinity, 261,262 ; the physico-chemical and psychic explanations of, 269 , 270 ; a battle and a festival, 280; the fire of, 284; incalculable and mysterious, 285, 286; a fluid, 329.

Light, invisible, 256.

Lightning, freaks of, 42-44, 124.

Literature and science, 235; and reality, 235-40.

Logic, 321.

Longevity, 296, 297.

Loosestrife, purple, 38.

Loveman, Robert, 223.

Lynx, Canada, cry, 125-28.

Man, and the balance of nature, 157; a generalized form of life, 162,163 ; origin, $243,246,247$; a part of nature, $249-51$; less religious and artistic, more practical and scientific, than formerly, 257, 258; evolution, 260, 274-76; the price he pays for his gift of reason, 291, 292; his relation to nature, 304-06; progress of, 309, 310 ; nature's indifference toward, 316-18.

Micro-organisms, constructive and destructive, 186-90.

Might, and right, 280-84.

Milton, John, 233.

Mind, and the brain, 266-68.

Molecular astion, 256, 257.

Molecules, 263.

Monarchical government, 321, 322 .

Moth, Halictus, 139.

Moths, cocoons, 50.

Motion, relativity of, $264,265$.

Mt. Rubidoux, 180.

Mouse, meadow, 41, 115.

Muscles, 287.

Muskrat, carrying dry leaves, 116.

Natural history, interesting and uninteresting, 193; and the poets, 221-23.
Nature, our interest in, 27-30, 121, 122; uniformity and capriciousness, 40, 42; complete in small things, 112, 113; "jokes" of, 113, 114,117 ; the open book of, 121 ; surprises of, 124 ; ebb and flow in, 152-57; man and the balance of, 157; the approach to, 176; near home, 213-18; relation to God, $241,242,247-51$; change of attitude toward, $244-46$; and science, 252, 253; of things, 301,302 ; allinclusive, 303 ; man's relation to, 304-06; no good or bad in, 306; shortcomings and excesses, 308, 309 ; sequence of events in, 309 , 310 ; her solicitude for the individual, 314,315 ; her apparent indifference toward man, 316-18; pushing blindly, 318, 319.

Nature of things, 301,302 .

Need, 284, 285.

Night, and day, 324-26.

Nitrogen, 185, 262, 263.

Nuthatch, red-breasted, a winter guest, 22-24, 207, 208.

Nuthatch, white-breasted, 208; coloration and habits, 216, 217.

Nuthatches, 10, 160; manners, 23, 207; notes, 24, 207.

Ocean, the, 265.

Oriole, Baltimore, 9, 17.

Osborn, Henry Fairfield, his Men of the Old Stone Age, 281, 283.

Oven-bird, with nest and young, 65.

Oxygen, 263.

Peckham, George and Elizabeth, 129.

Pelican, brown, 113, 114.

Pennsylvania, 182, 183.

Perry, Bliss, his Life of Whitman, 225-27.

Pewee, wood, nest, 105, 167; contrasted with the phœbe, 166,167 ; notes, 166.

Phœbe, and wren, 79; contrasted with the wood pewee, 166, 167; notes, 166; nest, 167.

Photography, and painting, 236, 238. 


\section{INDEX}

Physics, reveals the spiritual side of matter, 191, 192.

Pigeon, passenger, migrating armies, 3-5; last seen, 4.

Poets, and nature, 221-23.

Psychic life, origin of, 266.

Puffin, 113.

Puma, cry, 126.

Quail, or bob-white, 154, 155.

Rabbit, 156.

Raccoon, 30, 197; rooting stones, 295.

Raspberry, black, 39 .

Realism, 237-40.

Reason, 266, 324, 327.

Redpoll, yellow. See Warbler, yellow palm.

Redstart, 15; gymnastics, 8, 9 .

Religion, and science, 242,243 ; tendency and source, 320 .

Reproduction, 277, 278.

Right, and might, 280-84; and wrong, 282.

Riverside, Cal., 180.

Robin, 17, 98, 280; a quarrel with bluebirds, 66, 67; attacking a jay, 67; use of white materials in nest, 71.

Rodents, diversity amid unity among, 161, 162.

Roosevelt, Theodore, 297.

St. Augustine, 327.

St. Francis of Assisi, 88.

St. John's River, Florida, 274.

Sapsucker, yellow-bellied, drumming, 97.

Science, pleasure in, 174-77; and literature, 235; and religion, 242 , 243 ; and love of nature, $252,253$.

Sea-robin, 294.

Sea squirt, 273.

Seals, intelligence, 293, 294.

Seeds, various methods of dispersal, 33-39.

Seeing, 327.

Seton, Ernest Thompson, 31.

Skunk, 31, 156.

Snake, garter, amusing behavior, $116,117$.

Snow, tracks in, 209, 242.
Sparks, 322.

Sparrow, chipping, nest, 106; contrasted with the field sparrow, 172, 173; song, 172; nest-building, 194.

Sparrow, English, 280.

Sparrow, field, or bush sparrow, contrasted with the chipping sparrow, 172, 173; song, 172, 173; nest, 173 .

Sparrow, fox, 18; strange conduct of a bird in an aviary, 86-88.

Sparrow, Savannah, 60.

Sparrow, song, 7, 92, 93; nests, 5558,104 ; a fussy mother, 56-58; contrasted with the vesper sparrow, 168-72; songs, 169-71, 289; nest, 172.

Sparrow, vesper, singing, 97 ; contrasted with the song sparrow, 168-72; song, 171; nest, 171, 172. Sparrow, white-crowned, 18.

Sparrow, white-throated, 18.

Spider, jumping, 51.

Spiders, eyes, 51 ; cocoons and eggs, 51, 52; wisdom and stupidity, 139.

Spring, a backward, 14-17.

Squirrel, flying, 156.

Squirrel, gray, 156, 159, 195.

Squirrel, red, $156,157,159,195,197$, 198.

Stone Mountain, 179.

Stork, 91.

Style, 233-35.

Swallow, barn, 75; pleasing ways, 198, 199; nesting-habits, 199, 200; notes, 199, 200; and the cat, 201; feeding young, 201.

Swallow, cliff, 194.

Swans, in flight, 6.

Symonds, John Addington, on Whit$\operatorname{man}, 227$.

Tanager, scarlet, 10, 11, 55; song, 93; rival singers, 100 .

Temple, Sir William, 296.

Tennyson, Alfred, quoted, 7, 241, 314.

Tertiary period, 261.

Thoreau, Henry D., his Journal, 193; his description of the battle of the ants, 193.

Thorn, red, 39, 40. 


\section{INDEX}

Thrush, hermit, 110.

Thrush, wood, a pair and their nest, 68-71; young leaving nest, 74, 75 .

Time, future, 253.

Tody, 113.

Tracks, in snow, 209, 242; of the Eternal, 242.

Trowbridge, John Townsend, 167, 222.

Truth, 326, 327.

Universe, the, great movements, 311 ; vast spaces, 311,312 .

Variation, 273, 274, 278, 279.

Vireo, red-eyed, feeding-habits, 9; song, 98; and nest, 104, 105.

Vireo, yellow-throated, nest, 71, 72.

Vireos, nests, 71, 105.

Virgil, 233.

Vital force, 188, 189.

Vitalism, 284.

Vulture, turkey. See Buzzard, turkey.

War, the world, 322-24.

Warbler, bay-breasted, 15 .

Warbler, Blackburnian, 10, 15.

Warbler, black-poll, song, 7.

Warbler, Canadian, 12, 15.

Warbler, golden-winged, a pair and their nest, 58-60.

Warbler, Kentucky, feeding-habits, 9.

Warbler, magnolia, 16.

Warbler, myrtle, 9, 11, 16.

Warbler, Wilson's, 9.

Warbler, yellow palm, or yellow redpoll, $1,11$.

Warblers, effects of a cold spring upon, 15-17; migration wave of, 21; the May visitation, $54,55$.
Wasp, Ammophila, 136.

Wasp, Cerceris, 136.

Wasp, Sphex, 136, 204.

Wasps, intelligence of, 131-36, 138, 203,204 ; bluffing of the male, 290 , 291.

Water, circuit of, 299, 300.

Water-thrush, northern, 6.

Waxwing, cedar, 96; nesting, 104, 105.

Weasel, 155, 279, 280.

West Virginia, 182.

Whirl winds, 112.

Whitman, Walt, 222, 255; quoted, $29,94,226,229,230,254,317$, 318; Bliss Perry's biography, 22527 ; his main characteristics, 22528 ; compared with Wordsworth, 228-32.

Whittier, John Greenleaf, 226.

Woodchuck, 30, 156, 158, 194, 197.

Woodpecker, downy, 24, 50, 160, 208.

Woodpecker, yellow-bellied. See Sapsucker.

Woodpeckers, drumming, 97.

Wordsworth, William, compared with Walt Whitman, 228-32; quoted, $245,246,307$; attitude toward Nature, 245.

Wren, house, young leaving nest, 75; restless energy, 77, 78; songs and other notes, 77-79; cock nests, $78,83,86,117$; hostility of other birds towards, 79; quarrel with bluebirds, 80-82; sham battles, 83 , 84; nesting, 84-86; a tame pair, $85,86,88$.

Wren, marsh, cock nests, 117.

Wren, winter, song, 78, 79.

Writing, the secret of good, 223,224 , 240. 
(cbe rituctidide prest

CAMBRIDGE - MASSACHUSETTS

U . S . A 






\section{COLONIAL BOOK SERVICE}

23 EAST 4th STREET

NEW YORK CITY $3, N$. Y.

We Hunt Out-of-Print Books 
North Carolina State

QH81.B97

FIELD AND STUDY

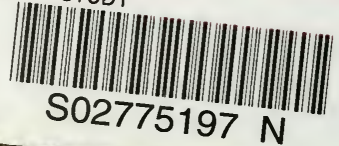

